\title{
Fluorous mixture synthesis of (-)-dictyostatin and three stereoisomers
}

\author{
Yoshikazu Fukui, Arndt M. Brückner, Youseung Shin and Dennis P. Curran* \\ Department of Chemistry, University of Pittsburgh \\ Pittsburgh, PA, USA 15260
}

\section{Supporting Information}

\section{Table of Contents}

$\begin{array}{cc}\text { General Experimental Information } & 2 \\ \text { Experimental Procedures } & 2 \\ \text { Premix stage } & 2 \\ \text { Mixture stage } & 15 \\ \text { Demixing } & 44 \\ \text { Postmix stage } & 44 \\ \text { Copies of key spectra } & 51\end{array}$


General. $\mathrm{Et}_{2} \mathrm{O}$ and $\mathrm{THF}$ were distilled from sodium. $\mathrm{CH}_{2} \mathrm{Cl}_{2}$ was distilled from $\mathrm{CaH}_{2}$. Commercially available reagents were used as received from the supplier. Reactions were monitored by thin layer chromatography (TLC) using Kieselgel $60 \mathrm{~F}_{254}$ silica gel plates. Flash chromatography was performed over silica gel 60, 230-400 mesh, with the designated solvents. ${ }^{1} \mathrm{H}$ NMR and ${ }^{13} \mathrm{C}$ NMR spectra were recorded on Burker DPX-300 or DPX-500 spectrometers using residual solvent peaks as an internal standard: $\mathrm{CDCl}_{3} 7.26 \mathrm{ppm}\left({ }^{1} \mathrm{H} \mathrm{NMR}\right), 77.0 \mathrm{ppm}\left({ }^{13} \mathrm{C}\right.$ NMR). Chemical shifts are reported in ppm ( $\delta)$ downfield from tetramethylsilane and proton-proton coupling constants $(J)$ in Hz. Infrared spectra (IR) were recorded with ATI Mattson Genesis Series FTIR spectrometer and are reported in reciprocal centimeter $\left(\mathrm{cm}^{-1}\right)$. Optical rotations were measured with Perkin-Elmer 241 digital polarimeter with a sodium lamp at ambient temperature and are reported as follows: $[\alpha]_{\mathrm{D}}(c=\mathrm{g} / 100 \mathrm{~mL})$. Low and high-resolution mass spectra were obtained on a VG 70-G or Micromass Autospec double focusing instrument using EI, ESI or CI.

\section{(7S)-12,12,13,13,14,14,14-Heptafluoro-9,9-diisopropyl-2,2,3,3-tetramethyl-7-[(1R)-1-} methylprop-2-enyl]-4,8-dioxa-3,9-disilatetradecane 10a:

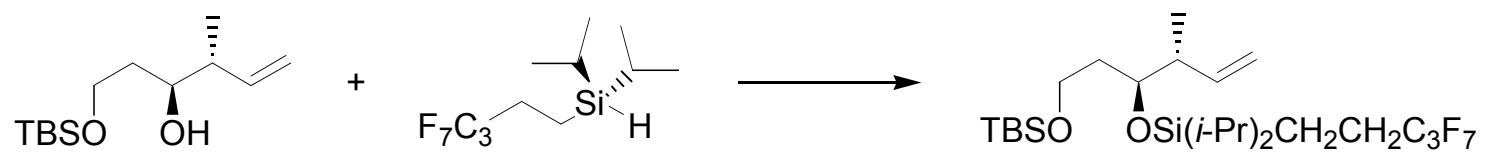

To $\mathrm{C}_{3} \mathrm{~F}_{7} \mathrm{CH}_{2} \mathrm{CH}_{2}(i-\mathrm{Pr})_{2} \mathrm{SiH}^{1}$ (12.7 g, $\left.40.7 \mathrm{mmol}\right)$ was added trifluoromethanesulfonic acid (3.2 $\mathrm{mL}, 36 \mathrm{mmol}$ ) at $0{ }^{\circ} \mathrm{C}$. The reaction mixture was then stirred at room temperature for $13 \mathrm{~h}$. The mixture was cooled to $-30{ }^{\circ} \mathrm{C}$. A solution of the alcohol ${ }^{2}$ (7.65 g, $\left.31.3 \mathrm{mmol}\right)$ and 2,6-lutidine (6.71 g, $62.6 \mathrm{mmol})$ in $80 \mathrm{~mL}$ dry $\mathrm{CH}_{2} \mathrm{Cl}_{2}$ was added dropwise within $20 \mathrm{~min}$ to the cooled mixture. After stirring the reaction mixture for $30 \mathrm{~min}$ at $0{ }^{\circ} \mathrm{C}$, phosphate buffer $\mathrm{pH} 7(150 \mathrm{~mL})$

\footnotetext{
1 The fluorous silanes are commercially available from Fluorous Technologies Inc.

2 White, J. D.; Hong, J.; Robarge, L. A. J. Org. Chem. 1999, 64, 6206-6216.
} 
was added. The phases were separated and the aqueous phase was extracted with $\mathrm{CH}_{2} \mathrm{Cl}_{2}$ and diethylether. All organic phases were washed with brine, dried over $\mathrm{MgSO}_{4}$, and concentrated under reduced pressure. The residue was purified by flash chromatography. Excess silane was eluted with hexanes. The tagged alcohol 10a (15.3 g, 88\%) was eluted with a gradient $\mathrm{CH}_{2} \mathrm{Cl}_{2} /$ hexanes 4:96 to $\mathrm{CH}_{2} \mathrm{Cl}_{2} /$ hexanes $1: 10$. [ $\left.\alpha\right]_{\mathrm{D}}{ }^{20}-5.4$ (c 1.1, $\mathrm{CHCl}_{3}$ ); IR (neat) 2956, 2869, 1464, 1353, 1228, 1182, 1111, 999, 950, 909, 886, 835, 776, $748 \mathrm{~cm}^{-1} ;{ }^{1} \mathrm{H}$ NMR (300 MHz, $\left.\mathrm{CDCl}_{3}\right) \delta 5.81-5.70(\mathrm{~m}, 1 \mathrm{H}), 5.04(\mathrm{~s}, 1 \mathrm{H}), 4.99(\mathrm{~d}, J=7.2 \mathrm{~Hz}, 1 \mathrm{H}), 3.94(\mathrm{~m}, 1 \mathrm{H}), 3.64(\mathrm{t}, J=6.4$ $\mathrm{Hz}, 2 \mathrm{H}), 2.34(\mathrm{~m}, 1 \mathrm{H}), 2.11(\mathrm{~m}, 2 \mathrm{H}), 1.64-1.57(\mathrm{~m}, 2 \mathrm{H}), 1.15-0.79(\mathrm{~m}, 28 \mathrm{H}), 0.02(\mathrm{~s}, 6 \mathrm{H}) ;{ }^{13} \mathrm{C}$ $\operatorname{NMR}\left(75 \mathrm{MHz}, \mathrm{CDCl}_{3}\right) \delta 140.3,114.8,73.2,59.8,43.1,36.6,25.9(3 \mathrm{C}), 25.4\left(\mathrm{t}, J_{\mathrm{FC}}=23 \mathrm{~Hz}\right)$, 18.8, 17.7 (4C), 14.8, 13.1, 13.0, 0.9, $-5.4 \dot{3}^{3}{ }^{19} \mathrm{~F}$ NMR (282 $\left.\mathrm{MHz}, \mathrm{CDCl}_{3}\right) \delta-79.5(3 \mathrm{~F}),-116.3$ (2F), -126.5 (2F); MS (EI) m/z $511\left[\mathrm{M}-\mathrm{C}_{3} \mathrm{H}_{7}\right]^{+}$; HRMS (EI) calcd for $\mathrm{C}_{21} \mathrm{H}_{38} \mathrm{O}_{2} \mathrm{~F}_{7} \mathrm{Si}_{2}[\mathrm{M}-$ $\left.\mathrm{C}_{3} \mathrm{H}_{7}\right]^{+}$511.2299, found 511.2333.

(7R)-12,12,13,13,14,14,15,15,15-Nonafluoro-9,9-diisopropyl-2,2,3,3-tetramethyl-7-[(1S)-1-m ethylprop-2-enyl]-4,8-dioxa-3,9-disilapentadecane 10b:

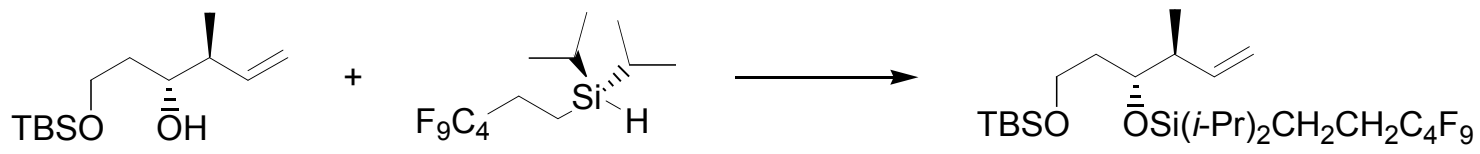

To $\mathrm{C}_{4} \mathrm{~F}_{9} \mathrm{CH}_{2} \mathrm{CH}_{2}(i-\mathrm{Pr})_{2} \mathrm{SiH}(19.0 \mathrm{~g}, 52.4 \mathrm{mmol})$ was added trifluoromethanesulfonic acid (4.1 $\mathrm{mL}, 46 \mathrm{mmol})$ at $0{ }^{\circ} \mathrm{C}$. The reaction mixture was then stirred at room temperature for $48 \mathrm{~h}$. The mixture was cooled to $-30{ }^{\circ} \mathrm{C}$. A solution of the alcohol ${ }^{4}$ (9.86 g, $\left.40.3 \mathrm{mmol}\right)$ and 2,6-lutidine (8.64 $\mathrm{g}, 80.6 \mathrm{mmol}$ ) in $80 \mathrm{~mL}$ dry $\mathrm{CH}_{2} \mathrm{Cl}_{2}$ was added dropwise within $20 \mathrm{~min}$ to the cooled mixture. After stirring the reaction mixture for 45 min at $0{ }^{\circ} \mathrm{C}$, phosphate buffer $\mathrm{pH} 7(100 \mathrm{~mL})$ was added. The phases were separated and the aqueous phase was extracted with $\mathrm{CH}_{2} \mathrm{Cl}_{2}$ and

\footnotetext{
${ }^{3}$ Fluorine bearing carbons give rise to multiplets in ${ }^{13} \mathrm{C}$ NMR. If not reported the multiplets almost disappear in the noise.

${ }_{4}^{4}$ Theodorakis, E. A.; Drouet, K. E. Chem. Eur. J. 2000, 6, 1987-2001.
} 
diethylether. All organic phases were washed with brine, dried over $\mathrm{MgSO}_{4}$, and concentrated under reduced pressure. The residue was purified by flash chromatography. Excess silane was eluted with hexanes. The tagged alcohol 10b $(15.3 \mathrm{~g}, 88 \%)$ was eluted with the gradient $\mathrm{CH}_{2} \mathrm{Cl}_{2} /$ hexanes 4:96 to $\mathrm{CH}_{2} \mathrm{Cl}_{2} /$ hexanes 1:10. $[\alpha]_{\mathrm{D}}{ }^{20}+6.0$ (c 1.87, $\mathrm{CHCl}_{3}$ ); IR (neat) 2956, 2869, $1464,1351,1235,1133,1100,884,836,776,743 \mathrm{~cm}^{-1} ;{ }^{1} \mathrm{H}$ NMR $\left(300 \mathrm{MHz}, \mathrm{CDCl}_{3}\right) \delta$ 5.82-5.70 (m, 1H), $5.04(\mathrm{~s}, 1 \mathrm{H}), 4.99$ (d, $J=7.2 \mathrm{~Hz}, 1 \mathrm{H}), 3.94(\mathrm{~m}, 1 \mathrm{H}), 3.64(\mathrm{t}, J=6.4 \mathrm{~Hz}, 2 \mathrm{H}), 2.29-2.30$ (m, 1H), 2.02-2.23 (m, 2H), 1.65-1.57 (m, 2H), 1.08-0.83 (m, 28H), $0.03(\mathrm{~s}, 6 \mathrm{H}) ;{ }^{13} \mathrm{C}$ NMR $(75$ $\left.\mathrm{MHz}, \mathrm{CDCl}_{3}\right) \delta 140.2,114.8,73.2,59.8,43.1,36.6,25.8(3 \mathrm{C}), 25.6\left(\mathrm{t}, J_{\mathrm{FC}}=24 \mathrm{~Hz}\right), 18.2,17.7$ (4C), 14.8, 13.1, 13.0, 0.9, -5.4; ${ }^{19} \mathrm{~F}$ NMR (282 MHz, $\left.\mathrm{CDCl}_{3}\right) \delta-79.9(3 \mathrm{~F}),-115.6(2 \mathrm{~F}),-123.1$ (2F), -124.9; MS (EI) $m / z 561\left[\mathrm{M}-\mathrm{C}_{3} \mathrm{H}_{7}\right]^{+}$; HRMS (EI) calcd for $\mathrm{C}_{22} \mathrm{H}_{38} \mathrm{O}_{2} \mathrm{~F}_{9} \mathrm{Si}_{2}\left[\mathrm{M}-\mathrm{C}_{3} \mathrm{H}_{7}\right]^{+}$ 561.2267, found 561.2265.

\section{(2S,3S)-5-(tert-Butyldimethylsilyloxy)-3-[(3,3,4,4,5,5,5-heptafluoropentyl)-diisopropyl-} silyloxy]-2-methylpentanal 11a:

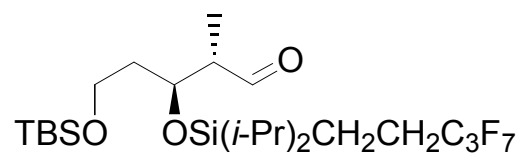

4-Methylmorpholine $N$-oxide $(4.21 \mathrm{~g}, 35.9 \mathrm{mmol})$ and $\mathrm{OsO}_{4}(280 \mathrm{mg}, 1.10 \mathrm{mmol})$ were dissolved in a solution of alkene 10a $(15.3 \mathrm{~g}, 27.6 \mathrm{mmol})$ in $96 \mathrm{ml} \mathrm{THF} / \mathrm{H}_{2} \mathrm{O} / \mathrm{t}-\mathrm{BuOH}$ 10:1:1. After stirring for $3.5 \mathrm{~h}$ at room temperature in the dark, the mixture was diluted with $\mathrm{H}_{2} \mathrm{O}(16 \mathrm{~mL})$ and $t-\mathrm{BuOH}$ $(16 \mathrm{~mL})$ and $\mathrm{NaIO}_{4}(8.86 \mathrm{~g}, 41.4 \mathrm{mmol})$ was added. After $2 \mathrm{~h}$, more $\mathrm{NaIO}_{4}(2.95 \mathrm{~g}, 13.8 \mathrm{mmol})$ was added and stirring continued for another $6 \mathrm{~h} . \mathrm{H}_{2} \mathrm{O}$ and ether were added and the phases were separated. The aqueous phase was extracted with ether. The combined organic phase was washed with $\mathrm{H}_{2} \mathrm{O}$ and brine, dried over $\mathrm{MgSO}_{4}$ and concentrated under reduced pressure. The residue was purified by flash chromatography (AcOEt/hexanes 5:95) to give aldehyde 11a (13.8 g, 90\%). $[\alpha]_{\mathrm{D}}^{20}+12.7\left(c 1.24, \mathrm{CHCl}_{3}\right)$; IR (neat) 2953, 2869, 1727, 1464, 1353, 1229, 1182, 1112, 949 , 
909, 885, $835 \mathrm{~cm}^{-1} ;{ }^{1} \mathrm{H}$ NMR (300 MHz, $\left.\mathrm{CDCl}_{3}\right) \delta 9.75(\mathrm{~s}, 1 \mathrm{H}), 4.34(\mathrm{~m}, 1 \mathrm{H}), 3.68(\mathrm{t}, J=6.0 \mathrm{~Hz}$, 2H), 2.60 (m, 1H), 2.09 (m, 2H), 1.86-1.65 (m, 2H), 1.15 (d, $J=7.0 \mathrm{~Hz}, 3 \mathrm{H}), 1.13-0.81$ (m, 25H), $0.03(\mathrm{~s}, 6 \mathrm{H}) ;{ }^{13} \mathrm{C} \mathrm{NMR}\left(75 \mathrm{MHz}, \mathrm{CDCl}_{3}\right) \delta 203.8,71.2,59.0,51.4,37.8,25.8(3 \mathrm{C}), 25.3\left(\mathrm{t}, J_{\mathrm{FC}}=\right.$ $24 \mathrm{~Hz}), 18.2,17.6$ (4C), 12.9 (2C), 10.1, 0.8, $-5.5(2 \mathrm{C}) ;{ }^{19} \mathrm{~F}$ NMR (282 MHz, $\left.\mathrm{CDCl}_{3}\right) \delta-79.5$ (3F), -116.3 (2F), -126.4 (2F); MS (EI) $m / z 541\left[\mathrm{M}-\mathrm{CH}_{3}\right]^{+}, 513\left[\mathrm{M}-\mathrm{C}_{3} \mathrm{H}_{7}\right]^{+}, 499[\mathrm{M}-$ $\left.\mathrm{C}_{4} \mathrm{H}_{9}\right]^{+}$; HRMS (EI) calcd for $\mathrm{C}_{20} \mathrm{H}_{36} \mathrm{O}_{3} \mathrm{~F}_{7} \mathrm{Si}_{2}\left[\mathrm{M}-\mathrm{C}_{3} \mathrm{H}_{7}\right]^{+}$513.2091, found 513.2119.

\section{$(2 R, 3 R)-5$-(tert-Butyldimethylsilyloxy)-3-[diisopropyl(3,3,4,4,5,5,6,6,6-nonafluorohexyl)-} silyloxy]-2-methylpentanal 11b:

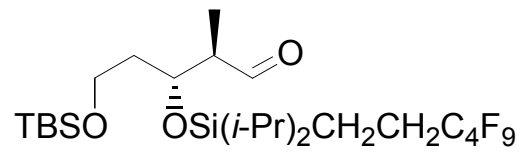

4-Methylmorpholine $\mathrm{N}$-oxide $(5.27 \mathrm{~g}, 45.0 \mathrm{mmol})$ and $\mathrm{OsO}_{4}(351 \mathrm{mg}, 1.38 \mathrm{mmol})$ were dissolved in a solution of alkene 10b $(20.9 \mathrm{~g}, 34.6 \mathrm{mmol})$ in $120 \mathrm{~mL}$ THF/ $\mathrm{H}_{2} \mathrm{O} / \mathrm{t}-\mathrm{BuOH}$ 10:1:1. After stirring for $3.5 \mathrm{~h}$ at room temperature in the dark, the mixture was diluted with $\mathrm{H}_{2} \mathrm{O}(20 \mathrm{~mL})$ and $t$ - $\mathrm{BuOH}(20 \mathrm{~mL})$ and $\mathrm{NaIO}_{4}(16.8 \mathrm{~g}, 78.5 \mathrm{mmol})$ was added portion wise within $4 \mathrm{~h}$. After stirring for another $2 \mathrm{~h}, \mathrm{H}_{2} \mathrm{O}$ and ether were added and the phases were separated. The aqueous phase was extracted with ether. The combined organic phase was washed with $\mathrm{H}_{2} \mathrm{O}$ and brine, dried over $\mathrm{MgSO}_{4}$ and concentrated under reduced pressure. The residue was purified by flash chromatography (AcOEt/hexanes 5:95) to give aldehyde 11b $(18.4 \mathrm{~g}, 88 \%) .[\alpha]_{\mathrm{D}}{ }^{20}-7.5(c 0.93$, $\mathrm{CHCl}_{3}$ ); IR (neat) 2955, 2869, 1727, 1464, 1220, 1133, 1008, 884, 839, 778, $743 \mathrm{~cm}^{-1}$; ${ }^{1} \mathrm{H}$ NMR $\left(300 \mathrm{MHz}, \mathrm{CDCl}_{3}\right) \delta 9.75(\mathrm{~s}, 1 \mathrm{H}), 4.34(\mathrm{~m}, 1 \mathrm{H}), 3.68(\mathrm{t}, J=6.0 \mathrm{~Hz}, 2 \mathrm{H}), 2.60(\mathrm{~m}, 1 \mathrm{H}), 2.10(\mathrm{~m}$, 2H), 1.86-1.65 (m, 2H), $1.15(\mathrm{~d}, J=7.0 \mathrm{~Hz}, 3 \mathrm{H}), 1.12-0.79(\mathrm{~m}, 25 \mathrm{H}), 0.03(\mathrm{~s}, 6 \mathrm{H}) ;{ }^{13} \mathrm{C}$ NMR $(75$ $\left.\mathrm{MHz}, \mathrm{CDCl}_{3}\right) \delta 203.8,71.2,59.0,51.4,37.8,25.8(3 \mathrm{C}), 25.5$ (t, $\left.J_{\mathrm{FC}}=24 \mathrm{~Hz}\right), 18.2,17.6(4 \mathrm{C})$, 12.9 (2C), 10.1, 0.9, -5.5 (2C); ${ }^{19} \mathrm{~F}$ NMR (282 MHz, $\left.\mathrm{CDCl}_{3}\right) \delta-79.9(3 \mathrm{~F}),-115.6(2 \mathrm{~F}),-123.1$ $(2 \mathrm{~F}),-124.9(2 \mathrm{~F})$. 


\section{Ethyl $\quad(2 E, 4 R, 5 S)-7-($ tert-butyldimethylsilyloxy)-5-[(3,3,4,4,5,5,5-heptafluoropentyl)-diiso-} propylsilyloxy]-4-methylhept-2-enoate 12a:

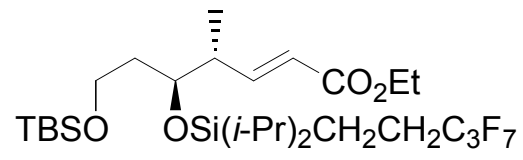

Triethylphosphonoacetate $(5.92 \mathrm{~g}, 26.4 \mathrm{mmol})$ was added within $10 \mathrm{~min}$ to $\mathrm{NaH}(1.04 \mathrm{~g}$ of $60 \%$ dispersion in mineral oil, $26.0 \mathrm{mmol}$ ) in $90 \mathrm{~mL}$ dry $\mathrm{THF}$ at $0{ }^{\circ} \mathrm{C}$. After stirring for $10 \mathrm{~min}$ at $0{ }^{\circ} \mathrm{C}$, the suspension was warmed to $30{ }^{\circ} \mathrm{C}$ for $20 \mathrm{~min}$. A solution of aldehyde 11a in $35 \mathrm{~mL}$ dry THF was added dropwise to the obtained clear solution at $-78{ }^{\circ} \mathrm{C}$. After $30 \mathrm{~min}$, the mixture was allowed to warm to $0{ }^{\circ} \mathrm{C}$ and stirring was continued for $2 \mathrm{~h}$ at this temperature. Phosphate buffer pH $7(100 \mathrm{~mL})$ was added and the mixture was diluted with ether $(200 \mathrm{~mL})$. The phases were separated. The aqueous phase was extracted with ether. The combined organic phase was washed with sat. aq. $\mathrm{NH}_{4} \mathrm{Cl}$ solution and brine, dried over $\mathrm{MgSO}_{4}$ and concentrated under reduced pressure. The residue was purified by flash chromatography (AcOEt/hexanes gradient 4:96 to 10:90) to give ester $12 \mathrm{a}(10.3 \mathrm{~g}, 79 \%)$. $[\alpha]_{\mathrm{D}}{ }^{20}+7.9\left(c 1.12, \mathrm{CHCl}_{3}\right)$; IR (neat) 2954, 2868, 1724, $1653,1464,1353,1229,1182,1111,950,909,886,835,777,748,708 \mathrm{~cm}^{-1} ;{ }^{1} \mathrm{H}$ NMR $(300$ $\left.\mathrm{MHz}, \mathrm{CDCl}_{3}\right) \delta 6.93(\mathrm{dd}, J=15.8,7.5 \mathrm{~Hz}, 1 \mathrm{H}), 5.81(\mathrm{dd}, J=15.8,1.0 \mathrm{~Hz}, 1 \mathrm{H}), 4.18(\mathrm{q}, J=7.1$ $\mathrm{Hz}, 2 \mathrm{H}), 4.05-3.99(\mathrm{~m}, 1 \mathrm{H}), 3.64(\mathrm{t}, J=6.2 \mathrm{~Hz}, 2 \mathrm{H}), 2.60-2.46(\mathrm{~m}, 1 \mathrm{H}), 2.19-2.01(\mathrm{~m}, 2 \mathrm{H})$, $1.72-1.51(\mathrm{~m}, 2 \mathrm{H}), 1.28(\mathrm{t}, J=7.1 \mathrm{~Hz}, 3 \mathrm{H}), 1.10(\mathrm{~d}, J=6.8 \mathrm{~Hz}, 3 \mathrm{H}), 1.05(\mathrm{~m}, 14 \mathrm{H}), 0.89-0.83$ $(\mathrm{m}, 11 \mathrm{H}), 0.02(\mathrm{~s}, 6 \mathrm{H}) ;{ }^{13} \mathrm{C} \mathrm{NMR}\left(75 \mathrm{MHz}, \mathrm{CDCl}_{3}\right) \delta 166.4,150.2,121.8,72.8,60.2,59.4,41.8$, 37.1, $25.8(3 \mathrm{C}), 25.4\left(\mathrm{t}, J_{\mathrm{FC}}=24 \mathrm{~Hz}\right), 18.2,17.7(4 \mathrm{C}), 14.7,14.2,13.0,12.9,0.9,-5.5(2 \mathrm{C}) ;{ }^{19} \mathrm{~F}$ NMR (282 MHz, $\left.\mathrm{CDCl}_{3}\right) \delta-79.5(3 \mathrm{~F}),-116.3(2 \mathrm{~F}),-126.4(2 \mathrm{~F}) ; \mathrm{MS}(\mathrm{ESI}) \mathrm{m} / z 649.3$ [M + $\mathrm{Na}]^{+}$; HRMS (ESI) calcd for $\mathrm{C}_{27} \mathrm{H}_{49} \mathrm{O}_{4} \mathrm{~F}_{7} \mathrm{Si}_{2} \mathrm{Na}[\mathrm{M}+\mathrm{Na}]^{+}$649.2955, found 649.2960.

Ethyl (2E,4S,5R)-7-(tert-butyldimethylsilyloxy)-5-[diisopropyl(3,3,4,4,5,5,6,6,6-nonafluorohexyl)silyloxy]-4-methylhept-2-enoate 12b: 


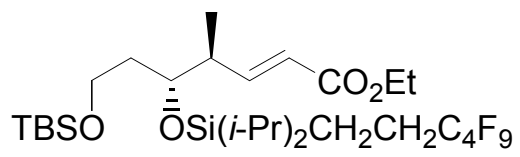

Triethylphosphonoacetate $(8.61 \mathrm{~g}, 38.4 \mathrm{mmol})$ was added within $10 \mathrm{~min}$ to $\mathrm{NaH}(1.51 \mathrm{~g}$ of $60 \%$ dispersion in mineral oil, $37.8 \mathrm{mmol}$ ) in $120 \mathrm{~mL}$ dry $\mathrm{THF}$ at $0{ }^{\circ} \mathrm{C}$. After stirring for $10 \mathrm{~min}$ at $0{ }^{\circ} \mathrm{C}$, the suspension was warmed to $30^{\circ} \mathrm{C}$ for $20 \mathrm{~min}$. A solution of aldehyde $\mathbf{1 1 b}$ in $50 \mathrm{~mL}$ dry THF was added dropwise to the obtained clear solution at $-78^{\circ} \mathrm{C}$. After $30 \mathrm{~min}$, the mixture was allowed to warm to $0{ }^{\circ} \mathrm{C}$ and stirring was continued for $2 \mathrm{~h}$ at this temperature. Phosphate buffer pH $7(200 \mathrm{~mL})$ was added and the mixture was diluted with ether $(200 \mathrm{~mL})$. The phases were separated. The aqueous phase was extracted with ether. The combined organic phase was washed with sat. aq. $\mathrm{NH}_{4} \mathrm{Cl}$ solution and brine, dried over $\mathrm{MgSO}_{4}$ and concentrated under reduced pressure. The residue was purified by flash chromatography (AcOEt/hexanes gradient 4:96 to 10:90) to give ester $\mathbf{1 2 b}(16.1 \mathrm{~g}, 79 \%)$. [ $\alpha]_{\mathrm{D}}{ }^{20}-6.6\left(c 1.00, \mathrm{CHCl}_{3}\right)$; IR (neat) 2955, 2869, 1724, 1464, 1236, 1133, 1100, 884, 838, 777, $743 \mathrm{~cm}^{-1} ;{ }^{1} \mathrm{H}$ NMR $\left(300 \mathrm{MHz}, \mathrm{CDCl}_{3}\right) \delta 6.93(\mathrm{dd}, J=$ $15.8,7.5 \mathrm{~Hz}, 1 \mathrm{H}), 5.81(\mathrm{dd}, J=15.8,1.0 \mathrm{~Hz}, 1 \mathrm{H}), 4.18(\mathrm{q}, J=7.1 \mathrm{~Hz}, 2 \mathrm{H}), 4.05-3.99(\mathrm{~m}, 1 \mathrm{H})$, $3.64(\mathrm{t}, J=6.2 \mathrm{~Hz}, 2 \mathrm{H}), 2.60-2.46(\mathrm{~m}, 1 \mathrm{H}), 2.21-2.00(\mathrm{~m}, 2 \mathrm{H}), 1.71-1.50(\mathrm{~m}, 2 \mathrm{H}), 1.28(\mathrm{t}, J=7.1$ $\mathrm{Hz}, 3 \mathrm{H}), 1.10(\mathrm{~d}, J=6.8 \mathrm{~Hz}, 3 \mathrm{H}), 1.05(\mathrm{~m}, 14 \mathrm{H}), 0.92-0.81(\mathrm{~m}, 11 \mathrm{H}), 0.03(\mathrm{~s}, 6 \mathrm{H}) ;{ }^{13} \mathrm{C} \mathrm{NMR}(75$ $\left.\mathrm{MHz}, \mathrm{CDCl}_{3}\right) \delta 166.4,150.1,125-105\left(\mathrm{~m}, \mathrm{C}_{4} \mathrm{~F}_{9}\right), 121.8,72.8,60.2,59.4,41.8,37.1,25.8(3 \mathrm{C})$, $25.5\left(\mathrm{t}, J_{\mathrm{FC}}=24 \mathrm{~Hz}\right), 18.2,17.7(4 \mathrm{C}), 14.7,14.2,13.0(2 \mathrm{C}), 0.9,-5.5(2 \mathrm{C}) ;{ }^{19} \mathrm{~F}$ NMR $(282 \mathrm{MHz}$, $\left.\mathrm{CDCl}_{3}\right) \delta-79.9(3 \mathrm{~F}),-115.6(2 \mathrm{~F}),-123.1(2 \mathrm{~F}),-124.9(2 \mathrm{~F})$; MS (ESI) $m / z 699.3[\mathrm{M}+\mathrm{Na}]^{+}$; HRMS (ESI) calcd for $\mathrm{C}_{28} \mathrm{H}_{49} \mathrm{O}_{4} \mathrm{~F}_{9} \mathrm{Si}_{2} \mathrm{Na}[\mathrm{M}+\mathrm{Na}]^{+}$699.2923, found 699.2911.

(4R)-4-Benzyl-3-\{(2R,3S)-5-tert-butyldimethylsilyloxy-3-[diisopropyl-(3,3,4,4,5,5,6,6,7,7, 8,8,8-tridecafluorooctylsilyl)]-2-methylpentanoyl\}-1,3-oxazolidin-2-one 14c: 


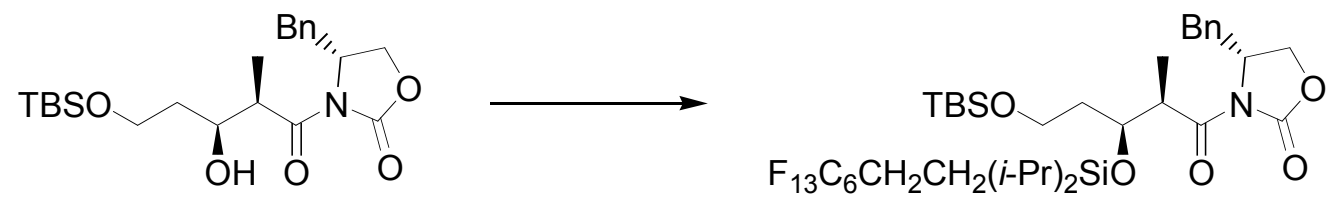

Trifluoromethansulfonic acid $(8.40 \mathrm{~mL}, 94.9 \mathrm{mmol})$ was added dropwise at $0{ }^{\circ} \mathrm{C}$ to neat $\mathrm{F}_{13} \mathrm{C}_{6} \mathrm{CH}_{2} \mathrm{CH}_{2}(i-\mathrm{Pr})_{2} \mathrm{SiH}^{5}(52.4 \mathrm{~g}, 113 \mathrm{mmol})$ that is continuously purged with argon. After the vigorous gas evolution had ceased, the mixture was allowed to warm to room temperature and left to stir overnight. The reaction mixture was then cooled to $-30{ }^{\circ} \mathrm{C}$ and diluted with $\mathrm{CH}_{2} \mathrm{Cl}_{2}$ $(135 \mathrm{~mL})$. After addition of 2,6-lutidine $(22.1 \mathrm{~mL}, 189 \mathrm{mmol})$, a solution of the aldol adduct ${ }^{6}$ in $\mathrm{CH}_{2} \mathrm{Cl}_{2}(130 \mathrm{~mL})$ was added and the reaction mixture was stirred at $0{ }^{\circ} \mathrm{C}$ for $3 \mathrm{~h}$. The reaction mixture was poured onto phosphate buffer $\mathrm{pH} 7$ at $0{ }^{\circ} \mathrm{C}$ and extracted with $\mathrm{CH}_{2} \mathrm{Cl}_{2}$. The combined organic extracts were washed with brine, dried over $\mathrm{MgSO}_{4}$, and concentrated under reduced pressure. The residue was subjected to flash chromatography $\left(\mathrm{CH}_{2} \mathrm{Cl}_{2} /\right.$ hexanes 1:2 to 1:1) to give crude tagged oxazolidinone $14 \mathrm{c}(55.4 \mathrm{~g})$, which was used without complete purification. An analytical sample was obtained by repeated flash chromatography $\left(\mathrm{CH}_{2} \mathrm{Cl}_{2} /\right.$ hexanes $1: 2$ to $\left.1: 1\right)$. $[\alpha]_{\mathrm{D}}{ }^{20}-22.7$ (c 1.15, $\left.\mathrm{CHCl}_{3}\right)$; IR (neat) 2952, 2867, 1785, 1705, 1464, $1239 \mathrm{~cm}^{-1} ;{ }^{1} \mathrm{H}$ NMR (300 MHz, $\left.\mathrm{CDCl}_{3}\right) \delta$ 7.36-7.20 (m, 5H), 4.65-4.56 (m, 1H), 4.33-4.25 $(\mathrm{m}, 1 \mathrm{H}), 4.21-4.08(\mathrm{~m}, 2 \mathrm{H}), 3.97-3.85(\mathrm{~m}, 1 \mathrm{H}), 3.77-3.61(\mathrm{~m}, 2 \mathrm{H}), 3.31(\mathrm{dd}, J=13.2,2.2 \mathrm{~Hz}$, 1H), $2.77(\mathrm{dd}, J=13.2,9.9 \mathrm{~Hz}, 1 \mathrm{H}), 2.26-2.04(\mathrm{~m}, 2 \mathrm{H}), 1.95-1.75(\mathrm{~m}, 2 \mathrm{H}), 1.24(\mathrm{~d}, J=6.6 \mathrm{~Hz}$, 3H), 1.14-1.01 (m, 14H), 0.93-0.80 (m, 11H), $0.05(\mathrm{~s}, 6 \mathrm{H}) ;{ }^{13} \mathrm{C}$ NMR $\left(75 \mathrm{MHz}, \mathrm{CDCl}_{3}\right) \delta 175.6$, 153.7, 136.0, 130.1 (2C), $129.6(2 \mathrm{C}), 128.0,124.1-105.4\left(\mathrm{~m}, \mathrm{C}_{6} \mathrm{~F}_{13}\right), 71.6,66.6,59.8,56.3,43.5$, 39.2, 38.3, 26.6 (2C), 26.5 (1C), 26.1 (m, $\left.\mathrm{CH}_{2} \mathrm{C}_{6} \mathrm{~F}_{13}\right), 18.9,18.3$ (4C), 13.6, 11.8 (2C), 1.4, -4.8 (2C); ${ }^{19} \mathrm{~F}$ NMR (282 MHz, $\left.\mathrm{CDCl}_{3}\right) \delta-79.6(3 \mathrm{~F}),-115.4(2 \mathrm{~F}),-120.8(2 \mathrm{~F}),-121.7(2 \mathrm{~F}),-122.0$

\footnotetext{
5 (a) Zhang, Q.; Rivkin, A.; Curran, D. P. J. Am. Chem. Soc. 2002, 124, 5774-5781. (b) The silanes are also commercially available from Fluorous Technologies Inc.

${ }^{6}$ (a) Phukan, P.; Bauer, M.; Maier, M. E. Synthesis 2003, 1324-1328. (b) Phukan, P.; Sasmal, S.; Maier, M. E. Eur. J. Org. Chem. 2003, 1733-1740.
} 
(2F), $-125.0(2 \mathrm{~F})$; MS (ESI) $m / z 904.3[\mathrm{M}+\mathrm{Na}]^{+}$; HRMS (ESI) calcd for $\mathrm{C}_{36} \mathrm{H}_{52} \mathrm{NO}_{5} \mathrm{~F}_{13} \mathrm{Si}_{2} \mathrm{Na}$ $[\mathrm{M}+\mathrm{Na}]^{+}$904.3074, found 904.3058.

(4S)-4-Benzyl-3-\{(2S,3R)-5-tert-butyldimethylsilyloxy-3-[(3,3,4,4,5,5,6,6,7,7,8,8,9,9,10,10, 10-heptadecafluorodecyl)diisopropylsilyloxy]-2-methylpentanoyl\}-1,3-oxazolidin-2-one 14d:

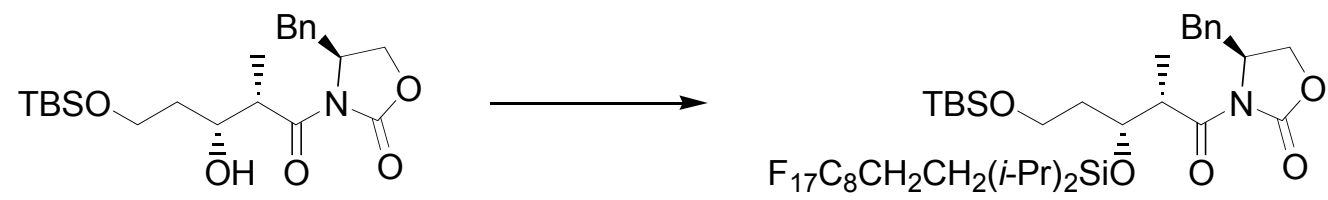

Trifluoromethansulfonic acid $(11.1 \mathrm{~mL}, 125 \mathrm{mmol})$ was added dropwise at $-35{ }^{\circ} \mathrm{C}$ to neat $\mathrm{F}_{17} \mathrm{C}_{8} \mathrm{CH}_{2} \mathrm{CH}_{2}(i-\mathrm{Pr})_{2} \mathrm{SiH}^{7}(87.7 \mathrm{~g}, 156 \mathrm{mmol})$ that is continuously purged with argon. After the vigorous gas evolution had ceased, the mixture was allowed to warm to room temperature and left to stir overnight. $\mathrm{CH}_{2} \mathrm{Cl}_{2}(200 \mathrm{~mL})$ was then added. The solution was cooled to $-30{ }^{\circ} \mathrm{C}$ and 2,6-lutidine $(28.7 \mathrm{~g}, 268 \mathrm{mmol})$ was added. A solution of the aldol adduct ${ }^{8}$ in $\mathrm{CH}_{2} \mathrm{Cl}_{2}(130 \mathrm{~mL})$ was added at $-30{ }^{\circ} \mathrm{C}$ within $30 \mathrm{~min}$ and stirring continued at $0{ }^{\circ} \mathrm{C}$ for $45 \mathrm{~min}$. The reaction was quenched with phosphate buffer $\mathrm{pH} 7(400 \mathrm{~mL})$ and the phases were separated. The aqueous phase was extracted with $\mathrm{CH}_{2} \mathrm{Cl}_{2}$ and ether. The combined organic phase was washed with brine, dried over $\mathrm{MgSO}_{4}$ and concentrated under reduced pressure. The residue was purified by flash chromatography. Excess silane was eluted with hexanes. The tagged oxazolidinone 14d (68.2 g, $78 \%$ ) was eluted with a gradient $\mathrm{CH}_{2} \mathrm{Cl}_{2} /$ hexanes $1: 2$ to $\mathrm{CH}_{2} \mathrm{Cl}_{2} /$ hexanes $3: 2$. $[\alpha]_{\mathrm{D}}{ }^{20}+22.0$ (c $1.11, \mathrm{CHCl}_{3}$ ); IR (neat) 2952, 2868, 1785, 1706, 1386, 1350, 1208, 1152, 1106, 887, $835 \mathrm{~cm}^{-1}$;

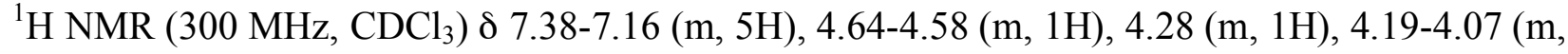
2H), $3.90(\mathrm{~m}, 1 \mathrm{H}), 3.68(\mathrm{~m}, 2 \mathrm{H}), 3.29(\mathrm{dd}, J=9.2,3.0 \mathrm{~Hz}, 1 \mathrm{H}), 2.75(\mathrm{dd}, J=13.4,9.7 \mathrm{~Hz}, 1 \mathrm{H})$,

\footnotetext{
7 (a) Zhang, Q.; Rivkin, A.; Curran, D. P. J. Am. Chem. Soc. 2002, 124, 5774-5781. (b) The silanes are also commercially available from Fluorous Technologies Inc.

${ }^{8}$ The enantiomer is known: (a) Phukan, P.; Bauer, M.; Maier, M. E. Synthesis 2003, 1324-1328. (b) Phukan, P.; Sasmal, S.; Maier, M. E. Eur. J. Org. Chem. 2003, 1733-1740.
} 
2.22-2.04 (m, 2H), 1.94-1.75 (m, 2H), $1.25(\mathrm{~m}, 2 \mathrm{H}), 1.23(\mathrm{~d}, J=6.9 \mathrm{~Hz}, 3 \mathrm{H}), 1.11-0.80(\mathrm{~m}, 23 \mathrm{H})$, 0.04 (s, 6H); ${ }^{13} \mathrm{C}$ NMR (75 MHz, $\left.\mathrm{CDCl}_{3}\right) \delta 174.9,153.0,135.3,129.4$ (2C), 128.9 (2C), 127.3, 125-105 (m), 71.0, 65.9, 59.1, 55.7, 42.8, 38.5, 37.6, 25.8 (3C), $25.3(\mathrm{~m}), 18.2,17.6(4 \mathrm{C}), 13.0$, 12.9, 11.0, 0.7, -5.5 (2C); ${ }^{19} \mathrm{~F}$ NMR (282 MHz, $\left.\mathrm{CDCl}_{3}\right) \delta-79.5$ (3F), -115.3 (2F), -120.7 (6F), -121.5 (2F), -122.0 (2F), -124.9 (2F); MS (ESI) $m / z 1004.3[\mathrm{M}+\mathrm{Na}]^{+}$; HRMS (ESI) calcd for $\mathrm{C}_{38} \mathrm{H}_{52} \mathrm{~F}_{17} \mathrm{O}_{5} \mathrm{Si}_{2} \mathrm{Na}[\mathrm{M}+\mathrm{Na}]^{+}$1004.3010, found 1004.2964.

\section{$(2 S, 3 S)-5$-(tert-Butyldimethylsilyloxy)-3-[diisopropyl-(3,3,4,4,5,5,6,6,7,7,8,8,8-trideca-}

\section{fluorooctyl)silyloxy]-2-methylpentan-1-ol 15c:}

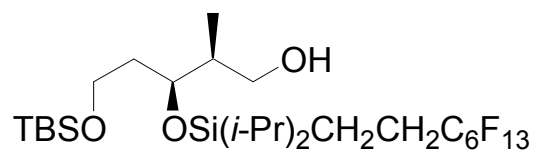

$\mathrm{LiBH}_{4}(87 \mathrm{~mL}, 2.0 \mathrm{M}$ solution in THF, $174 \mathrm{mmol})$ was added dropwise over $20 \mathrm{~min}$ to a solution of crude tagged oxazolidinone 14c $(51.0 \mathrm{~g})$ in THF $(193 \mathrm{~mL})$ and $\mathrm{MeOH}(7.1 \mathrm{~mL})$, maintaining the temperature at $5{ }^{\circ} \mathrm{C}$. After $2 \mathrm{~h}$, the mixture was warmed to room temperature and stirred for 3 h. The mixture was treated carefully with $1.0 \mathrm{M}$ aqueous solution of $\mathrm{NaOH}(175 \mathrm{~mL})$ at $0{ }^{\circ} \mathrm{C}$ and stirred at room temperature for $1 \mathrm{~h}$. The phases were separated and the aqueous phase was extracted with ether. The combined organic extracts were washed with brine, dried over $\mathrm{MgSO}_{4}$, and concentrated under reduced pressure. The residue was purified by flash chromatography $\left(\mathrm{CH}_{2} \mathrm{Cl}_{2} /\right.$ hexanes $\left.2: 1\right)$ to give alcohol $15 \mathrm{c}(23.6 \mathrm{~g}, 58 \%$ over 2 steps $)$. $[\alpha]_{\mathrm{D}}{ }^{20}-5.3$ (c 1.50 , $\mathrm{CHCl}_{3}$ ); IR (neat) 3413, 2955, 2869, 1464, 1240, $1145 \mathrm{~cm}^{-1} ;{ }^{1} \mathrm{H}$ NMR (300 MHz, CDCl 3$) \delta 4.11$ $(\mathrm{dt}, J=6.5,2.9 \mathrm{~Hz}, 1 \mathrm{H}), 3.73-3.60(\mathrm{~m}, 3 \mathrm{H}), 3.55(\mathrm{dd}, J=10.6,5.5 \mathrm{~Hz}, 1 \mathrm{H}), 2.24-1.85(\mathrm{~m}, 4 \mathrm{H})$, 1.79-1.66 (m, 2H), 1.07-1.06 (m, 12H), 0.91-0.83 (m, 14H), $0.04(\mathrm{~s}, 6 \mathrm{H}) ;{ }^{13} \mathrm{C} \mathrm{NMR}(75 \mathrm{MHz}$, $\left.\mathrm{CDCl}_{3}\right) \delta 120-105\left(\mathrm{~m}, \mathrm{C}_{6} \mathrm{~F}_{13}\right), 72.7,65.9,59.9,40.2,36.5,26.0(3 \mathrm{C}), 25.8\left(\mathrm{t}, J_{\mathrm{FC}}=24 \mathrm{~Hz}\right), 18.4$, 17.9 (4C), 13.2, 11.8 (2C), 1.2, -5.3 (2C); ${ }^{19} \mathrm{~F}$ NMR (282 MHz, $\left.\mathrm{CDCl}_{3}\right) \delta-79.6(3 \mathrm{~F}),-115.3$ 
(2F), $-120.8(2 \mathrm{~F}),-121.7(2 \mathrm{~F}),-122.0(2 \mathrm{~F}),-125.0$ (2F); MS (ESI) $m / z 731.3[\mathrm{M}+\mathrm{Na}]^{+}$; HRMS (ESI) calcd for $\mathrm{C}_{26} \mathrm{H}_{45} \mathrm{O}_{3} \mathrm{~F}_{13} \mathrm{Si}_{2} \mathrm{Na}[\mathrm{M}+\mathrm{Na}]^{+}$731.2597, found 731.2620.

\section{$(2 R, 3 R)$-5-(tert-Butyldimethylsilyloxy)-3-[(3,3,4,4,5,5,6,6,7,7,8,8,9,9,10,10,10-heptadeca-}

\section{fluorodecyl)diisopropylsilyloxy]-2-methylpentan-1-ol 15d:}

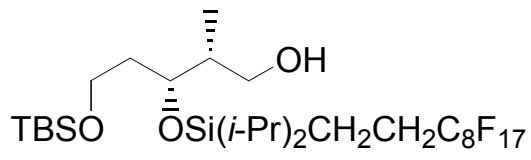

$\mathrm{LiBH}_{4}(104 \mathrm{~mL}, 2.0 \mathrm{M}$ solution in THF, $208 \mathrm{mmol}$ ) was added dropwise to a solution of tagged aldol adduct 14d $(68.0 \mathrm{~g}, 69.2 \mathrm{mmol})$ in THF $(230 \mathrm{~mL})$ and $\mathrm{MeOH}(8.5 \mathrm{~mL})$ at $0^{\circ} \mathrm{C}$. After $3 \mathrm{~h}$ stirring at $0^{\circ} \mathrm{C}$, the mixture was warmed to room temperature and stirring continued for $1 \mathrm{~h}$. The mixture was treated carefully with $1.0 \mathrm{M}$ aqueous solution of $\mathrm{NaOH}(200 \mathrm{~mL})$ at $0^{\circ} \mathrm{C}$ and stirred at room temperature for $1 \mathrm{~h}$. The phases were separated and the aqueous phase was extracted with ether. The combined organic extracts were washed with brine, dried over $\mathrm{MgSO}_{4}$, and concentrated under reduced pressure. The residue was purified by flash chromatography $\left(\mathrm{CH}_{2} \mathrm{Cl}_{2} /\right.$ hexanes $2: 1$ to $\left.\mathrm{CH}_{2} \mathrm{Cl}_{2} 100 \%\right)$ to give alcohol 15d (42.2 g, 75\%). $[\alpha]_{\mathrm{D}}^{20}+4.7(c 0.92$, $\mathrm{CHCl}_{3}$ ); IR (neat) $3395,2955,2869,1465,1206,1152,1097,887,835,777,706,658 \mathrm{~cm}^{-1} ;{ }^{1} \mathrm{H}$ NMR (300 MHz, $\left.\mathrm{CDCl}_{3}\right) \delta 4.11(\mathrm{~m}, 1 \mathrm{H}), 3.72-3.64(\mathrm{~m}, 3 \mathrm{H}), 3.58-3.53(\mathrm{~m}, 1 \mathrm{H}), 2.25-2.03(\mathrm{~m}$, 2H), 2.01-1.90 (m, 1H), $1.72(\mathrm{~m}, 2 \mathrm{H}), 1.53$ (br s, 1H, OH), 1.11-1.01 (m, 14H), 0.94-0.82 (m, 14H), $0.04(\mathrm{~s}, 6 \mathrm{H}) ;{ }^{13} \mathrm{C}$ NMR (75 MHz, $\left.\mathrm{CDCl}_{3}\right) \delta 120-105\left(\mathrm{~m}, \mathrm{C}_{8} \mathrm{~F}_{17}\right), 72.5$, 65.7, 59.6, 40.0,

36.3, 25.8 (3C), $25.6\left(\mathrm{~m}, \mathrm{CH}_{2} \mathrm{C}_{8} \mathrm{~F}_{17}\right), 18.2,17.6$ (4C), $13.0(2 \mathrm{C}), 11.6,1.0,-5.5(2 \mathrm{C}) ;{ }^{19} \mathrm{~F}$ NMR $\left(282 \mathrm{MHz}, \mathrm{CDCl}_{3}\right) \delta-79.5(3 \mathrm{~F}),-115.3(2 \mathrm{~F}),-120.7(2 \mathrm{~F}),-121.5(2 \mathrm{~F}),-122.0(2 \mathrm{~F}),-124.9$ (2F); MS (ESI) $m / z 831.2[\mathrm{M}+\mathrm{Na}]^{+}$; HRMS (ESI) calcd for $\mathrm{C}_{28} \mathrm{H}_{45} \mathrm{O}_{3} \mathrm{~F}_{17} \mathrm{Si}_{2} \mathrm{Na}[\mathrm{M}+\mathrm{Na}]^{+}$ 831.2534 , found 831.2468 . 


\section{(2R,3S)-5-(tert-Butyldimethylsilyloxy)-3-[diisopropyl-(3,3,4,4,5,5,6,6,7,7,8,8,8-trideca-}

fluorooctyl)silyloxy]-2-methylpentanal:

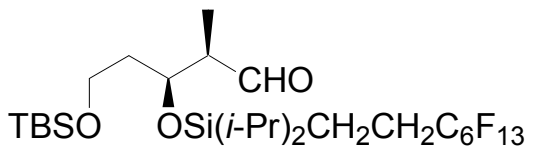

A solution of alcohol $14 \mathrm{c}(23.5 \mathrm{~g}, 33.2 \mathrm{mmol})$ in $\mathrm{CH}_{2} \mathrm{Cl}_{2}(235 \mathrm{~mL})$ was cooled to $0{ }^{\circ} \mathrm{C}$. TEMPO (52.0 mg, $333 \mu \mathrm{mol})$ was added followed by $2.75 \mathrm{M}$ aqueous solution of potassium bromide $(7.30 \mathrm{~mL})$ and $1.6 \mathrm{M}$ aqueous solution of potassium hydrogen carbonate $(35.4 \mathrm{~mL})$. To the rapidly stirred two-phase mixture was added a solution of $\mathrm{NaOCl}(55.2 \mathrm{~mL}$ of $6.15 \%$ solution, $45.6 \mathrm{mmol}$ ) over $20 \mathrm{~min}$. The resulting mixture was stirred for additional $45 \mathrm{~min}$ at $0{ }^{\circ} \mathrm{C}$. A 1.0 $\mathrm{M}$ aqueous solution of sodium $\mathrm{Na}_{2} \mathrm{~S}_{2} \mathrm{O}_{3}(25 \mathrm{~mL})$ was added. The phases were separated and the aqueous phase was extracted with $\mathrm{CH}_{2} \mathrm{Cl}_{2}$. The combined organic extracts were washed with brine, dried over $\mathrm{MgSO}_{4}$, and concentrated under reduced pressure. The residue was purified by flash chromatography $\left(\mathrm{CH}_{2} \mathrm{Cl}_{2} /\right.$ hexanes $\left.1: 2\right)$ to give the aldehyde $(19.4 \mathrm{~g}, 83 \%)$. $[\alpha]_{\mathrm{D}}{ }^{20}-9.0(c$ 1.53, $\mathrm{CHCl}_{3}$ ); IR (neat) 2954, 2870, 1711, 1463, $1242 \mathrm{~cm}^{-1} ;{ }^{1} \mathrm{H}$ NMR (300 MHz, $\left.\mathrm{CDCl}_{3}\right) \delta 9.79$ $(\mathrm{s}, 1 \mathrm{H}), 4.52(\mathrm{dt}, J=6.6,2.9 \mathrm{~Hz}, 1 \mathrm{H}), 3.71-3.59(\mathrm{~m}, 2 \mathrm{H}), 2.54(\mathrm{dq}, J=7.0,2.9 \mathrm{~Hz}, 1 \mathrm{H})$, 2.18-1.96 (m, 2H), $1.76(\mathrm{q}, J=6.2 \mathrm{~Hz}, 2 \mathrm{H}), 1.09$ (d, $J=7.0 \mathrm{~Hz}, 3 \mathrm{H}), 1.04-1.03(\mathrm{~m}, 14 \mathrm{H})$, 0.88-0.81 (m, 11H), $0.04(\mathrm{~s}, 6 \mathrm{H}) ;{ }^{13} \mathrm{C} \mathrm{NMR}\left(75 \mathrm{MHz}, \mathrm{CDCl}_{3}\right) \delta 204.4,121.7-107.8\left(\mathrm{~m}, \mathrm{C}_{6} \mathrm{~F}_{13}\right)$, 69.8, 59.3, 51.0, 37.4, $25.8(3 \mathrm{C}), 25.5\left(\mathrm{t}, J_{\mathrm{FC}}=23.4 \mathrm{~Hz}\right), 18.2,17.6(4 \mathrm{C}), 12.9(2 \mathrm{C}), 7.3,0.9,-5.5$ (2C); ${ }^{19} \mathrm{~F}$ NMR (282 MHz, $\left.\mathrm{CDCl}_{3}\right) \delta$-79.6 (3F), -115.4 (2F), -120.8 (2F), -121.7 (2F), -122.1 (2F), -125.0 (2F); MS (EI) $m / z 706[\mathrm{M}]^{+}$; HRMS (EI) calcd for $\mathrm{C}_{26} \mathrm{H}_{43} \mathrm{O}_{3} \mathrm{~F}_{13} \mathrm{Si}_{2}[\mathrm{M}]^{+} 706.2543$, found 706.2584 .

(2S,3R)-5-(tert-Butyldimethylsilyloxy)-3-[(3,3,4,4,5,5,6,6,7,7,8,8,9,9,10,10,10-heptadecafluorodecyl)diisopropylsilyloxy]-2-methylpentanal: 


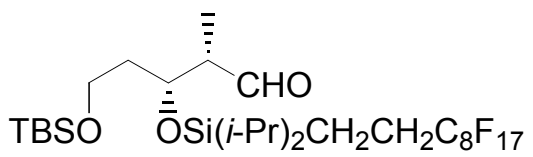

A solution of alcohol 14d $(41.9 \mathrm{~g}, 51.8 \mathrm{mmol})$ in $\mathrm{CH}_{2} \mathrm{Cl}_{2}(350 \mathrm{~mL})$ was cooled to $0{ }^{\circ} \mathrm{C}$. TEMPO (80.9 mg, $518 \mu \mathrm{mol}$ ) was added followed by $2.75 \mathrm{M}$ aqueous solution of potassium bromide (11.3 $\mathrm{mL})$ and 1.6 $\mathrm{M}$ aqueous solution of potassium hydrogen carbonate $(55.0 \mathrm{~mL})$. To the rapidly stirred two-phase mixture was added a solution of $\mathrm{NaOCl}(86.5 \mathrm{~g}$ of $6.15 \%$ solution, 88.1 mmol) over $35 \mathrm{~min}$. The resulting mixture was stirred for additional $50 \mathrm{~min}$ at $0{ }^{\circ} \mathrm{C}$. A $1.0 \mathrm{M}$ aqueous solution of sodium $\mathrm{Na}_{2} \mathrm{~S}_{2} \mathrm{O}_{3}(40 \mathrm{~mL})$ was added. The phases were separated and the aqueous phase was extracted with $\mathrm{CH}_{2} \mathrm{Cl}_{2}$. The combined organic extracts were washed with brine, dried over $\mathrm{MgSO}_{4}$, and concentrated under reduced pressure. The residue was purified by flash chromatography $\left(\mathrm{CH}_{2} \mathrm{Cl}_{2} /\right.$ hexanes $\left.1: 2\right)$ to give the aldehyde $(34.7 \mathrm{~g}, 83 \%)$. $[\alpha]_{\mathrm{D}}{ }^{20}+15.8(c$ $\left.1.06, \mathrm{CHCl}_{3}\right)$; IR (neat) 2953, 2867, 1729, 1243, 1207, 1152, 1103, $834 \mathrm{~cm}^{-1} ;{ }^{1} \mathrm{H}$ NMR (300 $\left.\mathrm{MHz}, \mathrm{CDCl}_{3}\right) \delta 9.79(\mathrm{~s}, 1 \mathrm{H}), 4.52(\mathrm{dt}, J=6.6,2.9 \mathrm{~Hz}, 1 \mathrm{H}), 3.71-3.58(\mathrm{~m}, 2 \mathrm{H}), 2.54(\mathrm{dq}, J=7.0$, $2.9 \mathrm{~Hz}, 1 \mathrm{H}), 2.18-1.96(\mathrm{~m}, 2 \mathrm{H}), 1.76(\mathrm{q}, J=6.2 \mathrm{~Hz}, 2 \mathrm{H}), 1.09(\mathrm{~d}, J=7.0 \mathrm{~Hz}, 3 \mathrm{H}), 1.05-1.01(\mathrm{~m}$, $12 \mathrm{H}), 0.89-0.81(\mathrm{~m}, 11 \mathrm{H}), 0.04(\mathrm{~s}, 6 \mathrm{H}) ;{ }^{13} \mathrm{C} \mathrm{NMR}\left(75 \mathrm{MHz}, \mathrm{CDCl}_{3}\right) \delta 204.5,120-105\left(\mathrm{~m}, \mathrm{C}_{8} \mathrm{~F}_{17}\right)$, 69.8, 59.3, 50.9, 37.3, $25.8(3 \mathrm{C}), 25.4\left(\mathrm{t}, J_{\mathrm{FC}}=23.4 \mathrm{~Hz}\right), 18.1,17.6(4 \mathrm{C}), 12.9(2 \mathrm{C}), 7.2,0.8,-5.6$ $(2 \mathrm{C}) ;{ }^{19} \mathrm{~F}$ NMR $\left(282 \mathrm{MHz}, \mathrm{CDCl}_{3}\right) \delta-79.5(3 \mathrm{~F}),-115.3(2 \mathrm{~F}),-120.7(6 \mathrm{~F}),-121.5(2 \mathrm{~F}),-122.1$ $(2 \mathrm{~F}),-124.9(2 \mathrm{~F})$.

\section{Ethyl $(2 E, 4 S, 5 S)-7-($ tert-butyldimethylsilyloxy)-5-[diisopropyl-(3,3,4,4,5,5,6,6,7,7,8,8,8-}

tridecafluorooctyl)silyloxy]-4-methylhept-2-enoate 12c:

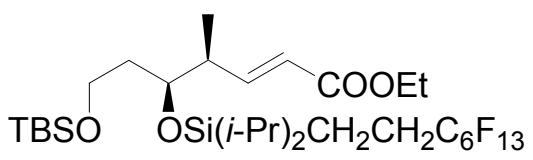


Triethyl phosphonoacetate $(6.90 \mathrm{~mL}, 34.8 \mathrm{mmol})$ was added dropwise over $10 \mathrm{~min}$ to a stirred suspension of $\mathrm{NaH}(1.36 \mathrm{~g}, 34.0 \mathrm{mmol}, 60 \%$ dispersion in mineral oil) in THF $(110 \mathrm{~mL})$, maintaining the temperature at $0{ }^{\circ} \mathrm{C}$. The mixture was warmed to $30^{\circ} \mathrm{C}$ with a water bath and stirred for $20 \mathrm{~min}$. Then, the mixture was cooled back to $-78{ }^{\circ} \mathrm{C}$ and a solution of the above aldehyde $(19.3 \mathrm{~g}, 27.2 \mathrm{mmol})$ in THF $(45 \mathrm{~mL})$ was added. After stirring at $-78{ }^{\circ} \mathrm{C}$ for $30 \mathrm{~min}$, the resulting mixture was warmed to $0^{\circ} \mathrm{C}$ and stirring continued for $3 \mathrm{~h}$. The mixture was quenched with phosphate buffer $\mathrm{pH} 7.0$ and extracted with ether. The combined organic extracts were washed with saturated aqueous $\mathrm{NH}_{4} \mathrm{Cl}$ solution and brine, dried over $\mathrm{MgSO}_{4}$, and concentrated under reduced pressure. The residue was purified by flash chromatography $\left(\mathrm{CH}_{2} \mathrm{Cl}_{2} /\right.$ hexanes 1:3 to 1:1) to give the unsaturated ester 12c $(18.5 \mathrm{~g}, 87 \%)$. $[\alpha]_{\mathrm{D}}{ }^{20}-21.1$ (c 2.01, $\mathrm{CHCl}_{3}$ ); IR (neat) 2945, 2866, 1724, 1655, 1468, $1244 \mathrm{~cm}^{-1} ;{ }^{1} \mathrm{H}$ NMR $\left(300 \mathrm{MHz}, \mathrm{CDCl}_{3}\right) \delta 7.07$ (dd, $J=15.9,6.8 \mathrm{~Hz}, 1 \mathrm{H}), 5.82(\mathrm{dd}, J=15.9,1.4 \mathrm{~Hz}, 1 \mathrm{H}), 4.18(\mathrm{q}, J=7.1 \mathrm{~Hz}, 2 \mathrm{H}), 4.05-3.99(\mathrm{~m}$, 1H), $3.65(\mathrm{t}, J=6.2 \mathrm{~Hz}, 2 \mathrm{H}), 2.56-2.50(\mathrm{~m}, 1 \mathrm{H}), 2.20-2.02(\mathrm{~m}, 2 \mathrm{H}), 1.74-1.55(\mathrm{~m}, 2 \mathrm{H}), 1.28(\mathrm{t}, J$ $=7.1 \mathrm{~Hz}, 3 \mathrm{H}), 1.05-1.02(\mathrm{~m}, 17 \mathrm{H}), 0.89-0.81(\mathrm{~m}, 11 \mathrm{H}), 0.03(\mathrm{~s}, 6 \mathrm{H}) ;{ }^{13} \mathrm{C}$ NMR $(75 \mathrm{MHz}$, $\left.\mathrm{CDCl}_{3}\right) \delta 166.5,151.2,121.3,121.1-105.7\left(\mathrm{~m}, \mathrm{C}_{6} \mathrm{~F}_{13}\right), 73.0,60.1,59.4,41.5,37.0,25.8(3 \mathrm{C})$, $25.6\left(\mathrm{t}, J_{\mathrm{FC}}=23.5 \mathrm{~Hz}\right), 18.2,17.7(4 \mathrm{C}), 14.1,13.2,13.0,13.0,0.9,-5.5(2 \mathrm{C}) ;{ }^{19} \mathrm{~F}$ NMR $(282$ $\left.\mathrm{MHz}, \mathrm{CDCl}_{3}\right) \delta-79.6(3 \mathrm{~F}),-115.4(2 \mathrm{~F}),-120.8(2 \mathrm{~F}),-121.7(2 \mathrm{~F}),-122.1(2 \mathrm{~F}),-125.0(2 \mathrm{~F}) ; \mathrm{MS}$ (ESI) $m / z 799.3[\mathrm{M}+\mathrm{Na}]^{+}$; HRMS (ESI) calcd for $\mathrm{C}_{30} \mathrm{H}_{49} \mathrm{O}_{4} \mathrm{~F}_{13} \mathrm{Si}_{2} \mathrm{Na}[\mathrm{M}+\mathrm{Na}]^{+}$799.2860, found 799.2878 .

\section{Ethyl (2E,4R,5R)-7-(tert-butyldimethylsilyloxy)-5-[(3,3,4,4,5,5,6,6,7,7,8,8,9,9,10,10,10-} heptadecafluorodecyl)diisopropylsilyloxy]-4-methylhept-2-enoate 12d:

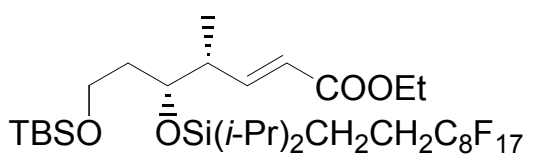


Triethyl phosphonoacetate $(10.8 \mathrm{~mL}, 54.5 \mathrm{mmol})$ was added dropwise over $10 \mathrm{~min}$ to a stirred suspension of $\mathrm{NaH}(2.13 \mathrm{~g}, 53.3 \mathrm{mmol}, 60 \%$ dispersion in mineral oil) in THF (170 mL), maintaining the temperature at $0{ }^{\circ} \mathrm{C}$. The mixture was warmed to $30{ }^{\circ} \mathrm{C}$ with a water bath and stirred for $20 \mathrm{~min}$. Then, the mixture was cooled back to $-78{ }^{\circ} \mathrm{C}$ and a solution of the above aldehyde $(34.4 \mathrm{~g}, 42.6 \mathrm{mmol})$ in THF $(70 \mathrm{~mL})$ was added. After stirring at $-78{ }^{\circ} \mathrm{C}$ for $30 \mathrm{~min}$, the resulting mixture was warmed to $0{ }^{\circ} \mathrm{C}$ and stirring continued for $2 \mathrm{~h}$. The mixture was quenched with phosphate buffer $\mathrm{pH} 7.0$ and extracted with ether. The combined organic extracts were washed with saturated aqueous $\mathrm{NH}_{4} \mathrm{Cl}$ solution and brine, dried over $\mathrm{MgSO}_{4}$, and concentrated under reduced pressure. The residue was purified by flash chromatography (EtOAc/hexanes 2:98 to 10:90; early mixture fractions purified by second chromatography using $\mathrm{CH}_{2} \mathrm{Cl}_{2} /$ hexanes $\left.1: 3\right)$ to give the unsaturated ester 12d $(29.7 \mathrm{~g}, 80 \%) \cdot[\alpha]_{\mathrm{D}}^{20}+17.3$ (c 1.49, $\mathrm{CHCl}_{3}$ ); IR (neat) 2955, 2869, 1724, 1654, 1465, 1368, 1206, 1098, 834, $777 \mathrm{~cm}^{-1} ;{ }^{1} \mathrm{H}$ NMR $\left(300 \mathrm{MHz}, \mathrm{CDCl}_{3}\right) \delta 7.07$ (dd, $\left.J=15.9,6.8 \mathrm{~Hz}, 1 \mathrm{H}\right), 5.81$ (d, $\left.J=15.9,1 \mathrm{H}\right), 4.18$ (q, $J=7.1 \mathrm{~Hz}$, 2H), 4.04-4.01 (m, 1H), 3.64 (t, $J=6.1 \mathrm{~Hz}, 2 \mathrm{H}), 2.58-2.46$ (m, 1H), 2.20-2.02 (m, 2H), 1.73-1.52 (m, 2H), $1.27(\mathrm{t}, J=7.1 \mathrm{~Hz}, 3 \mathrm{H}), 1.10-1.02(\mathrm{~m}, 15 \mathrm{H}), 0.92-0.82(\mathrm{~m}, 11 \mathrm{H}), 0.03(\mathrm{~s}, 6 \mathrm{H}) ;{ }^{13} \mathrm{C}$ NMR $\left(75 \mathrm{MHz}, \mathrm{CDCl}_{3}\right) \delta 166.5,151.3,121.3,126-105\left(\mathrm{~m}, \mathrm{C}_{8} \mathrm{~F}_{17}\right), 72.9,60.2,59.4,41.5,36.9$, 25.8 (3C), 25.5 (m, $\mathrm{CH}_{2} \mathrm{C}_{8} \mathrm{~F}_{17}$ ), 18.1, 17.6 (4C), 14.1, 13.2, 12.9 (2C), 0.9, -5.5 (2C); ${ }^{19} \mathrm{~F}$ NMR $\left(282 \mathrm{MHz}, \mathrm{CDCl}_{3}\right) \delta-79.6(3 \mathrm{~F}),-115.4(2 \mathrm{~F}),-120.7(6 \mathrm{~F}),-121.5(2 \mathrm{~F}),-122.0(2 \mathrm{~F}),-124.9$ (2F); MS (ESI) $m / z 899.3[\mathrm{M}+\mathrm{Na}]^{+}$; HRMS (ESI) calcd for $\mathrm{C}_{32} \mathrm{H}_{49} \mathrm{O}_{4} \mathrm{~F}_{17} \mathrm{Si}_{2} \mathrm{Na}[\mathrm{M}+\mathrm{Na}]^{+}$ 899.2796, found 899.2744.

\section{Four-component mixture of (2E)-7-(tert-butyldimethylsilyloxy)-5-diisopropylperfluoro-} alkylethylsilyloxy-4-methylhept-2-en-1-ol:

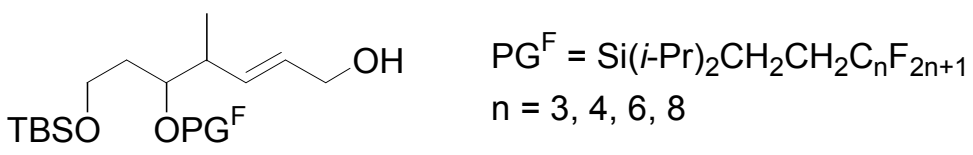


Compounds 12a (10.0 g, $\left.16.0 \mathrm{mmol}, \mathrm{C}_{3} \mathrm{~F}_{7}\right)$, 12b (7.45 g, 11.0 mmol, $\left.\mathrm{C}_{4} \mathrm{~F}_{9}\right)$, 12c $(8.55 \mathrm{~g}, 11.0$ mmol, $\left.\mathrm{C}_{6} \mathrm{~F}_{13}\right)$, and 12d $\left(14.0 \mathrm{~g}, 16.0 \mathrm{mmol}, \mathrm{C}_{8} \mathrm{~F}_{17}\right)$ were mixed and dissolved in $\mathrm{CH}_{2} \mathrm{Cl}_{2}(390$ $\mathrm{mL}$ ). The solution was cooled to $-78{ }^{\circ} \mathrm{C}$ and DIBAL (135 mL, $1.0 \mathrm{M}$ solution in hexanes, 135 mmol) was added dropwise within $45 \mathrm{~min}$. After stirring for $1 \mathrm{~h} 45 \mathrm{~min}$ at $-78{ }^{\circ} \mathrm{C}$, the reaction was quenched by addition of EtOAc $(30 \mathrm{~mL})$ and stirring for $15 \mathrm{~min}$. The solution was poured onto saturated aqueous Rochelle salt solution. The mixture was stirred for $4 \mathrm{~h}$ before the organic layer was separated and the aqueous layer was extracted with ether. The combined organic extracts were washed with brine, dried over $\mathrm{MgSO}_{4}$, and concentrated under reduced pressure. The crude material $\left(36.6 \mathrm{~g}, 97 \%{ }^{9}\right)$ was used without further purification.

\section{Four-component mixture of 12-perfluoroalkyl-9,9-diisopropyl-2,2,3,3-tetramethyl-} 7-[(2E)-1-methyl-4-trityloxybut-2-enyl]-4,8-dioxa-3,9-disiladodecane M-16a-d:

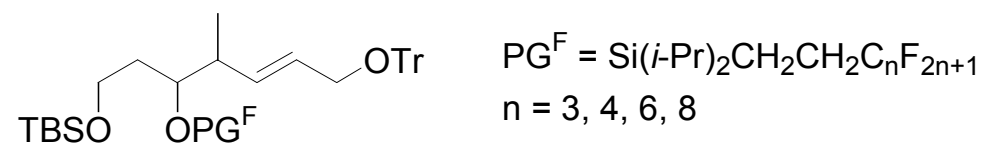

Trityl chloride (27.4 g, $98.3 \mathrm{mmol})$ and DMAP $(12.0 \mathrm{~g}, 98.3 \mathrm{mmol})$ were added to a solution of the above mixture $(32.8 \mathrm{~g}, 46.8 \mathrm{mmol})$ in pyridine $(500 \mathrm{~mL})$. The mixture was heated to reflux for $5 \mathrm{~h}$. Then, more trityl chloride $(6.90 \mathrm{~g}, 24.8 \mathrm{mmol})$ and DMAP (3.00 g, $24.6 \mathrm{mmol})$ were added and stirring continued for $1 \mathrm{~h}$ at reflux. Subsequently, the solvent was removed under reduced pressure and the residue was suspended in ether. The suspension was washed with saturated aqueous $\mathrm{CuSO}_{4}$ solution. The organic phase was dried over $\mathrm{MgSO}_{4}$ and concentrated under reduced pressure. The residue was purified by flash chromatography (EtOAc/hexanes 2:98) to give M-16a-d (41.0 g, 93\%).

\footnotetext{
${ }^{9}$ Calculation based on the average molecular weight of the mixture
} 


\section{Four-component mixture of (5E)-3-diisopropylperfluoroalkylethylsilyloxy-4-methyl-}

\section{7-trityloxyhept-5-en-1-ol:}

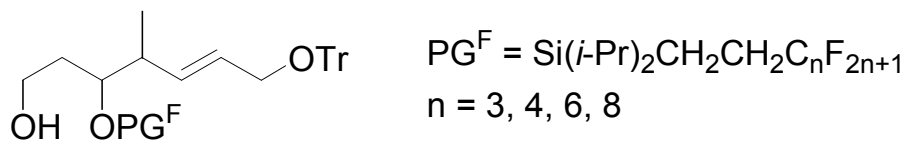

Hydrogen fluoride-pyridine complex in pyridine/THF (150 mL, prepared by slow addition of 42 $\mathrm{mL}$ pyridine to $10 \mathrm{~mL}$ pyridinium poly(hydrogen fluoride) $\left(70 \%\right.$ hydrogen fluoride) at $0{ }^{\circ} \mathrm{C}$ and dilution with $98 \mathrm{~mL}$ THF) was slowly added to a solution of the above alcohol $(39.2 \mathrm{~g}, 41.7$ $\mathrm{mmol})$ in THF $(100 \mathrm{~mL})$ at $0{ }^{\circ} \mathrm{C}$. The mixture was stirred at $0{ }^{\circ} \mathrm{C}$ for $20 \mathrm{~h}$. Then, the mixture was added dropwise to a saturated aqueous solution of $\mathrm{NaHCO}_{3}$ and the phases were separated. The aqueous phase was extracted with $\mathrm{CH}_{2} \mathrm{Cl}_{2}$. The combined organic phases were washed with a saturated aqueous solution of $\mathrm{CuSO}_{4}$, dried over $\mathrm{MgSO}_{4}$ and concentrated under reduced pressure. The residue was purified by flash chromatography (EtOAc/hexanes 10:90 to 20:80) to give the alcohol (18.7 g, 74\% brsm) along with recovered starting material (10.4 g, $11.0 \mathrm{mmol})$.

\section{Four-component mixture of (5E)-3-diisopropylperfluoroalkylethylsilyloxy-4-methyl-7- trityloxyhept-5-enal M-17a-d:}

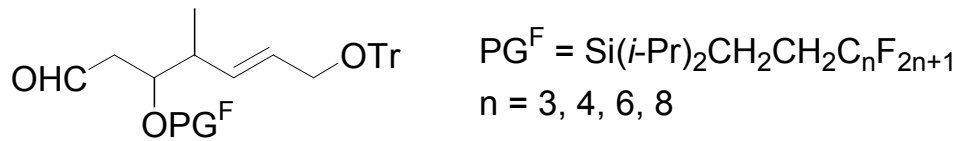

Dess-Martin periodinane $(14.4 \mathrm{~g}, 33.9 \mathrm{mmol})$ was added to a solution of the above alcohol (18.7 g, $22.6 \mathrm{mmol})$ in $\mathrm{CH}_{2} \mathrm{Cl}_{2}(300 \mathrm{~mL})$ at $0{ }^{\circ} \mathrm{C}$ and the mixture was left to warm to room temperature. After stirring at room temperature for $2 \mathrm{~h}$, the mixture was treated with a saturated aqueous solution of $\mathrm{NaHCO}_{3}(600 \mathrm{~mL})$ and the phases were separated. The aqueous phase was extracted with $\mathrm{CH}_{2} \mathrm{Cl}_{2}$. The combined organic extracts were dried over $\mathrm{MgSO}_{4}$ and concentrated under 
reduced pressure. The residue was purified by flash chromatography (EtOAc/hexanes 7:93) to give M-17a-d (16.4 g, 88\%).

\section{Four-component mixture of (5E)-3-diisopropylperfluoroalkylethylsilanyloxy-4-methyl-}

7-trityloxyhept-5-enoic acid methoxymethylamide M-8a-d:

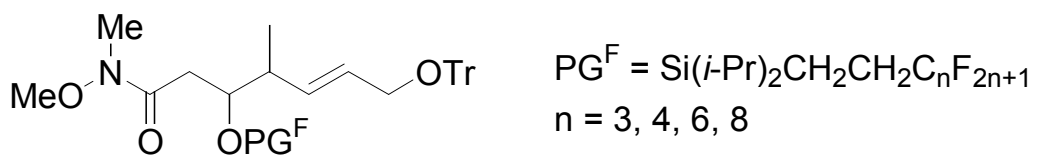

$\mathrm{NaH}_{2} \mathrm{PO}_{4} \mathrm{H}_{2} \mathrm{O}(932 \mathrm{mg}, 6.75 \mathrm{mmol})$ and 2-methyl-2-butene $(6.55 \mathrm{~mL}, 2.0 \mathrm{M}$ solution in THF, 13.1) were added to a solution of M-17a-d (1.86 g, $2.25 \mathrm{mmol})$ in THF (9 mL) and $\mathrm{H}_{2} \mathrm{O}(4 \mathrm{~mL})$. The mixture was cooled to $10{ }^{\circ} \mathrm{C}$ and $\mathrm{NaClO}_{2}$ (763 mg of technical grade material containing $80 \% \mathrm{NaClO}_{2}, 6.75 \mathrm{mmol}$ ) was added with vigorous stirring. The yellow solution was left to warm to room temperature and stirring continued for $1 \mathrm{~h}$. The mixture was diluted with $\mathrm{CH}_{2} \mathrm{Cl}_{2}$ (20 mL) and $\mathrm{H}_{2} \mathrm{O}(20 \mathrm{~mL})$ and the organic phase was separated. The aqueous phase was extracted with $\mathrm{CH}_{2} \mathrm{Cl}_{2}$. The combined organic extracts were dried over $\mathrm{MgSO}_{4}$ and concentrated under reduced pressure. $N, O$-Dimethylhydroxylamine hydrochloride (219 mg, $2.25 \mathrm{mmol}, \mathrm{Et}_{3} \mathrm{~N}$ (314 $\mu \mathrm{l}, 2.25 \mathrm{mmol})$, and DMAP $(27.5 \mathrm{mg}, 225 \mu \mathrm{mol})$ were added subsequently to a solution of the crude carboxylic acid in $\mathrm{CH}_{2} \mathrm{Cl}_{2}(7 \mathrm{~mL})$. The mixture was cooled to $0{ }^{\circ} \mathrm{C}$ and $\mathrm{DCC}(464 \mathrm{mg}$, $2.25 \mathrm{mmol}$ ) was added. The mixture was left to stir overnight at room temperature. Then, the mixture was concentrated under reduced pressure and the residue was purified by flash chromatography (EtOAc/hexanes 17:83) to give M-8a-d (1.46 g, 75\% over 2 steps).

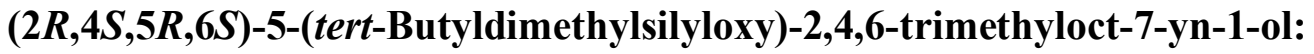



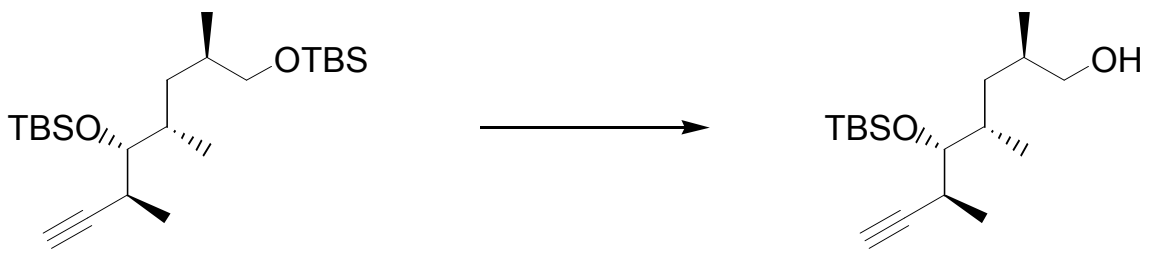

Hydrogen fluoride-pyridine complex in pyridine/THF $(5 \mathrm{~mL}$, stock solution prepared by slow addition of $12 \mathrm{~mL}$ pyridine to $3 \mathrm{~mL}$ pyridinium poly(hydrogen fluoride) (70\% hydrogen fluoride) at $0{ }^{\circ} \mathrm{C}$ and dilution with $30 \mathrm{~mL}$ THF) was slowly added to a solution of the indicated alkyne $^{10}(320 \mathrm{mg}, 0.775 \mathrm{mmol})$ in THF $(10 \mathrm{~mL})$ at $0{ }^{\circ} \mathrm{C}$. The mixture was stirred at room temperature for $24 \mathrm{~h}$ and quenched with saturated aqueous $\mathrm{NaHCO}_{3}$ solution. The aqueous phase was extracted with $\mathrm{CH}_{2} \mathrm{Cl}_{2}$ and the combined organic extracts were washed with brine, dried over $\mathrm{MgSO}_{4}$, and concentrated under reduced pressure. The residue was purified by flash chromatography (AcOEt/hexanes 1:5) to give the alcohol (204 mg, 88\%). $[\alpha]_{\mathrm{D}}^{20}-5.4(c 1.06$, $\mathrm{CHCl}_{3}$ ); IR (neat) 3312, 2929, 2857, 2114, 1463, 1251, $1069 \mathrm{~cm}^{-1} ;{ }^{1} \mathrm{H}$ NMR (300 MHz, $\mathrm{CDCl}_{3}$ )

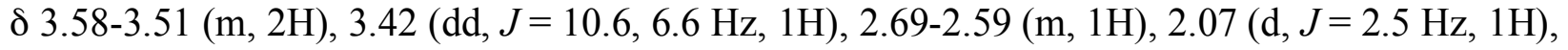
1.93-1.81 (m, 1H), 1.79-1.66 (m, 1H), 1.51 (quintet, $J=6.9 \mathrm{~Hz}, 1 \mathrm{H}), 1.44$ (br s, 1H), 1.19 (d, $J=$ $7.1 \mathrm{~Hz}, 3 \mathrm{H}), 0.97$ (d, $J=7.4 \mathrm{~Hz}, 3 \mathrm{H}), 0.92-0.90(\mathrm{~m}, 12 \mathrm{H}), 0.10$ (s, 3H), 0.08 (s, 3H); ${ }^{13} \mathrm{C}$ NMR $\left(75 \mathrm{MHz}, \mathrm{CDCl}_{3}\right) \delta$ 88.2, 78.0, 70.8, 68.6, 39.2, 34.4, 33.9, 32.5, 26.8 (3C), 19.1, 18.2, 18.0, 16.4, -3.3 (2C); MS (EI) $m / z 299[\mathrm{M}+\mathrm{H}]^{+}$; HRMS (EI) calcd for $\mathrm{C}_{17} \mathrm{H}_{35} \mathrm{O}_{2} \mathrm{Si}[\mathrm{M}+\mathrm{H}]^{+}$299.2406, found 299.2393 .

$(5 R, 6 S, 8 R)-11,11-D i e t h y l-2,2,3,3,6,8-h e x a m e t h y l-5-[(1 S)$-1-methylprop-2-ynyl]-4,10-dioxa-3, 11-disilatridecane 7:

${ }^{10}$ Shin, Y.; Fournier, J-H.; Fukui, Y.; Brückner, A. M.; Curran, D. P. Angew. Chem., Int. Ed. Engl. 2004, 43, 4634-4637. 


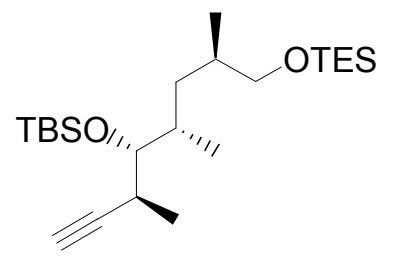

To a solution of the above alcohol $(11.6 \mathrm{~g}, 38.9 \mathrm{mmol})$ and imidazole $(5.83 \mathrm{~g}, 85.6 \mathrm{mmol})$ in $\mathrm{CH}_{2} \mathrm{Cl}_{2}(110 \mathrm{~mL})$ was added a solution of triethylsilyl chloride $(8.22 \mathrm{~g}, 54.5 \mathrm{mmol})$ in $\mathrm{CH}_{2} \mathrm{Cl}_{2}(6$ $\mathrm{mL}$ ) at $0{ }^{\circ} \mathrm{C}$. The mixture was stirred at $0{ }^{\circ} \mathrm{C}$ for $2 \mathrm{~h}$ and poured onto a saturated aqueous $\mathrm{NaHCO}_{3}$ solution at $0{ }^{\circ} \mathrm{C}$. The aqueous phase was extracted with $\mathrm{CH}_{2} \mathrm{Cl}_{2}$ and combined organic extracts were washed with brine, dried over $\mathrm{MgSO}_{4}$, and concentrated under reduced pressure. The residue was purified by flash chromatography (AcOEt/hexanes 2:98) to give the protected alcohol 7 (15.8 g, 98\%). $[\alpha]_{\mathrm{D}}{ }^{20}-8.3\left(c 1.08, \mathrm{CHCl}_{3}\right)$; IR (neat) 3313, 2935, 2878, 2114, 1462, 1252, $1087 \mathrm{~cm}^{-1} ;{ }^{1} \mathrm{H}$ NMR (300 MHz, $\left.\mathrm{CDCl}_{3}\right) \delta$ 3.54-3.47 (m, 2H), $3.30(\mathrm{dd}, J=9.7,7.2 \mathrm{~Hz}$, 1H), 2.66-2.57 (m, 1H), $2.04(\mathrm{~d}, J=2.5 \mathrm{~Hz}, 1 \mathrm{H}), 1.90-1.82(\mathrm{~m}, 1 \mathrm{H}), 1.74-1.64(\mathrm{~m}, 1 \mathrm{H}), 1.48$ (quintet, $J=6.8 \mathrm{~Hz}, 1 \mathrm{H}), 1.18(\mathrm{~d}, J=7.9 \mathrm{~Hz}, 3 \mathrm{H}), 0.96(\mathrm{t}, J=8.0 \mathrm{~Hz}, 9 \mathrm{H}), 0.93-0.88(\mathrm{~m}, 15 \mathrm{H})$, $0.61(\mathrm{q}, J=8.0 \mathrm{~Hz}, 6 \mathrm{H}), 0.10(\mathrm{~s}, 3 \mathrm{H}), 0.08(\mathrm{~s}, 3 \mathrm{H}) ;{ }^{13} \mathrm{C} \mathrm{NMR}\left(75 \mathrm{MHz}, \mathrm{CDCl}_{3}\right) \delta$ 89.0, 77.7, 70.2, 68.3, 39.3, 33.9, 33.8, 32.3, 26.4 (3C), 18.7, 18.0, 17.6, 15.9, 7.1 (3C), 4.7 (3C), -3.7 (2C); MS (CI) $m / z 435[\mathrm{M}+\mathrm{Na}]^{+}$; HRMS (CI) calcd for $\mathrm{C}_{23} \mathrm{H}_{48} \mathrm{O}_{2} \mathrm{Si}_{2} \mathrm{Na}[\mathrm{M}+\mathrm{Na}]^{+}$435.3091, found 435.3102 .

Four-component mixture of $(2 E, 10 S, 11 R, 12 S, 14 R)$-11-(tert-butyldimethylsilanyloxy)-5diisopropylperfluoroalkylethylsilanyloxy-4,10,12,14-tetramethyl-15-triethylsilanyloxy-1trityloxypentadec-2-en-8-yn-7-one: 


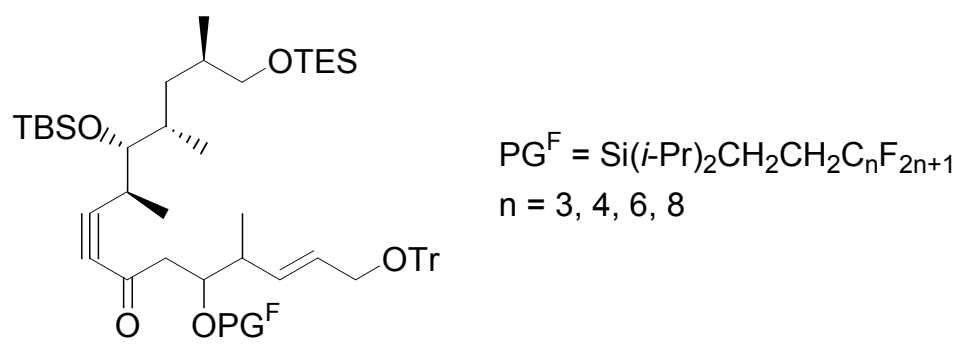

$n$-BuLi (18.8 mL, 1.6 M solution in hexane, $30.1 \mathrm{mmol})$ was added to a solution of alkyne 7 (12.4 g, $30.0 \mathrm{mmol})$ in $\mathrm{THF}(200 \mathrm{~mL})$ at $-78^{\circ} \mathrm{C}$. After stirring for $5 \mathrm{~min}$, the reaction mixture was warmed to $0{ }^{\circ} \mathrm{C}$ and stirred for $1 \mathrm{~h}$. The mixture was cooled back to $-78{ }^{\circ} \mathrm{C}$ and a solution of M-8a-d (13.3 g, $15.0 \mathrm{mmol})$ in THF (40 mL) was added. The resulting mixture was warmed to $0{ }^{\circ} \mathrm{C}$ and stirred for $1 \mathrm{~h}$. The mixture was poured onto a saturated aqueous $\mathrm{NH}_{4} \mathrm{Cl}$ solution and extracted with ether. The combined organic extracts were washed with brine, dried over $\mathrm{MgSO}_{4}$, and concentrated under reduced pressure. The residue was purified by flash chromatography $\left(\mathrm{CH}_{2} \mathrm{Cl}_{2} /\right.$ hexanes $1: 9$ to $\left.4: 1\right)$ to give the alkyne ketone $(16.3 \mathrm{~g}, 88 \%)$.

Four-component mixture of $(2 E, 7 S, 10 S, 11 R, 12 S, 14 R)$-11-(tert-butyldimethylsilanyloxy)-5-diisopropylperfluoroalkylethylsilanyloxy-4,10,12,14-tetramethyl-15-triethylsilanylox y-1-trityloxypentadec-2-en-8-yn-7-ol M-18a-d:

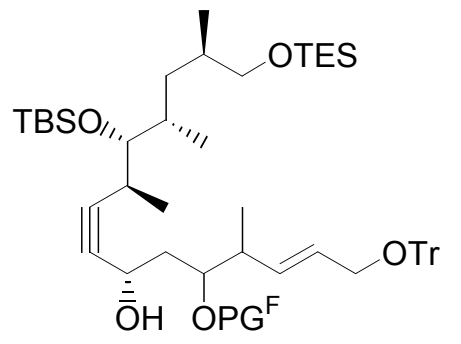

$$
\begin{aligned}
& \mathrm{PG}^{\mathrm{F}}=\mathrm{Si}(i-\mathrm{Pr})_{2} \mathrm{CH}_{2} \mathrm{CH}_{2} \mathrm{C}_{\mathrm{n}} \mathrm{F}_{2 \mathrm{n}+1} \\
& \mathrm{n}=3,4,6,8
\end{aligned}
$$

$\mathrm{Ru}\left[(1 S, 2 S)-p\right.$ - $\left.\mathrm{TsNHCH}\left(\mathrm{C}_{6} \mathrm{H}_{5}\right) \mathrm{CH}\left(\mathrm{C}_{6} \mathrm{H}_{5}\right) \mathrm{NH}\right]\left(\eta^{6}-p \text {-cymene }\right)^{11}(1.56 \mathrm{~g}, 2.60 \mathrm{mmol})$ was added to a solution of the above alkynyl ketone $(16.1 \mathrm{~g}, 13.0 \mathrm{mmol})$ in $i-\mathrm{PrOH}(130 \mathrm{~mL})$. The reaction

${ }^{11}$ a) Matsumura, K.; Hashiguchi, S.; Ikariya, T.; Noyori, R. J. Am. Chem. Soc. 1997, 119, 8738-8739. b) Haack, 
mixture was stirred at room temperature for $12 \mathrm{~h}$. The solvent was removed under reduced pressure, and the crude residue was purified by flash chromatography (AcOEt/hexanes 3:97) to give M-18a-d (15.2 g, 94\%).

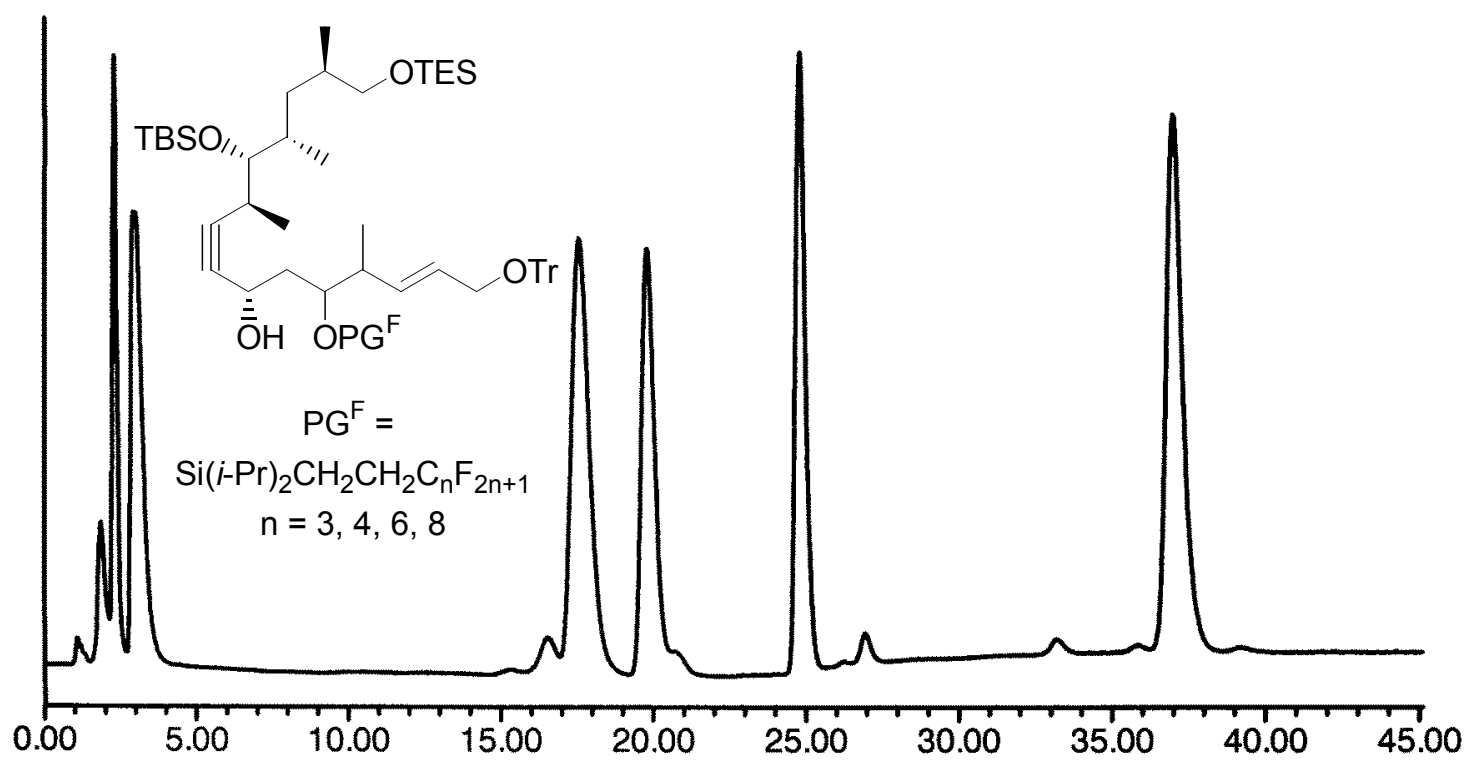

HPLC: FluoroFlash PF-C8 (Fluorous Technologies, Inc.) 4.6 x 150 mm, 100 A, $5 \mu \mathrm{m}$, UV detection at $230 \mathrm{~nm}$, gradient elution from 90:10 acetonitrile/ $\mathrm{H}_{2} \mathrm{O}$ to $100 \%$ acetonitrile in 20 min and isocratic acetonitrile for another $25 \mathrm{~min}$. 18a $\left(\mathrm{C}_{3} \mathrm{~F}_{7}\right)$ : $17.6 \mathrm{~min}, \mathbf{1 8 b}\left(\mathrm{C}_{4} \mathrm{~F}_{9}\right): 19.8 \mathrm{~min}, \mathbf{1 8 c}$ $\left(\mathrm{C}_{6} \mathrm{~F}_{13}\right): 24.8 \mathrm{~min}, \mathbf{1 8 d}\left(\mathrm{C}_{8} \mathrm{~F}_{17}\right): 37.0 \mathrm{~min} . \mathbf{1 8 a} / \mathbf{1 8 b} / \mathbf{1 8 c} / \mathbf{1 8 d}=1.4: 1.0: 1.1: 1.6$.

Four-component mixture of $(2 E, 7 S, 8 Z, 10 S, 11 R, 12 S, 14 R)-11$-(tert-butyldimethylsilanyloxy)-5-diisopropylperfluoroalkylethylsilanyloxy-4,10,12,14-tetramethyl-15-triethyl-silanylo xy-1-trityloxypentadeca-2,8-dien-7-ol:

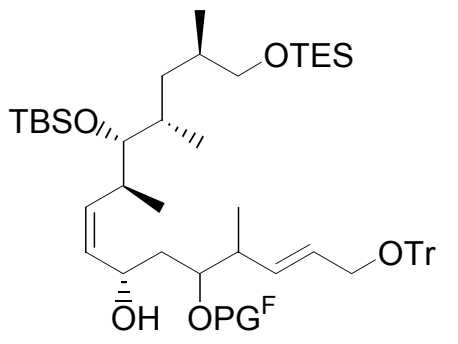

$\mathrm{PG}^{\mathrm{F}}=\mathrm{Si}(i-\mathrm{Pr})_{2} \mathrm{CH}_{2} \mathrm{CH}_{2} \mathrm{C}_{\mathrm{n}} \mathrm{F}_{2 \mathrm{n}+1}$

$\mathrm{n}=3,4,6,8$

K.-J.; Hashiguchi, S.; Fujii, A., Ikariya, T.; Noyori, R. Angew. Chem. Int. Ed. 1997, 36, 285-288. 
Lindlar catalyst ( $1.31 \mathrm{~g}, \mathrm{Pd}, 5 \%$ wt. on $\mathrm{CaCO}_{3}$, poisoned with lead) was added to a solution of M-18a-d $(6.57 \mathrm{~g}, 5.31 \mathrm{mmol})$ in toluene $(197 \mathrm{~mL})$. The mixture was vigorously stirred at room temperature for 30 min under a hydrogen atmosphere $(1 \mathrm{~atm})$. The reaction mixture was filtered through Celite, washed with ether, and concentrated under reduced pressure. The residue was purified by flash chromatography $\left(\mathrm{CH}_{2} \mathrm{Cl}_{2} /\right.$ hexanes $\left.2: 3\right)$ to give the alkynyl alcohol $(6.55 \mathrm{~g}$, $99 \%)$.

Four-component mixture of $(6 R, 8 S, 9 R, 10 S, 11 Z, 13 S)-9,13$-bis(tert-butyldimethylsilanyloxy)-3,3-diethyl-20-perfluoro-alkyl-17,17-diisopropyl-6,8,10-trimethyl-15-[(2E)-1-methyl-4trityloxybut-2-enyl]-4,16-dioxa-3,17-disilaicos-11-ene:

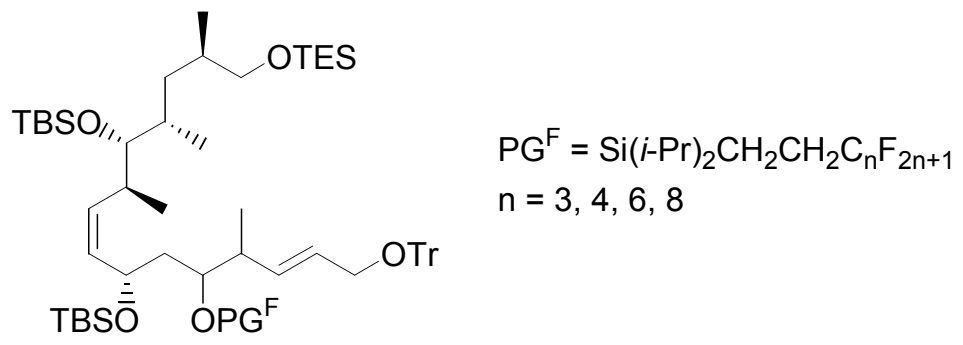

TBSOTf (5.9 $\mathrm{mL}, 25.7 \mathrm{mmol})$ was added to a solution of the above alkenyl alcohol (13.3 g, 10.7 mmol) and 2,6-lutidine $(6.0 \mathrm{~mL}, 51.5 \mathrm{mmol})$ in $\mathrm{CH}_{2} \mathrm{Cl}_{2}(267 \mathrm{~mL})$ at $0{ }^{\circ} \mathrm{C}$. After stirring for 30 min at $0{ }^{\circ} \mathrm{C}$, the reaction mixture was quenched with a saturated aqueous $\mathrm{NaHCO}_{3}$ solution and extracted with $\mathrm{CH}_{2} \mathrm{Cl}_{2}$. The combined organic extracts were washed with brine, dried over $\mathrm{MgSO}_{4}$, and concentrated under reduced pressure. The residue was purified by flash chromatography $\left(\mathrm{CH}_{2} \mathrm{Cl}_{2} /\right.$ hexanes 1:4) to give the silyl ether (13.9 g, 96\%).

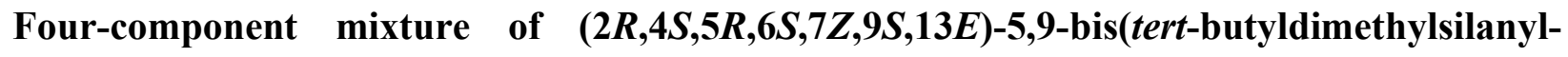 oxy)-11-diisopropylperfluoro-alkylethylsilanyloxy-2,4,6,12-tetramethyl-15-trityloxy-pentad eca-7,13-dien-1-ol M-19a-d:}




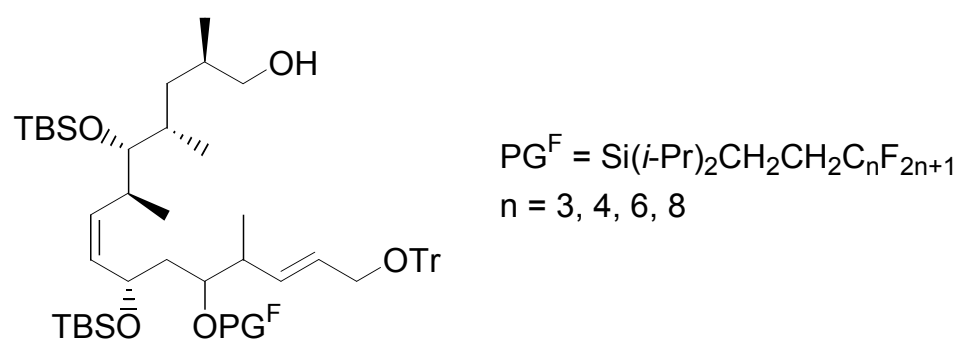

A solution of dichloroacetic acid $(7.07 \mathrm{~g}, 54.8 \mathrm{mmol})$ in $\mathrm{MeOH}(37 \mathrm{~mL})$ was added to a solution of the above silyl ether $(7.43 \mathrm{~g}, 5.49 \mathrm{mmol})$ in $\mathrm{CH}_{2} \mathrm{Cl}_{2}(137 \mathrm{~mL})$ and $\mathrm{MeOH}(100 \mathrm{~mL})$ at $0{ }^{\circ} \mathrm{C}$. After stirring for $1 \mathrm{~h}$ at $0{ }^{\circ} \mathrm{C}$, the reaction mixture was poured onto a saturated aqueous $\mathrm{NaHCO}_{3}$ solution and extracted with $\mathrm{CH}_{2} \mathrm{Cl}_{2}$. The combined organic extracts were washed with brine, dried over $\mathrm{MgSO}_{4}$, and concentrated under reduced pressure. The residue was purified by flash chromatography (AcOEt/hexanes 95:5 to 90:10) to give M-19a-d (6.13 g, 90\%). A sample was demixed by semipreparative HPLC ${ }^{12}$ (gradient elution from 90:10 acetonitrile/ $\mathrm{H}_{2} \mathrm{O}$ to $100 \%$ acetonitrile in $20 \mathrm{~min}$ and isocratic acetonitrile for another $100 \mathrm{~min}$ ) to give four fluorous alcohols: 19a $\left(\mathrm{C}_{3} \mathrm{~F}_{7}\right), 19 \mathbf{b}\left(\mathrm{C}_{4} \mathrm{~F}_{9}\right), 19 \mathbf{c}\left(\mathrm{C}_{6} \mathrm{~F}_{13}\right), \mathbf{1 9 d}\left(\mathrm{C}_{8} \mathrm{~F}_{17}\right)$.

19a $\left(\mathrm{C}_{3} \mathrm{~F}_{7}\right):{ }^{1} \mathrm{H} \mathrm{NMR}\left(300 \mathrm{MHz}, \mathrm{CDCl}_{3}\right) \delta$ 7.49-7.20 (m, $\left.15 \mathrm{H}\right), 5.56(\mathrm{~m}, 2 \mathrm{H}), 5.46(\mathrm{t}, J=10.6 \mathrm{~Hz}$, 1H), 5.27 (dd, $J=11.2,8.5 \mathrm{~Hz}, 1 \mathrm{H}), 4.60-4.51(\mathrm{~m}, 1 \mathrm{H}), 4.07-3.99(\mathrm{~m}, 1 \mathrm{H}), 3.59-3.49$ (m, 4H), 3.41-3.29 (m, 2H), 2.64-2.51 (m, 1H), 2.47-2.36 (m, 1H), 2.23-2.00 (m, $2 \mathrm{H}), 1.73-1.20(\mathrm{~m}, 8 \mathrm{H})$, 1.08 (s, 12H), 1.03-0.80 (m, 23H), 0.78 (s, 9H), 0.05 (s, 6H), 0.01 (s, 6H); MS (ESI) m/z 1147.8 $[\mathrm{M}+\mathrm{Na}]^{+}$; HRMS (ESI) calcd for $\mathrm{C}_{61} \mathrm{H}_{95} \mathrm{O}_{5} \mathrm{~F}_{7} \mathrm{Si}_{3} \mathrm{Na}[\mathrm{M}+\mathrm{Na}]^{+}$1147.6273, found 1147.6240.

19b $\left(\mathrm{C}_{4} \mathrm{~F}_{9}\right):{ }^{1} \mathrm{H}$ NMR $\left(300 \mathrm{MHz}, \mathrm{CDCl}_{3}\right) \delta$ 7.49-7.19 (m, 15H), $5.79(\mathrm{dd}, J=15.6,7.8 \mathrm{~Hz}, 1 \mathrm{H})$, $5.64(\mathrm{dt}, J=15.6,7.8 \mathrm{~Hz}, 1 \mathrm{H}), 5.34$ (t, $J=10.7 \mathrm{~Hz}, 1 \mathrm{H}), 5.18$ (dd, $J=11.2,7.6 \mathrm{~Hz}, 1 \mathrm{H}), 4.37$ (dd, $J=13.5,6.6 \mathrm{~Hz}, 1 \mathrm{H}), 4.08-4.01(\mathrm{~m}, 1 \mathrm{H}), 3.59-3.38(\mathrm{~m}, 4 \mathrm{H}), 3.25-3.14(\mathrm{~m}, 2 \mathrm{H}), 2.51-2.38$ (m, 1H), 2.35-2.23 (m, 1H), 2.22-2.02 (m, 2H), 1.67-1.20 (m, 8H), $1.14(\mathrm{~d}, J=6.6 \mathrm{~Hz}, 3 \mathrm{H})$, $1.11-0.70(\mathrm{~m}, 38 \mathrm{H}), 0.62(\mathrm{~d}, J=6.8 \mathrm{~Hz}, 3 \mathrm{H}), 0.02(\mathrm{~s}, 3 \mathrm{H}), 0.01(\mathrm{~s}, 6 \mathrm{H}),-0.01(\mathrm{~s}, 3 \mathrm{H})$; MS (ESI)

\footnotetext{
12 Semipreparative HPLC separations were carried out on a Waters HPLC system. The separation conditions were as follows: FluoroFlash HPLC column (Fluorous Technologies Inc., $20 \mathrm{~mm}$ x $250 \mathrm{~mm}$ ), flow rate of $10 \mathrm{~mL} / \mathrm{min}$. $\mathrm{UV}$ detection at $230 \mathrm{~nm}$ was used to manually identify peaks.
} 
$m / z 1197.8[\mathrm{M}+\mathrm{Na}]^{+}$; HRMS (ESI) calcd for $\mathrm{C}_{62} \mathrm{H}_{95} \mathrm{O}_{5} \mathrm{~F}_{9} \mathrm{Si}_{3} \mathrm{Na}[\mathrm{M}+\mathrm{Na}]^{+}$1197.6241, found 1197.6190.

19c $\left(\mathrm{C}_{6} \mathrm{~F}_{13}\right):{ }^{1} \mathrm{H}$ NMR $\left(300 \mathrm{MHz}, \mathrm{CDCl}_{3}\right) \delta$ 7.50-7.19 (m, 15H), $5.77(\mathrm{dd}, J=15.6,6.0 \mathrm{~Hz}, 1 \mathrm{H})$, 5.63-5.54 (m, 1H), $5.44(\mathrm{t}, J=10.8 \mathrm{~Hz}, 1 \mathrm{H}), 5.26(\mathrm{dd}, J=11.3,8.6 \mathrm{~Hz}, 1 \mathrm{H}), 4.57-4.51(\mathrm{~m}, 1 \mathrm{H})$, 4.01-3.98 (m, 1H), 3.65-3.44 (m, 3H), 3.43-3.27 (m, 2H), 3.24-3.16 (m, 1H), 2.61-2.38 (m, 2H), 2.25-2.00 (m, 2H), 1.68-1.20 (m, 8H), 1.20-0.75 (m, 44H), $0.044(\mathrm{~s}, 3 \mathrm{H}), 0.037(\mathrm{~s}, 3 \mathrm{H}), 0.01(\mathrm{~s}$, $6 \mathrm{H}$ ); MS (ESI) m/z $1297.8[\mathrm{M}+\mathrm{Na}]^{+}$; HRMS (ESI) calcd for $\mathrm{C}_{64} \mathrm{H}_{95} \mathrm{O}_{5} \mathrm{~F}_{13} \mathrm{Si}_{3} \mathrm{Na}[\mathrm{M}+\mathrm{Na}]^{+}$ 1297.6177, found 1297.6161.

19d $\left(\mathrm{C}_{8} \mathrm{~F}_{17}\right):{ }^{1} \mathrm{H}$ NMR $\left(300 \mathrm{MHz}, \mathrm{CDCl}_{3}\right) \delta$ 7.49-7.19 (m, 15H), $5.83(\mathrm{dd}, J=15.5,7.1 \mathrm{~Hz}, 1 \mathrm{H})$, $5.58(\mathrm{dt}, J=15.5,5.2 \mathrm{~Hz}, 1 \mathrm{H}), 5.33-5.23(\mathrm{~m}, 2 \mathrm{H}), 4.45-4.35(\mathrm{~m}, 1 \mathrm{H}), 4.20-4.12(\mathrm{~m}, 1 \mathrm{H})$, 3.68-3.48 (m, 4H), 3.42-3.30 (m, 2H), 2.60-2.46 (m, 1H), 2.45-2.33 (m, 1H), 2.20-1.96 (m, 2H), 1.80-1.10 (m, 8H), 1.10-0.74 (m, 44H), $0.06(\mathrm{~s}, 3 \mathrm{H}), 0.05(\mathrm{~s}, 6 \mathrm{H}), 0.03(\mathrm{~s}, 3 \mathrm{H})$; MS (ESI) m/z $1397.8[\mathrm{M}+\mathrm{Na}]^{+}$; HRMS (ESI) calcd for $\mathrm{C}_{66} \mathrm{H}_{95} \mathrm{O}_{5} \mathrm{~F}_{17} \mathrm{Si}_{3} \mathrm{Na}[\mathrm{M}+\mathrm{Na}]^{+}$1397.6114, found 1397.6075 .

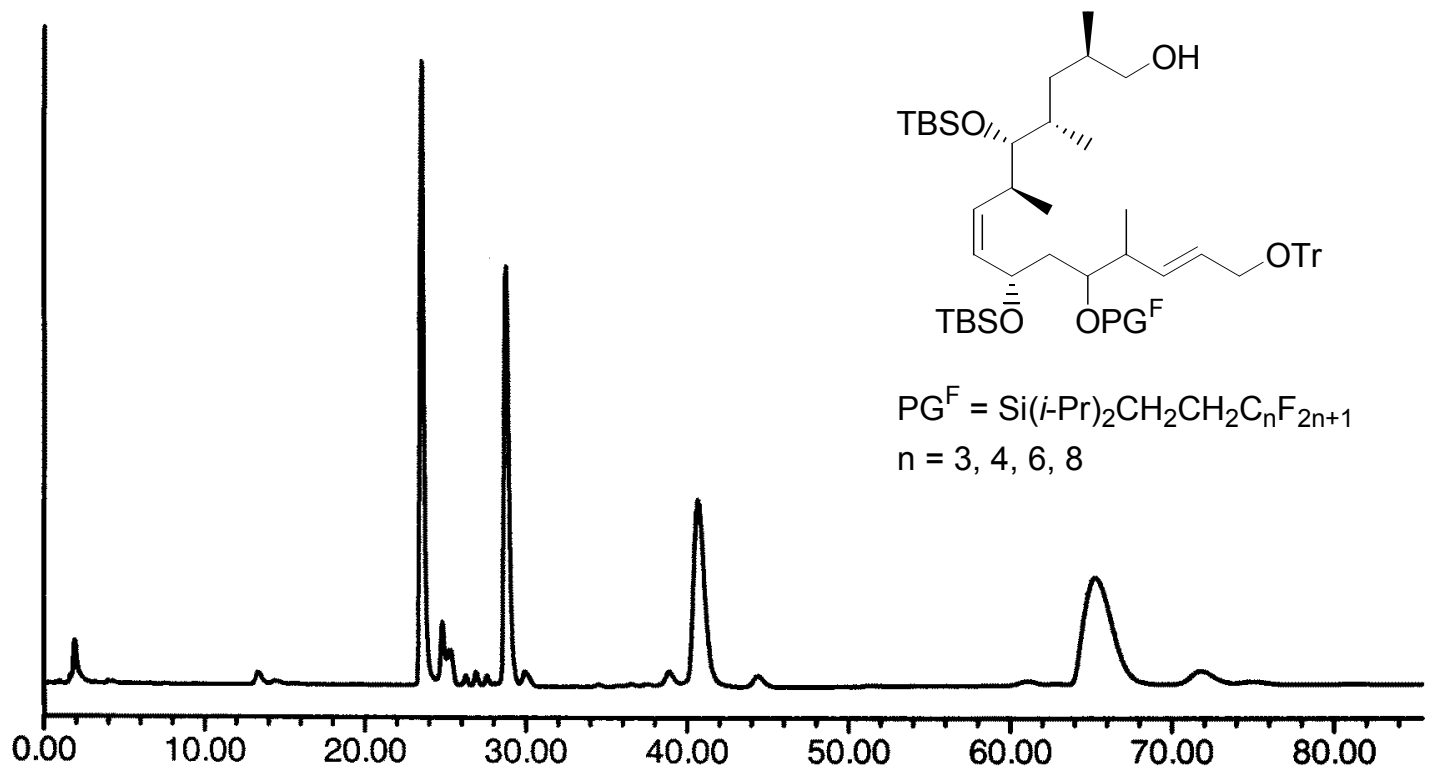

HPLC: FluoroFlash PF-C8 (Fluorous Technologies, Inc.) 4.6 x 150 mm, 100 A, 5 m, UV detection at $220 \mathrm{~nm}$, gradient elution from 90:10 acetonitrile $/ \mathrm{H}_{2} \mathrm{O}$ to $100 \%$ acetonitrile in $20 \mathrm{~min}$ and isocratic acetonitrile for another $70 \mathrm{~min}$. 19a $\left(\mathrm{C}_{3} \mathrm{~F}_{7}\right): 23.5 \mathrm{~min}, \mathbf{1 9 b}\left(\mathrm{C}_{4} \mathrm{~F}_{9}\right): 28.8 \mathrm{~min}, \mathbf{1 9 c}$ $\left(\mathrm{C}_{6} \mathrm{~F}_{13}\right): 40.7 \mathrm{~min}, \mathbf{1 9 d}\left(\mathrm{C}_{8} \mathrm{~F}_{17}\right): 65.3 \mathrm{~min} . \mathbf{1 9 a} / \mathbf{1 9 b} / \mathbf{1 9 c} / \mathbf{1 9 d}=1.3: 1.0: 1.0: 1.4$. 
Four-component mixture of $(2 E, 10 S, 11 R, 12 S, 14 R)-11,15$-bis(tert-butyldimethylsilanyloxy)-5-diisopropylperfluoroalkylethylsilanyloxy-4,10,12,14-tetramethyl-1-trityloxy-pentade c-2-en-8-yn-7-one:

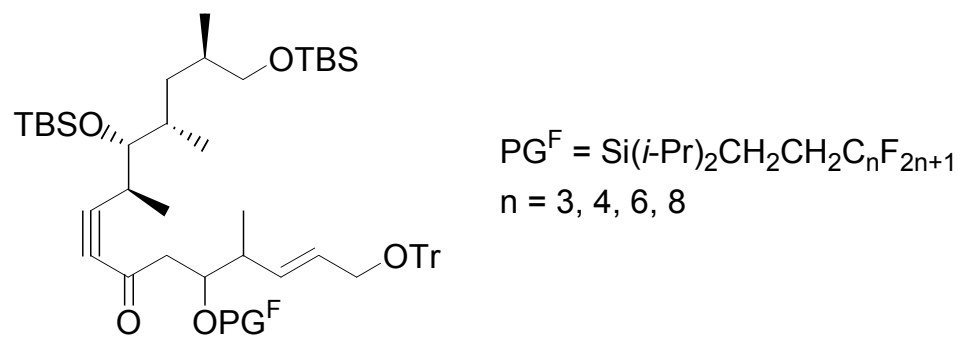

$n$-BuLi (1.4 mL, 1.6 M solution in hexane, $2.24 \mathrm{mmol})$ was added to a solution of alkyne 7 (TBS-ether variant, $930 \mathrm{mg}, 2.25 \mathrm{mmol})$ in THF $(15 \mathrm{~mL})$ at $-78^{\circ} \mathrm{C}$. After stirring for $5 \mathrm{~min}$, the reaction mixture was warmed to $0{ }^{\circ} \mathrm{C}$ and stirred for $30 \mathrm{~min}$. The mixture was cooled back to $-78{ }^{\circ} \mathrm{C}$ and a solution of M-8a-d $(996 \mathrm{mg}, 1.13 \mathrm{mmol})$ in THF $(3 \mathrm{~mL})$ was added. The resulting mixture was warmed to $0{ }^{\circ} \mathrm{C}$ and stirred for $1 \mathrm{~h}$. The mixture was poured onto saturated aqueous $\mathrm{NH}_{4} \mathrm{Cl}$ solution and extracted with ether. The combined organic extracts were washed with brine, dried over $\mathrm{MgSO}_{4}$, and concentrated under reduced pressure. The residue was purified by flash chromatography $\left(\mathrm{CH}_{2} \mathrm{Cl}_{2} /\right.$ hexanes $1: 9$ to $\left.4: 1\right)$ to give the alkynyl ketone $(1.25 \mathrm{~g}, 90 \%)$.

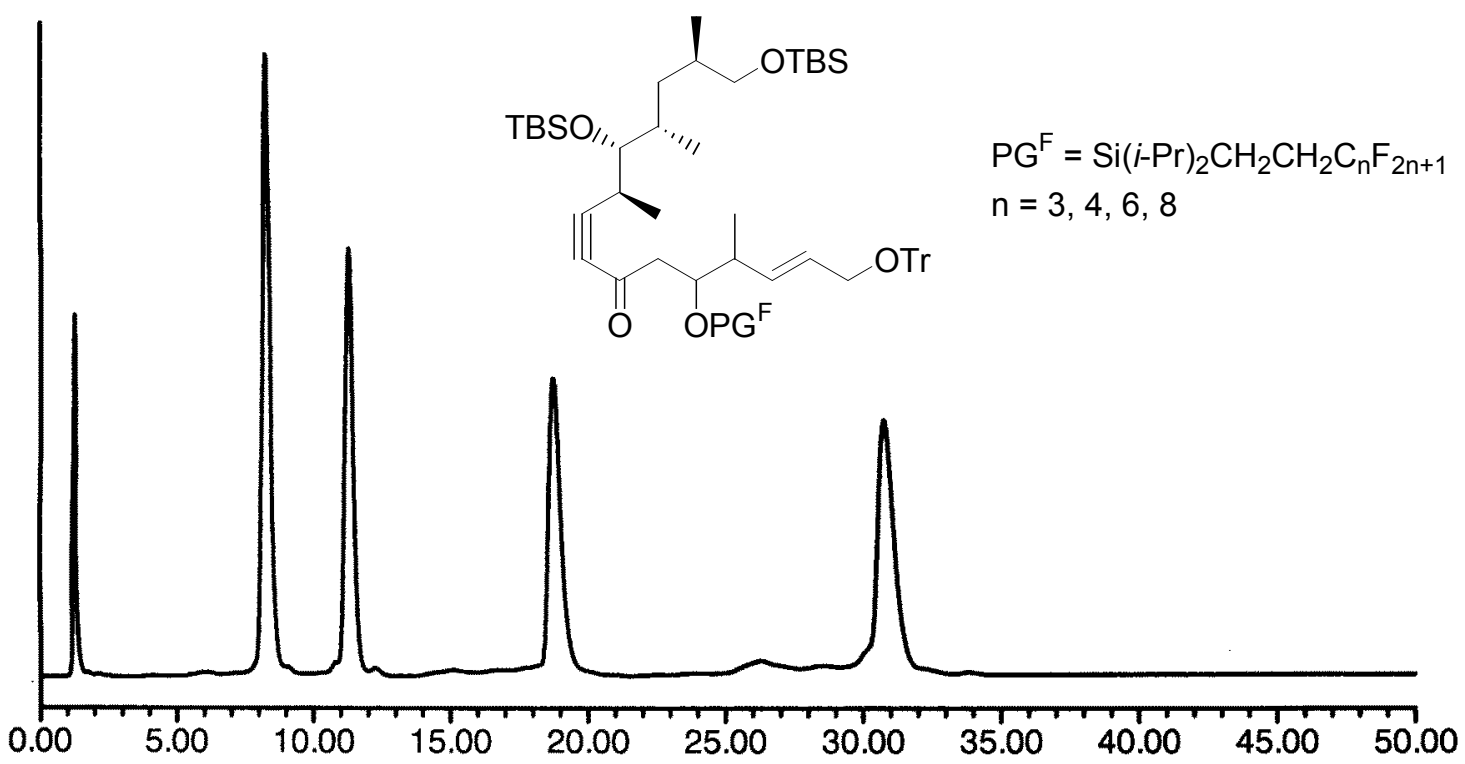


HPLC: FluoroFlash PF-C8 (Fluorous Technologies, Inc.) 4.6 x 150 mm, 100 A, 5 um, UV detection at $230 \mathrm{~nm}$, gradient elution from 90:10 acetonitrile $/ \mathrm{H}_{2} \mathrm{O}$ to $100 \%$ acetonitrile in $20 \mathrm{~min}$ and isocratic acetonitrile for another $30 \mathrm{~min}$. a $\left(\mathrm{C}_{3} \mathrm{~F}_{7}\right): 8.2 \mathrm{~min}, \mathbf{b}\left(\mathrm{C}_{4} \mathrm{~F}_{9}\right): 11.3 \mathrm{~min}, \mathbf{c}\left(\mathrm{C}_{6} \mathrm{~F}_{13}\right)$ : $18.7 \mathrm{~min}, \mathbf{d}\left(\mathrm{C}_{8} \mathrm{~F}_{17}\right): 30.7 \mathrm{~min} . \mathbf{a} / \mathbf{b} / \mathbf{c} / \mathbf{d}=1.4: 1.0: 1.0: 1.1$.

Four-component mixture of $(2 E, 7 S, 10 S, 11 R, 12 S, 14 R)-11,15$-bis(tert-butyldimethylsilanyloxy)-5-diisopropyl-perfluoroalkylethylsilanyloxy-4,10,12,14-tetramethyl-1-trityloxyp entadec-2-en-8-yn-7-ol M-18a-d (TBS ether variant):

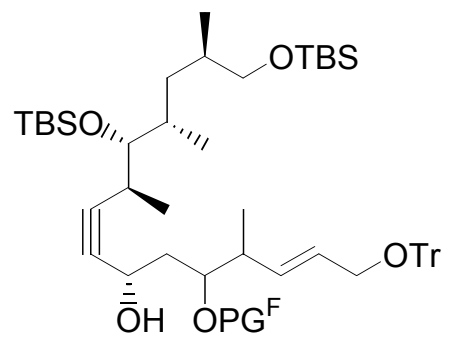

$$
\begin{aligned}
& \mathrm{PG}^{\mathrm{F}}=\mathrm{Si}(i-\mathrm{Pr})_{2} \mathrm{CH}_{2} \mathrm{CH}_{2} \mathrm{C}_{\mathrm{n}} \mathrm{F}_{2 \mathrm{n}+1} \\
& \mathrm{n}=3,4,6,8
\end{aligned}
$$

$\mathrm{Ru}\left[(1 S, 2 S)-p\right.$-TsNHCH$\left.\left(\mathrm{C}_{6} \mathrm{H}_{5}\right) \mathrm{CH}\left(\mathrm{C}_{6} \mathrm{H}_{5}\right) \mathrm{NH}\right]\left(\eta^{6}-p \text {-cymene }\right)^{13}(130 \mathrm{mg}, 0.217 \mathrm{mmol})$ was added to a solution of the alkynyl ketone $(1.21 \mathrm{~g}, 0.979 \mathrm{mmol})$ in $i-\mathrm{PrOH}(9.8 \mathrm{~mL})$. The reaction mixture was stirred at room temperature for $14 \mathrm{~h}$. The solvent was removed under reduced pressure, and the crude residue was purified by flash chromatography (AcOEt/hexanes 3:97) to give M-18a-d (TBS ether variant) (1.15 g, 94\%).

${ }^{13}$ a) Matsumura, K.; Hashiguchi, S.; Ikariya, T.; Noyori, R. J. Am. Chem. Soc. 1997, 119, 8738-8739. b) Haack, K.-J.; Hashiguchi, S.; Fujii, A., Ikariya, T.; Noyori, R. Angew. Chem. Int. Ed. 1997, 36, 285-288. 


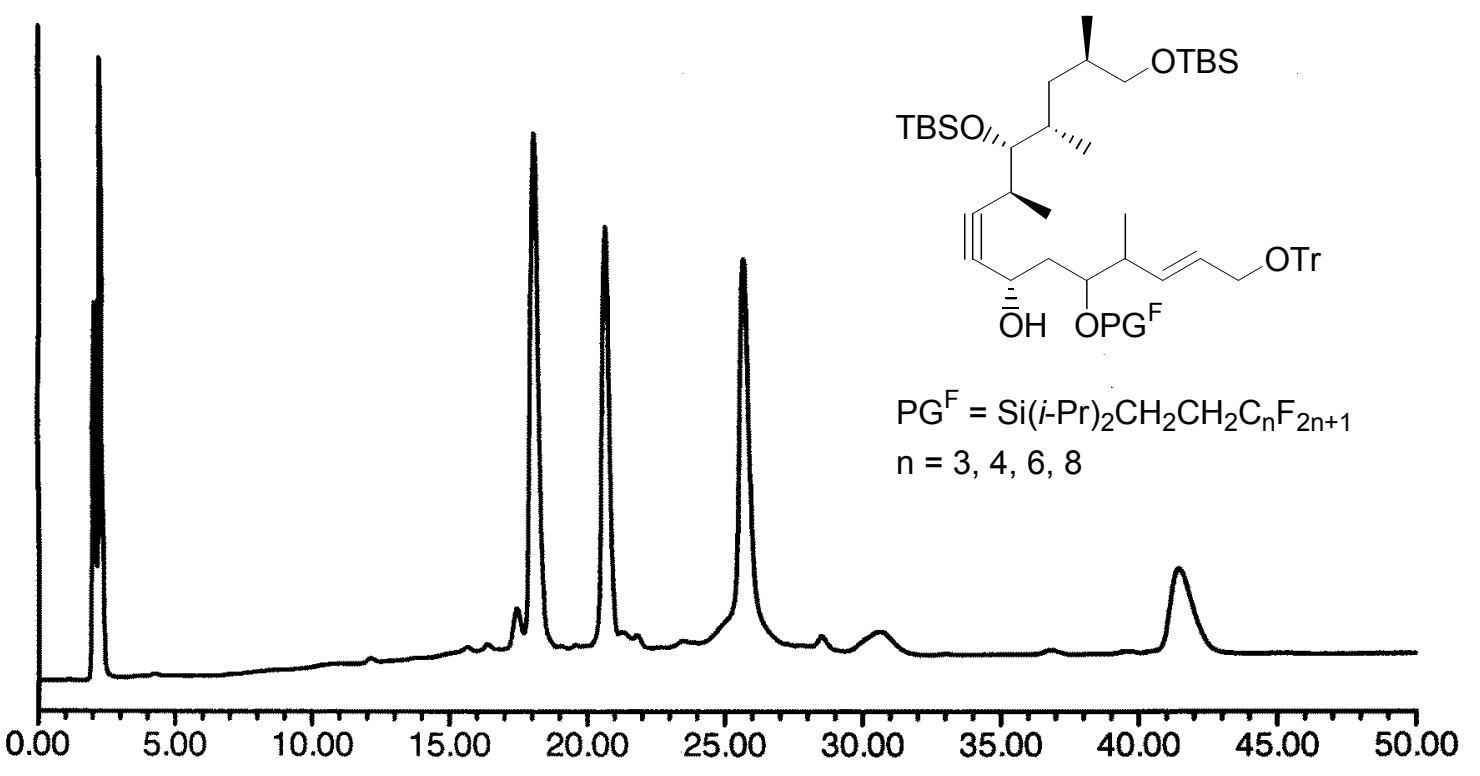

HPLC: FluoroFlash PF-C8 (Fluorous Technologies, Inc.) 4.6 x $150 \mathrm{~mm}, 100 \mathrm{~A}, 5 \mu \mathrm{m}$, UV detection at $220 \mathrm{~nm}$, gradient elution from 90:10 acetonitrile $/ \mathrm{H}_{2} \mathrm{O}$ to $100 \%$ acetonitrile in $20 \mathrm{~min}$ and isocratic acetonitrile for another $30 \mathrm{~min}$. a $\left(\mathrm{C}_{3} \mathrm{~F}_{7}\right)$ : $18.1 \mathrm{~min}, \mathbf{b}\left(\mathrm{C}_{4} \mathrm{~F}_{9}\right): 20.7 \mathrm{~min}, \mathbf{c}\left(\mathrm{C}_{6} \mathrm{~F}_{13}\right)$ : $25.7 \mathrm{~min}, \mathbf{d}\left(\mathrm{C}_{8} \mathrm{~F}_{17}\right): 41.5 \mathrm{~min} . \mathbf{a} / \mathbf{b} / \mathbf{c} / \mathbf{d}=2.3: 1.8: 2.5: 1.0$.

\section{Four-component mixture of $(2 E, 10 S, 11 R, 12 S, 14 R)-11,15$-bis(tert-butyldimethyl- silanyloxy)-5-diisopropyl-perfluoroalkylethylsilanyloxy-4,10,12,14-tetramethyl-1-trityloxyp entadec-2-en-8-yn-7-ol M-18a-d (TBS ether variant, mixture of C-7 epimers):}

An unselective reduction of the alkynyl ketone with $\mathrm{NaBH}_{4}$ in $\mathrm{MeOH}\left(-10{ }^{\circ} \mathrm{C}\right.$ to $\left.+5{ }^{\circ} \mathrm{C}\right)$ was performed in order to prove peak resolution of undesired epimers formed in the Noyori reduction from the desired stereoisomers: 


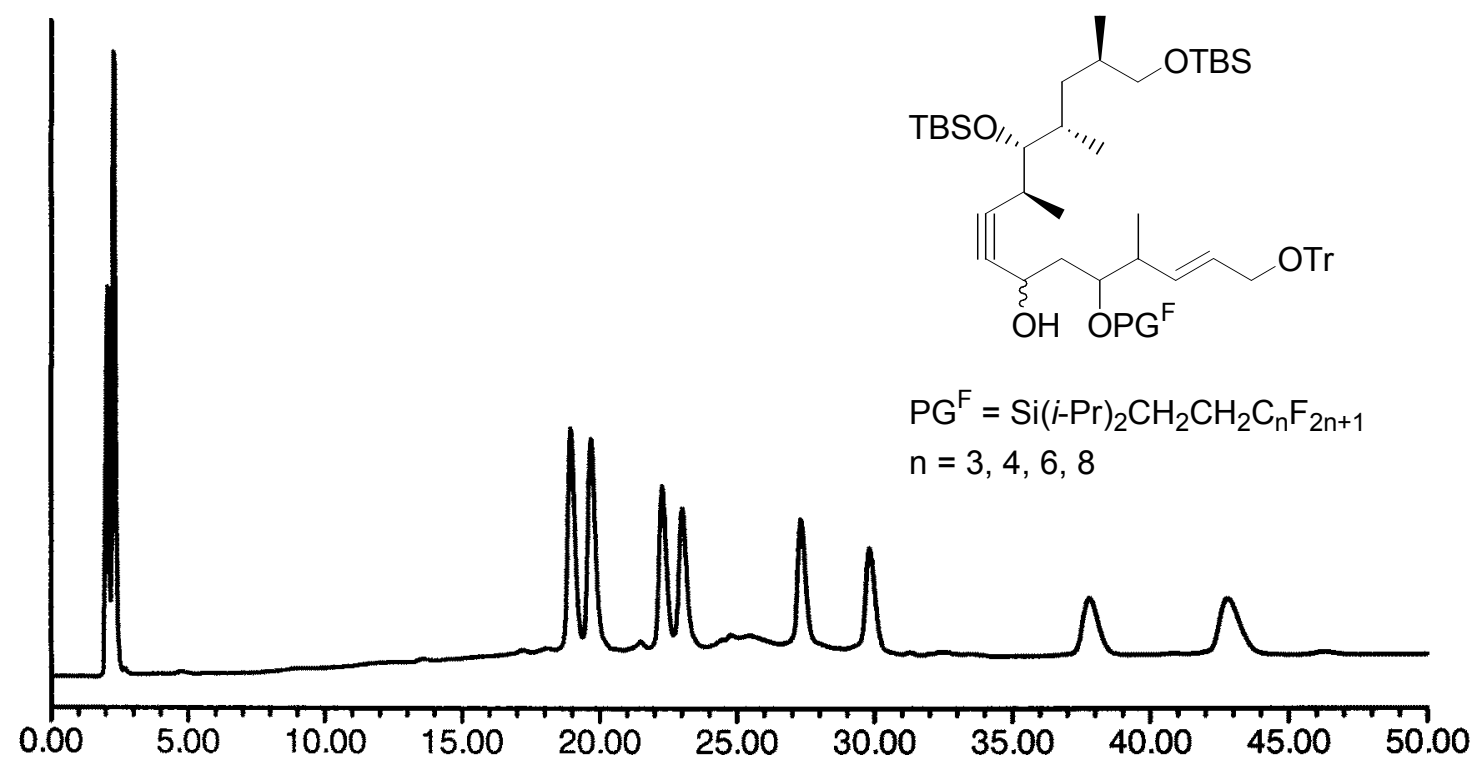

HPLC: FluoroFlash PF-C8 (Fluorous Technologies, Inc.) 4.6 x 150 mm, 100 A, 5 um, UV detection at $220 \mathrm{~nm}$, gradient elution from 90:10 acetonitrile $/ \mathrm{H}_{2} \mathrm{O}$ to $100 \%$ acetonitrile in $20 \mathrm{~min}$ and isocratic acetonitrile for another $30 \mathrm{~min}$. $\mathbf{a}\left(\mathrm{C}_{3} \mathrm{~F}_{7}\right): 19.0 / 19.7 \mathrm{~min}, \mathbf{b}\left(\mathrm{C}_{4} \mathrm{~F}_{9}\right): 22.3 / 23.0 \mathrm{~min}, \mathbf{c}$ $\left(\mathrm{C}_{6} \mathrm{~F}_{13}\right): 27.3 / 29.8 \mathrm{~min}, \mathbf{d}\left(\mathrm{C}_{8} \mathrm{~F}_{17}\right): 37.8 / 42.8 \mathrm{~min}$.

Four-component mixture of $(2 E, 7 S, 8 Z, 10 S, 11 R, 12 S, 14 R)-11,15$-bis(tert-butyldimethylsilanyloxy)-5-diisopropyl-perfluoroalkylethylsilanyloxy-4,10,12,14-tetramethyl-1-trityloxyp entadeca-2,8-dien-7-ol:

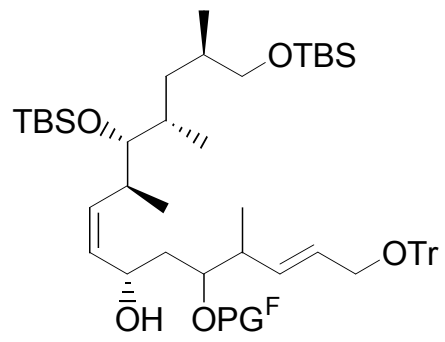

$$
\begin{aligned}
& \mathrm{PG}^{\mathrm{F}}=\mathrm{Si}(i-\mathrm{Pr})_{2} \mathrm{CH}_{2} \mathrm{CH}_{2} \mathrm{C}_{n} \mathrm{~F}_{2 \mathrm{n}+1} \\
& \mathrm{n}=3,4,6,8
\end{aligned}
$$

A solution of the alcohol M-18a-d $(575 \mathrm{mg}, 0.461 \mathrm{mmol})$ and Lindlar catalyst $(103 \mathrm{mg}, \mathrm{Pd}, 5 \%$ wt. on $\mathrm{CaCO}_{3}$, poisoned with lead) in toluene $(30 \mathrm{~mL})$ was vigorously stirred at room temperature for 45 min under a hydrogen atmosphere (1 atm). The reaction mixture was filtered 
through Celite, washed with ether, and concentrated under reduced pressure. The residue was purified by flash chromatography $\left(\mathrm{CH}_{2} \mathrm{Cl}_{2} /\right.$ hexanes $\left.2: 3\right)$ to give the alkene (572 $\left.\mathrm{mg}, 99 \%\right)$. A sample was demixed by semipreparative HPLC (gradient elution from 90:10 acetonitrile/ $\mathrm{H}_{2} \mathrm{O}$ to $100 \%$ acetonitrile in $20 \mathrm{~min}$ and isocratic acetonitrile for another $100 \mathrm{~min}$ ) to give four fluorous allylic alcohols: a $\left(\mathrm{C}_{3} \mathrm{~F}_{7}\right), \mathbf{b}\left(\mathrm{C}_{4} \mathrm{~F}_{9}\right), \mathbf{c}\left(\mathrm{C}_{6} \mathrm{~F}_{13}\right), \mathbf{d}\left(\mathrm{C}_{8} \mathrm{~F}_{17}\right)$.

a $\left(\mathrm{C}_{3} \mathrm{~F}_{7}\right):{ }^{1} \mathrm{H}$ NMR $\left(300 \mathrm{MHz}, \mathrm{CDCl}_{3}\right) \delta$ 7.46-7.19 (m, $\left.15 \mathrm{H}\right), 5.62(\mathrm{~m}, 2 \mathrm{H}), 5.49(\mathrm{t}, J=10.6 \mathrm{~Hz}$, 1H), $5.30(\mathrm{dd}, J=10.8,8.1 \mathrm{~Hz}, 1 \mathrm{H}), 4.63-4.52(\mathrm{~m}, 1 \mathrm{H}), 4.01(\mathrm{~m}, 1 \mathrm{H}), 3.56(\mathrm{~m}, 2 \mathrm{H}), 3.51-3.46$ (m, 1H), 3.38-3.33 (m, 1H), 3.28-3.20 (m, 1H), 2.73-2.63 (m, 1H), 2.53-2.42 (m, 1H), 2.27-2.03 (m, 2H), 1.72-1.17 (m, 8H), 1.12-0.72 (m, 44H), $0.02(\mathrm{~s}, 12 \mathrm{H}) .{ }^{19} \mathrm{~F}$ NMR $\left(282 \mathrm{MHz}, \mathrm{CDCl}_{3}\right) \delta$ $-79.4(3 \mathrm{~F}),-116.3(2 \mathrm{~F}),-126.3(2 \mathrm{~F})$.

b $\left(\mathrm{C}_{4} \mathrm{~F}_{9}\right):{ }^{1} \mathrm{H}$ NMR $\left(300 \mathrm{MHz}, \mathrm{CDCl}_{3}\right) \delta$ 7.54-7.18 (m, $\left.15 \mathrm{H}\right), 5.62(\mathrm{~m}, 2 \mathrm{H}), 5.43(\mathrm{t}, J=10.5 \mathrm{~Hz}$, $1 \mathrm{H}), 5.32(\mathrm{dd}, J=11.1,7.5 \mathrm{~Hz}, 1 \mathrm{H}), 4.45-4.37(\mathrm{~m}, 1 \mathrm{H}), 4.10-4.01(\mathrm{~m}, 1 \mathrm{H}), 3.54(\mathrm{~m}, 2 \mathrm{H})$, 3.46-3.41 (m, 1H), 3.31-3.19 (m, 2H), 2.71-2.60 (m, 1H), 2.51-2.40 (m, 1H), 2.26-2.04 (m, 2H), 1.73-1.21 (m, 8H), 1.15-0.79 (m, 41H), 0.73 (d, $J=6.7 \mathrm{~Hz}, 3 \mathrm{H}), 0.03$ (s, 3H), 0.02 (s, 3H), 0.00 (s, 3H), $-0.01(\mathrm{~s}, 3 \mathrm{H}) .{ }^{19} \mathrm{~F}$ NMR $\left(282 \mathrm{MHz}, \mathrm{CDCl}_{3}\right) \delta-79.8(3 \mathrm{~F}),-115.6(2 \mathrm{~F}),-123.0(2 \mathrm{~F})$, $-124.8(2 \mathrm{~F})$.

c $\left(\mathrm{C}_{6} \mathrm{~F}_{13}\right):{ }^{1} \mathrm{H}$ NMR $\left(300 \mathrm{MHz}, \mathrm{CDCl}_{3}\right) \delta 7.54-7.18(\mathrm{~m}, 15 \mathrm{H}), 5.81(\mathrm{dd}, J=6.1 \mathrm{~Hz}, 1 \mathrm{H})$, 5.66-5.55 (m, 1H), $5.47(\mathrm{t}, J=10.6 \mathrm{~Hz}, 1 \mathrm{H}), 5.31(\mathrm{dd}, J=11.2,8.0 \mathrm{~Hz}, 1 \mathrm{H}), 4.61-4.52(\mathrm{~m}, 1 \mathrm{H})$, 4.05-3.97 (m, 1H), 3.56 (d, $J=5.4 \mathrm{~Hz}, 2 \mathrm{H}), 3.44$ (dd, $J=9.7,4.7 \mathrm{~Hz}, 1 \mathrm{H}), 3.31$ (m, 1H), 3.22 (dd, $J=9.6,7.2 \mathrm{~Hz}, 1 \mathrm{H}), 2.70-2.60(\mathrm{~m}, 1 \mathrm{H}), 2.55-2.42(\mathrm{~m}, 1 \mathrm{H}), 2.29-2.03(\mathrm{~m}, 2 \mathrm{H}), 1.77-1.15(\mathrm{~m}$, 8H), 1.14-0.71 (m, 44H), 0.04 (s, 3H), 0.03 (s, 3H), 0.01 (s, 3H), 0.00 (s, 3H). ${ }^{19} \mathrm{~F}$ NMR $(282$ $\left.\mathrm{MHz}, \mathrm{CDCl}_{3}\right) \delta-79.5(3 \mathrm{~F}),-115.4(2 \mathrm{~F}),-120.7(2 \mathrm{~F}),-121.6(2 \mathrm{~F}),-122.0(2 \mathrm{~F}),-124.9(2 \mathrm{~F})$.

d $\left(\mathrm{C}_{8} \mathrm{~F}_{17}\right):{ }^{1} \mathrm{H}$ NMR $\left(300 \mathrm{MHz}, \mathrm{CDCl}_{3}\right) \delta$ 7.55-7.12 (m, 15H), 5.95-5.24 (m, 4H), $4.45(\mathrm{~m}, 1 \mathrm{H})$, $4.09(\mathrm{~m}, 1 \mathrm{H}), 3.60-3.55(\mathrm{~m}, 1 \mathrm{H}), 3.50-3.44(\mathrm{~m}, 2 \mathrm{H}), 3.36(\mathrm{~m}, 1 \mathrm{H}), 3.31-3.23(\mathrm{~m}, 1 \mathrm{H}), 2.72(\mathrm{~m}$, 1H), $2.46(\mathrm{~m}, 1 \mathrm{H}), 2.24-1.91(\mathrm{~m}, 2 \mathrm{H}), 1.8-0.7(\mathrm{~m}, 52 \mathrm{H}), 0.02(\mathrm{~s}, 12 \mathrm{H}) .{ }^{19} \mathrm{~F}$ NMR $(282 \mathrm{MHz}$, $\left.\mathrm{CDCl}_{3}\right) \delta-79.5(3 \mathrm{~F}),-115.4(2 \mathrm{~F}),-120.7(6 \mathrm{~F}),-121.5(2 \mathrm{~F}),-122.0(2 \mathrm{~F}),-124.9(2 \mathrm{~F})$. 


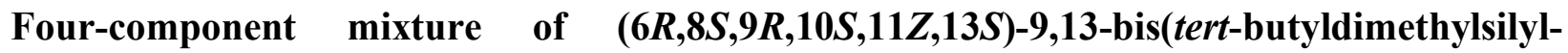
oxy)-20-perfluoroalkyl-17,17-diisopropyl-2,2,3,3,6,8,10-heptamethyl-15-[(2E)-1-methyl-4-tr ityloxybut-2-enyl]-4,16-dioxa-3,17-disilaicos-11-ene:

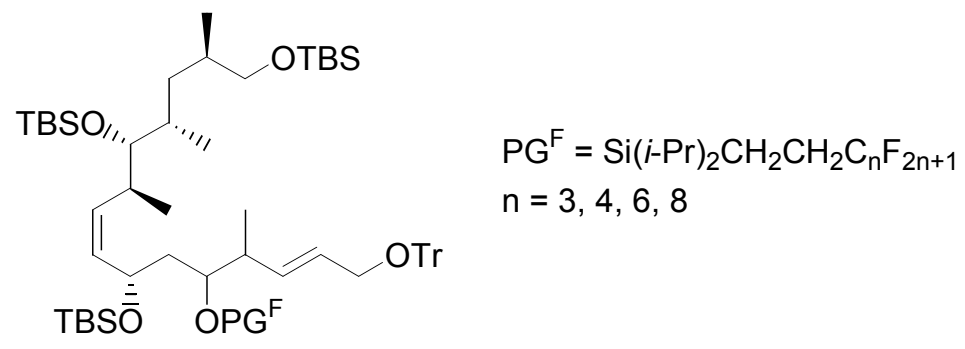

TBSOTf $(23 \mu \mathrm{l}, 100 \mu \mathrm{mol})$ was added to a solution of the above alkene $(51.0 \mathrm{mg}, 40.8 \mu \mathrm{mol})$ and 2,6-lutidine $(23 \mu \mathrm{l}, 197 \mu \mathrm{mol})$ in $\mathrm{CH}_{2} \mathrm{Cl}_{2}(1 \mathrm{~mL})$ at $0{ }^{\circ} \mathrm{C}$. After stirring for $30 \mathrm{~min}$ at $0{ }^{\circ} \mathrm{C}$, the reaction mixture was quenched with phosphate buffer $\mathrm{pH} 7$ and extracted with $\mathrm{CH}_{2} \mathrm{Cl}_{2}$. The combined organic extracts were washed with brine, dried over $\mathrm{MgSO}_{4}$, and concentrated under reduced pressure. The residue was purified by flash chromatography $\left(\mathrm{CH}_{2} \mathrm{Cl}_{2} /\right.$ hexanes $\left.1: 4\right)$ to give the silyl ether (52.3 mg, 94\%).

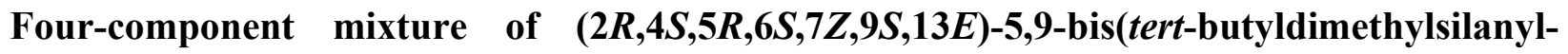
oxy)-11-diisopropyl-perfluoroalkylethylsilanyloxy-2,4,6,12-tetramethyl-15-trityloxy-pentad eca-7,13-dien-1-ol M-19a-d:
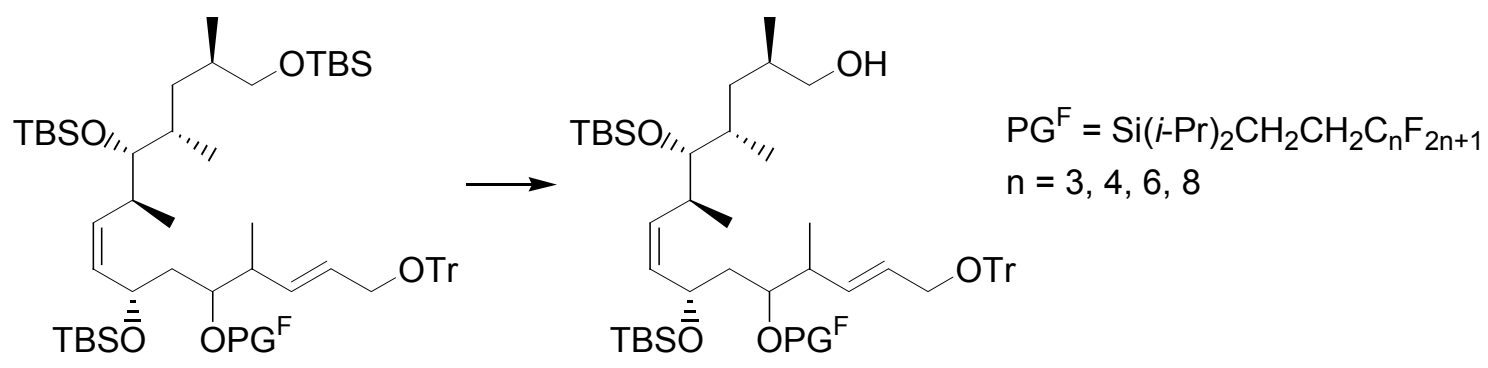

A solution of dichloroacetic acid $(280 \mathrm{mg}, 2.17 \mathrm{mmol})$ in $\mathrm{MeOH}(2 \mathrm{~mL})$ was added to a solution of the above silyl ether $(296 \mathrm{mg}, 217 \mu \mathrm{mol})$ in $\mathrm{CH}_{2} \mathrm{Cl}_{2}(12 \mathrm{~mL})$ and $\mathrm{MeOH}(10 \mathrm{~mL})$ at $-5{ }^{\circ} \mathrm{C}$. 
After stirring for $87 \mathrm{~h}$ at $-5{ }^{\circ} \mathrm{C}$, the reaction mixture was poured onto a saturated aqueous $\mathrm{NaHCO}_{3}$ solution and extracted with $\mathrm{CH}_{2} \mathrm{Cl}_{2}$. The combined organic extracts were washed with brine, dried over $\mathrm{MgSO}_{4}$, and concentrated under reduced pressure. The residue was purified by flash chromatography (AcOEt/hexanes 95:5 to 90:10) to give M-19a-d (168 mg, 62\%) along with recovered starting material (45 mg, 15\%).

Four-component mixture of $(3 Z, 5 S, 6 S, 7 R, 9 E, 11 R, 13 S, 14 R, 15 S, 16 Z, 18 S, 22 E)-14,18$-bis(tert-butyldimethylsilanyloxy)-20-diisopropylperfluoroalkylethylsilanyloxy-6-(4-methoxybe nzyloxy)-5,7,11,13,15,21-hexamethyl-23-trityloxytricosa-1,3,9,16,22-pentaen-8-one:
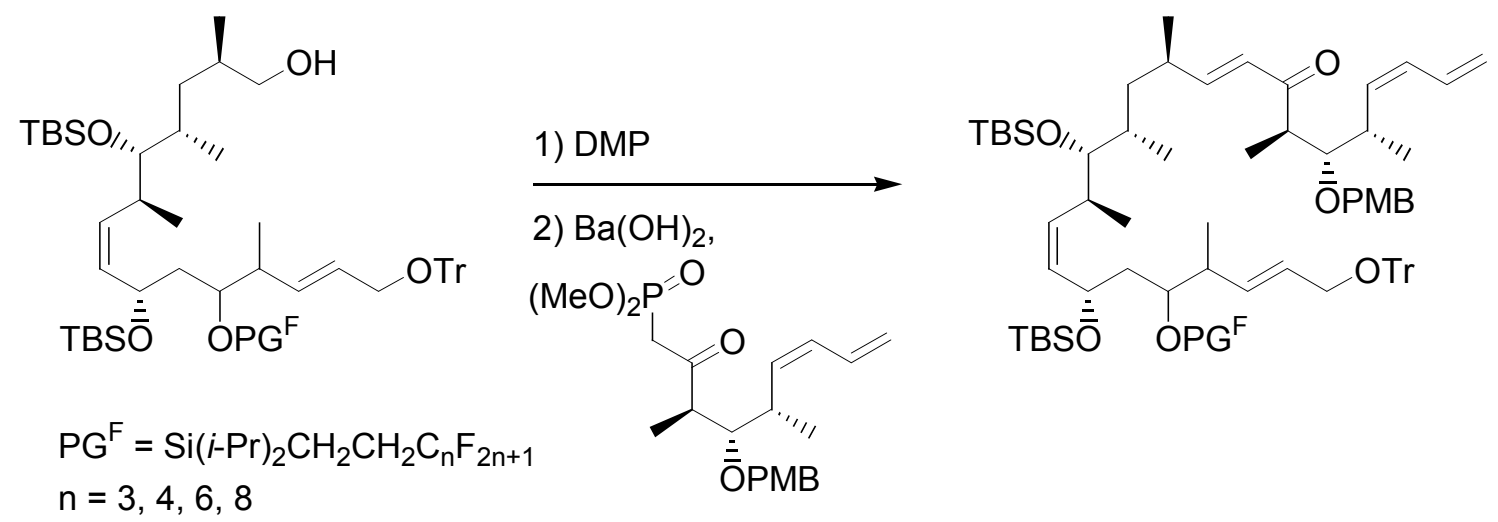

Dess-Martin periodinane (1.02 g, $2.40 \mathrm{mmol})$ was added to a solution of alcohol M-19a-d (2.00 g, $1.61 \mathrm{mmol})$ in $\mathrm{CH}_{2} \mathrm{Cl}_{2}(54 \mathrm{~mL})$ at $0{ }^{\circ} \mathrm{C}$. After stirring for $1 \mathrm{~h}$, more Dess-Martin periodinane (510 $\mathrm{mg}, 1.20 \mathrm{mmol}$ ) was added and stirring continued for $1 \mathrm{~h}$ at room temperature. The mixture was poured onto saturated aqueous $\mathrm{NaHCO}_{3}$ at $0{ }^{\circ} \mathrm{C}$ and extracted with $\mathrm{CH}_{2} \mathrm{Cl}_{2}$. The combined organic extracts were washed with brine, dried over $\mathrm{MgSO}_{4}$, and concentrated under reduced pressure. The residue was purified by flash chromatography (short package of silica gel, $\mathrm{AcOEt} / \mathrm{hexanes} 5: 95)$ to give a mixture of the corresponding crude aldehydes (2.08 g), which was used for the next reaction without further purification. A mixture of ketophosphonate $\mathbf{6}^{14}$

\footnotetext{
${ }^{14}$ Paterson, I.; Britton, R.; Delgado, O.; Meyer, A.; Poullennec, K. G. Angew. Chem. Int. Ed. 2004, 43, 4629-4633.
} 
(793 mg, $1.93 \mathrm{mmol})$ and $\mathrm{Ba}(\mathrm{OH})_{2} \cdot 8 \mathrm{H}_{2} \mathrm{O}\left(265 \mathrm{mg}\right.$, activated by heating to $120{ }^{\circ} \mathrm{C}$ before use) in THF $(18 \mathrm{~mL})$ was stirred at room temperature for $30 \mathrm{~min}$. A solution of the aldehyde $(2.08 \mathrm{~g})$ in wet THF $\left(18 \mathrm{~mL}, 40: 1 \mathrm{THF} / \mathrm{H}_{2} \mathrm{O}\right)$ was then added and the reaction mixture was stirred at room temperature for $13 \mathrm{~h}$. The mixture was poured onto a saturated aqueous $\mathrm{NaHCO}_{3}$ solution and extracted with $\mathrm{CH}_{2} \mathrm{Cl}_{2}$. The combined organic extracts were washed with brine, dried over $\mathrm{MgSO}_{4}$, and concentrated under reduced pressure. The residue was purified by flash chromatography (AcOEt/hexanes 5:95) to give the unsaturated ketone $(2.03 \mathrm{~g}, 82 \%$ over 2 steps).

Four-component mixture of $(3 Z, 5 S, 6 S, 7 R, 11 S, 13 S, 14 R, 15 S, 16 Z, 18 S, 22 E)-14,18-b i s-$ (tert-butyldimethylsilanyloxy)-20-diisopropylperfluoroalkylethylsilanyloxy-6-(4-methoxy-b enzyloxy)-5,7,11,13,15,21-hexamethyl-23-trityloxytricosa-1,3,16,22-tetraen-8-one:

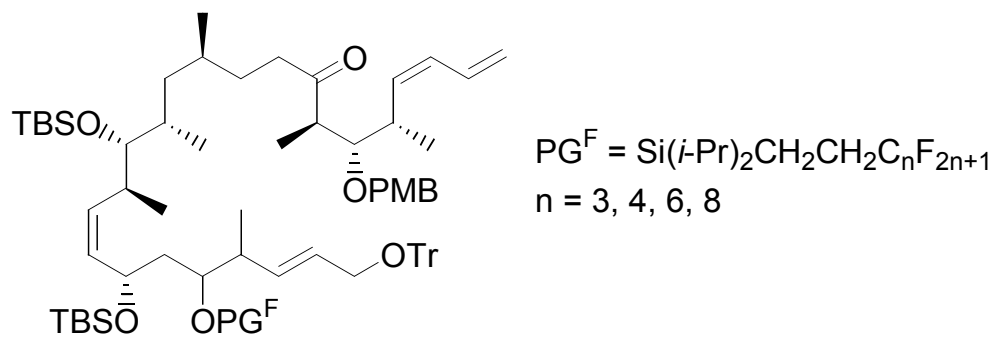

The reducing agent ${ }^{15}\left[\mathrm{PPh}_{3} \mathrm{CuH}\right]_{6}(2.60 \mathrm{~g}, 1.33 \mathrm{mmol})$ was added to a solution of the above unsaturated ketone $(2.02 \mathrm{~g}, 1.33 \mathrm{mmol})$ in toluene $(60 \mathrm{~mL})$ at room temperature under argon. After stirring for $1 \mathrm{~h}$, hexane $(20 \mathrm{~mL})$ was added, and the reaction mixture was exposed to air, stirred for $1 \mathrm{~h}$, and concentrated under reduced pressure. The residue was purified by flash chromatography (AcOEt/hexanes 3:97 to 12:88) to give the saturated ketone (1.95 g, 96\%).

15 (a) Mahoney, W. S.; Brestensky, D. M.; Stryker, J. M. J. Am. Chem. Soc. 1988, 110, 292-293. (b) Gaul, C.; Njardadarson, J. T. ; Shan, D. ; Dorn, D. C.; Wu, K-D.: Tong, W. P.; Huang, X-Y. ; Moore, M. A. S.; Danishefsky, S. J. J. Am. Chem. Soc. 2004, 126, 11326-11337. 
Four-component mixture of $(3 Z, 5 S, 6 S, 7 S, 8 S, 11 S, 13 S, 14 R, 15 S, 16 Z, 18 S, 22 E)-14,18$-Bis(tert-butyldimethylsilyloxy)-20-diisopropylperfluoroalkylethylsilyloxy-6-(4-methoxybenzyloxy)-5,7,11,13,15,21-hexamethyl-23-trityloxytricosa-1,3,16,22-tetraen-8-ol M-20a-d and $(3 Z, 5 S, 6 S, 7 S, 8 R, 11 S, 13 S, 14 R, 15 S, 16 Z, 18 S, 22 E)-14,18$-Bis(tert-butyldimethylsilyloxy)-20-diisopropylperfluoroalkylethylsilyloxy-6-(4-methoxybenzyloxy)-5,7,11,13,15,21-hex amethyl-23-trityloxytricosa-1,3,16,22-tetraen-8-ol M-21a-d:

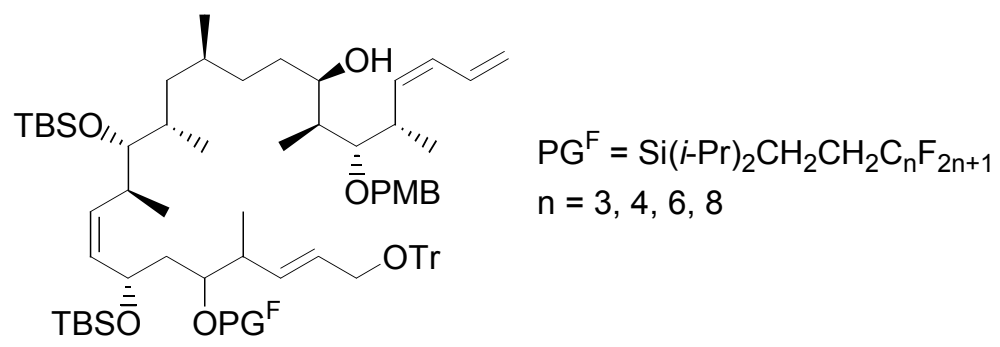

$\mathrm{LiAl}(\mathrm{Ot}-\mathrm{Bu})_{3} \mathrm{H}(3.0 \mathrm{~mL}, 1.0 \mathrm{M}$ solution in THF, $3.0 \mathrm{mmol})$ was added to a solution of the above saturated ketone $(229 \mathrm{mg}, 150 \mathrm{~mol})$ in THF $(7.5 \mathrm{~mL})$ at $-78{ }^{\circ} \mathrm{C}$. After stirring for $2 \mathrm{~h}$ at $-78^{\circ} \mathrm{C}$, the reaction mixture was warmed to room temperature and stirring continued for $14 \mathrm{~h}$. The reaction mixture was quenched with a saturated aqueous $\mathrm{NH}_{4} \mathrm{Cl}$ solution and stirred for $2 \mathrm{~h}$ at room temperature. The mixture was extracted with ether, and the combined organic extracts were washed with $\mathrm{H}_{2} \mathrm{O}$, dried over $\mathrm{MgSO}_{4}$, and concentrated under reduced pressure. The residue was purified by flash chromatography (ether/hexanes 8:92 to 12:88) to give the $\alpha$-alcohols 20a-d (103 mg, 45\%), the $\beta$-alcohols M-20a-d (23.4 mg, 10\%), and a mixture of both (49.8 $\mathrm{mg}, 22 \%$ ).

20a $\left(\mathrm{C}_{3} \mathrm{~F}_{7}\right):{ }^{1} \mathrm{H}$ NMR $\left(500 \mathrm{MHz}, \mathrm{CDCl}_{3}\right) \delta$ 7.47-7.43 (m, 5H), 7.31-7.20 (m, 12H), $6.83(\mathrm{~d}, J=$ $8.7 \mathrm{~Hz}, 2 \mathrm{H}), 6.67(\mathrm{dt}, J=17.0,10.5 \mathrm{~Hz}, 1 \mathrm{H}), 6.06(\mathrm{t}, J=10.5 \mathrm{~Hz}, 1 \mathrm{H}), 5.64-5.56(\mathrm{~m}, 2 \mathrm{H}), 5.49$ $(\mathrm{t}, J=10.5 \mathrm{~Hz}, 1 \mathrm{H}), 5.42(\mathrm{t}, J=10.5 \mathrm{~Hz}, 1 \mathrm{H}), 5.28-5.20(\mathrm{~m}, 2 \mathrm{H}), 5.13(\mathrm{~d}, J=10.1 \mathrm{~Hz}, 1 \mathrm{H}), 4.69$ $(\mathrm{d}, J=10.1 \mathrm{~Hz}, 1 \mathrm{H}), 4.57-4.51(\mathrm{~m}, 1 \mathrm{H}), 4.39(\mathrm{~d}, J=10.1,1 \mathrm{H}), 4.04-3.99(\mathrm{~m}, 1 \mathrm{H}), 3.78(\mathrm{~s}, 3 \mathrm{H})$, 3.71-3.67 (m, 1H), 3.59-3.52 (m, 2H), 3.41-3.35 (m, 2H), 3.12-3.01 (m, 1H), 2.82 (br s, 1H), 2.61-2.51 (m, 1H), 2.45-2.36 (m, 1H), 2.18-2.05 (m, 2H), 1.74-1.61 (m, 2H), 1.59-1.13 (m, 11H), 
1.10-1.04 (m, 12H), $1.01(\mathrm{~d}, J=6.9 \mathrm{~Hz}, 3 \mathrm{H}), 0.98(\mathrm{~d}, J=6.9 \mathrm{~Hz}, 3 \mathrm{H}), 0.97-0.89(\mathrm{~m}, 17 \mathrm{H}), 0.85$ (d, $J=6.4 \mathrm{~Hz}, 3 \mathrm{H}), 0.82(\mathrm{~d}, J=6.9 \mathrm{~Hz}, 3 \mathrm{H}), 0.77$ (s, 9H), 0.44 (s, 6H), 0.01 (s, 6H); MS (ESI) $m / z 1434.1[\mathrm{M}+\mathrm{Na}]^{+}$; HRMS (ESI) calcd for $\mathrm{C}_{80} \mathrm{H}_{121} \mathrm{O}_{7} \mathrm{~F}_{7} \mathrm{Si}_{3} \mathrm{Na}[\mathrm{M}+\mathrm{Na}]^{+}$1433.8206, found 1433.8243 .

20b $\left(\mathrm{C}_{4} \mathrm{~F}_{9}\right):{ }^{1} \mathrm{H}$ NMR $\left(500 \mathrm{MHz}, \mathrm{CDCl}_{3}\right) \delta$ 7.47-7.42 (m, 5H), 7.31-7.19 (m, 12H), $6.84(\mathrm{~d}, J=$ $8.7 \mathrm{~Hz}, 2 \mathrm{H}), 6.67$ (dt, $J=17.0,10.5 \mathrm{~Hz}, 1 \mathrm{H}), 6.06$ (t, $J=10.5 \mathrm{~Hz}, 1 \mathrm{H}), 5.76$ (dd, $J=15.6,8.3 \mathrm{~Hz}$, 1H), $5.64(\mathrm{dt}, J=15.6,5.5 \mathrm{~Hz}, 1 \mathrm{H}), 5.59$ (t, $J=10.5 \mathrm{~Hz}, 1 \mathrm{H}), 5.31(\mathrm{t}, J=10.5 \mathrm{~Hz}, 1 \mathrm{H}), 5.23(\mathrm{~d}$, $J=15.6 \mathrm{~Hz}, 1 \mathrm{H}), 5.18-5.11(\mathrm{~m}, 2 \mathrm{H}), 4.69(\mathrm{~d}, J=10.1 \mathrm{~Hz}, 1 \mathrm{H}), 4.39(\mathrm{~d}, J=10.1 \mathrm{~Hz}, 1 \mathrm{H})$, 4.39-4.34 (m, 1H), 3.78 (s, 3H), 3.69-3.65 (m, 1H), 3.55-3.49 (m, 2H), 3.39 (dd, J=6.9, 4.1 Hz, 1H), 3.16-3.13 (m, 1H), 3.10-3.01 (m, 1H), $2.82(\mathrm{br} \mathrm{s}, 1 \mathrm{H}), 2.47-2.40(\mathrm{~m}, 1 \mathrm{H}), 2.32-2.24(\mathrm{~m}, 1 \mathrm{H})$, 2.18-2.06 (m, 2H), 1.73-1.65 (m, 1H), 1.61-1.16 (m, 12H), 1.07-0.99 (m, 18H), $0.94(\mathrm{~d}, J=6.9$ $\mathrm{Hz}, 3 \mathrm{H}), 0.87-0.82(\mathrm{~m}, 20 \mathrm{H}), 0.75$ (d, $J=6.4 \mathrm{~Hz}, 3 \mathrm{H}), 0.55$ (d, $J=6.9 \mathrm{~Hz}, 3 \mathrm{H}), 0.01(\mathrm{~s}, 3 \mathrm{H})$, $0.00(\mathrm{~s}, 3 \mathrm{H}),-0.01$ (s, 3H), $-0.02(\mathrm{~s}, 3 \mathrm{H})$; MS (ESI) $\mathrm{m} / z 1483.1[\mathrm{M}+\mathrm{Na}]^{+}$; HRMS (ESI) calcd for $\mathrm{C}_{81} \mathrm{H}_{121} \mathrm{O}_{7} \mathrm{~F}_{9} \mathrm{Si}_{3} \mathrm{Na}[\mathrm{M}+\mathrm{Na}]^{+}$1483.8174, found 1483.8114 .

20c $\left(\mathrm{C}_{6} \mathrm{~F}_{13}\right):{ }^{1} \mathrm{H}$ NMR $\left(500 \mathrm{MHz}, \mathrm{CDCl}_{3}\right) \delta$ 7.46-7.42 (m, 5H), 7.31-7.18 (m, 12H), $6.84(\mathrm{~d}, J=$ $8.7 \mathrm{~Hz}, 2 \mathrm{H}), 6.67$ (dt, $J=16.5,11.0 \mathrm{~Hz}, 1 \mathrm{H}), 6.06$ (t, $J=11.0 \mathrm{~Hz}, 1 \mathrm{H}), 5.73$ (dd, $J=16.0,6.0 \mathrm{~Hz}$, 1H), 5.57 (dt, $J=15.6,5.5 \mathrm{~Hz}, 1 \mathrm{H}), 5.50$ (t, $J=10.5 \mathrm{~Hz}, 1 \mathrm{H}), 5.38$ (t, $J=10.5 \mathrm{~Hz}, 1 \mathrm{H})$, 5.27-5.19 (m, 2H), $5.13(\mathrm{~d}, J=10.1 \mathrm{~Hz}, 1 \mathrm{H}), 4.69(\mathrm{~d}, J=10.1 \mathrm{~Hz}, 1 \mathrm{H}), 4.57-4.51(\mathrm{~m}, 1 \mathrm{H}), 4.39$ (d, $J=10.1 \mathrm{~Hz}, 1 \mathrm{H}), 4.01-3.97$ (m, 1H), 3.78 (s, 3H), 3.69-3.64 (m, 1H), 3.54 (d, $J=5.5 \mathrm{~Hz}, 2 \mathrm{H})$, 3.41-3.37 (m, 1H), 3.35-3.31 (m, 1H), 3.10-3.02 (m, 1H), 2.77 (br s, 1H), 2.55-2.46 (m, 1H), 2.45-2.39 (m, 1H), 2.19-2.03 (m, 2H), 1.72-1.65 (m, 1H), 1.64-1.13 (m, 12H), 1.07-1.03 (m, 12H), 1.02 (d, $J=6.9 \mathrm{~Hz}, 3 \mathrm{H}), 0.97$ (d, $J=6.9 \mathrm{~Hz}, 3 \mathrm{H}), 0.93$ (d, $J=7.3 \mathrm{~Hz}, 6 \mathrm{H}), 0.91-0.88$ (m, 2H), 0.86 (s, 9H), 0.82 (s, 9H), $0.74(\mathrm{~d}, J=6.9 \mathrm{~Hz}, 3 \mathrm{H}), 0.72$ (d, $J=6.9 \mathrm{~Hz}, 3 \mathrm{H}), 0.04(\mathrm{~s}, 3 \mathrm{H})$, $0.03(\mathrm{~s}, 3 \mathrm{H}), 0.00(\mathrm{~s}, 3 \mathrm{H}),-0.01(\mathrm{~s}, 3 \mathrm{H})$; MS (ESI) $\mathrm{m} / z 1583.8[\mathrm{M}+\mathrm{Na}]^{+}$; HRMS (ESI) calcd for $\mathrm{C}_{83} \mathrm{H}_{121} \mathrm{O}_{7} \mathrm{~F}_{13} \mathrm{Si}_{3} \mathrm{Na}[\mathrm{M}+\mathrm{Na}]^{+}$1583.8110, found 1583.8086 .

20d $\left(\mathrm{C}_{8} \mathrm{~F}_{17}\right):{ }^{1} \mathrm{H}$ NMR $\left(500 \mathrm{MHz}, \mathrm{CDCl}_{3}\right) \delta$ 7.47-7.42 (m, 5H), 7.31-7.19 (m, 12H), $6.83(\mathrm{~d}, J=$ $8.7 \mathrm{~Hz}, 2 \mathrm{H}), 6.67$ (dt, $J=16.5,11.0 \mathrm{~Hz}, 1 \mathrm{H}), 6.06$ (t, $J=11.0 \mathrm{~Hz}, 1 \mathrm{H}), 5.82(\mathrm{dd}, J=15.6,7.3 \mathrm{~Hz}$, 
1H), $5.58(\mathrm{dt}, J=15.6,4.6 \mathrm{~Hz}, 1 \mathrm{H}), 5.50(\mathrm{t}, J=10.5 \mathrm{~Hz}, 1 \mathrm{H}), 5.29-5.20(\mathrm{~m}, 3 \mathrm{H}), 5.13(\mathrm{~d}, J=$ $10.5 \mathrm{~Hz}, 1 \mathrm{H}), 4.69$ (d, $J=10.1 \mathrm{~Hz}, 1 \mathrm{H}), 4.43-4.37$ (m, 2H), 4.18-4.12 (m, 1H), $3.78(\mathrm{~s}, 3 \mathrm{H})$, 3.72-3.66 (m, 1H), 3.58-3.49 (m, 2H), 3.42-3.34 (m, 2H), 3.10-3.03 (m, 1H), 2.81 (br s, 1H), 2.56-2.47 (m, 1H), 2.43-2.36 (m, 1H), 2.13-2.00 (m, 2H), 1.74-1.19 (m, 13H), 1.05-0.92 (m, 24H), 0.91-0.75 (m, 26H), 0.06 (s, 3H), 0.03 (s, 9H); MS (ESI) $m / z 11683.8[\mathrm{M}+\mathrm{Na}]^{+}$; HRMS (ESI) calcd for $\mathrm{C}_{85} \mathrm{H}_{121} \mathrm{O}_{7} \mathrm{~F}_{17} \mathrm{Si}_{3} \mathrm{Na}[\mathrm{M}+\mathrm{Na}]^{+}$1683.8046, found 1683.8005 .

A sample of $\propto$-alcohols M-20 $\left(\mathrm{R}_{\mathrm{f}}=0.28, \mathrm{Et}_{2} \mathrm{O} /\right.$ hexanes $\left.88: 12\right)$ was demixed by semipreparative HPLC (isocratic elution with acetonitrile for $100 \mathrm{~min}$ ) to give four fluorous $\alpha$-alcohols: 20a $\left(\mathrm{C}_{3} \mathrm{~F}_{7}\right), 20 \mathbf{b}\left(\mathrm{C}_{4} \mathrm{~F}_{9}\right), \mathbf{2 0 c}\left(\mathrm{C}_{6} \mathrm{~F}_{13}\right), 20 \mathrm{~d}\left(\mathrm{C}_{8} \mathrm{~F}_{17}\right)$.

A sample of $\alpha$-alcohols M-20a-d $\left(\mathrm{R}_{\mathrm{f}}=0.25, \mathrm{Et}_{2} \mathrm{O} /\right.$ hexanes 88:12) was demixed by semipreparative HPLC (gradient elution from 95:5 acetonitrile/ $\mathrm{H}_{2} \mathrm{O}$ to $100 \%$ acetonitrile in 20 $\min$ and isocratic acetonitrile for another $100 \mathrm{~min})$ to give four fluorous $\alpha$-alcohols: $\mathbf{2 0 a}\left(\mathrm{C}_{3} \mathrm{~F}_{7}\right)$, $20 \mathbf{b}\left(\mathrm{C}_{4} \mathrm{~F}_{9}\right), 20 \mathbf{c}\left(\mathrm{C}_{6} \mathrm{~F}_{13}\right), 20 d\left(\mathrm{C}_{8} \mathrm{~F}_{17}\right)$.

20a $\left(\mathrm{C}_{3} \mathrm{~F}_{7}, \alpha\right.$-alcohol): ${ }^{1} \mathrm{H}$ NMR $\left(500 \mathrm{MHz}, \mathrm{CDCl}_{3}\right) \delta$ 7.49-7.43 (m, 5H), 7.33-7.20 (m, 12H), $6.84(\mathrm{~d}, J=8.3 \mathrm{~Hz}, 2 \mathrm{H}), 6.67$ (dt, $J=16.5,11.0 \mathrm{~Hz}, 1 \mathrm{H}), 6.03$ (t, $J=11.0 \mathrm{~Hz}, 1 \mathrm{H}), 5.64-5.58$ (m, 2H), $5.55(\mathrm{t}, J=11.0 \mathrm{~Hz}, 1 \mathrm{H}), 5.42(\mathrm{t}, J=11.0 \mathrm{~Hz}, 1 \mathrm{H}), 5.30-5.18(\mathrm{~m}, 2 \mathrm{H}), 5.11(\mathrm{~d}, J=10.1 \mathrm{~Hz}$, 1H), 4.61-4.47 (m, 3H), 4.05-3.99 (m, 1H), $3.78(\mathrm{~s}, 3 \mathrm{H}), 3.59-3.51(\mathrm{~m}, 4 \mathrm{H}), 3.41-3.36(\mathrm{~m}, 1 \mathrm{H})$, 3.05-2.96 (m, 1H), 2.66-2.53 (m, 2H), 2.45-2.37 (m, 1H), 2.20-2.05 (m, 2H), 1.84-1.75 (m, 1H), 1.74-1.64 (m, 1H), 1.58-1.04 (m, 23H), 1.04-0.76 (m, 38H), 0.07-0.02 (m, 6H), 0.00 (s, 6H); MS (ESI) $m / z$ 1434.2 [M + Na] $]^{+}$; HRMS (ESI) calcd for $\mathrm{C}_{80} \mathrm{H}_{121} \mathrm{O}_{7} \mathrm{~F}_{7} \mathrm{Si}_{3} \mathrm{Na}[\mathrm{M}+\mathrm{Na}]^{+}$1433.8206, found 1433.8228 .

20b $\left(\mathrm{C}_{4} \mathrm{~F}_{9}, \alpha\right.$-alcohol): ${ }^{1} \mathrm{H}$ NMR (500 MHz, $\left.\mathrm{CDCl}_{3}\right) \delta$ 7.47-7.42 (m, 5H), 7.31-7.19 (m, 12H), $6.84(\mathrm{~d}, J=8.7 \mathrm{~Hz}, 2 \mathrm{H}), 6.67(\mathrm{dt}, J=17.0,10.5 \mathrm{~Hz}, 1 \mathrm{H}), 6.03(\mathrm{t}, J=11.0 \mathrm{~Hz}, 1 \mathrm{H}), 5.77(\mathrm{dd}, J=$ 15.6, 7.8 Hz, 1H), $5.64(\mathrm{dt}, J=15.6,5.5 \mathrm{~Hz}, 1 \mathrm{H}), 5.55(\mathrm{t}, J=10.5 \mathrm{~Hz}, 1 \mathrm{H}), 5.30(\mathrm{t}, J=10.5 \mathrm{~Hz}$, 1H), 5.23-5.14 (m, 2H), $5.11(\mathrm{~d}, J=10.1 \mathrm{~Hz}, 1 \mathrm{H}), 4.57(\mathrm{~d}, J=10.5 \mathrm{~Hz}, 1 \mathrm{H}), 4.49(\mathrm{~d}, J=10.5 \mathrm{~Hz}$, 1H), 4.40-4.34 (m, 1H), 4.06-4.01 (m, 1H), $3.78(\mathrm{~s}, 3 \mathrm{H}), 3.53-3.57(\mathrm{~m}, 4 \mathrm{H}), 3.18-3.15(\mathrm{~m}, 1 \mathrm{H})$, 3.03-2.95 (m, 1H), 2.58 (br s, 1H), 2.47-2.40 (m, 1H), 2.33-2.25 (m, 1H), 2.18-2.05 (m, 2H), 
$1.81-1.74(\mathrm{~m}, 1 \mathrm{H}), 1.63-1.18(\mathrm{~m}, 12 \mathrm{H}), 1.13(\mathrm{~d}, J=6.9 \mathrm{~Hz}, 3 \mathrm{H}), 1.08-1.00(\mathrm{~m}, 15 \mathrm{H}), 0.98(\mathrm{~d}, J=$ $6.9 \mathrm{~Hz}, 3 \mathrm{H}), 0.93$ (d, $J=6.9 \mathrm{~Hz}, 3 \mathrm{H}), 0.90-0.81(\mathrm{~m}, 20 \mathrm{H}), 0.76$ (d, $J=6.4 \mathrm{~Hz}, 3 \mathrm{H}), 0.57$ (d, $J=$ $6.4 \mathrm{~Hz}, 3 \mathrm{H}), 0.02-0.02(\mathrm{~m}, 12 \mathrm{H})$; MS (ESI) $m / z 1484.2[\mathrm{M}+\mathrm{Na}]^{+}$; HRMS (ESI) calcd for $\mathrm{C}_{81} \mathrm{H}_{121} \mathrm{O}_{7} \mathrm{~F}_{9} \mathrm{Si}_{3} \mathrm{Na}[\mathrm{M}+\mathrm{Na}]^{+}$1483.8174, found 1483.8192 .

20c $\left(\mathrm{C}_{6} \mathrm{~F}_{13}, \alpha\right.$-alcohol): ${ }^{1} \mathrm{H}$ NMR (500 MHz, $\left.\mathrm{CDCl}_{3}\right) \delta$ 7.46-7.42 (m, 5H), 7.30-7.18 (m, $\left.12 \mathrm{H}\right)$, $6.84(\mathrm{~d}, J=8.3 \mathrm{~Hz}, 2 \mathrm{H}), 6.67(\mathrm{dt}, J=17.0,10.5 \mathrm{~Hz}, 1 \mathrm{H}), 6.03(\mathrm{t}, J=10.5 \mathrm{~Hz}, 1 \mathrm{H}), 5.74(\mathrm{dd}, J=$ 15.6, $6.0 \mathrm{~Hz}, 1 \mathrm{H}), 5.60-5.52(\mathrm{~m}, 2 \mathrm{H}), 5.38(\mathrm{t}, J=10.5 \mathrm{~Hz}, 1 \mathrm{H}), 5.27-5.18(\mathrm{~m}, 2 \mathrm{H}), 5.11(\mathrm{~d}, J=$ 10.1 Hz, 1H), 4.59-4.47 (m, 3H), 4.01-3.97 (m, 1H), 3.78 (s, 3H), 3.58-3.49 (m, 4H), 3.36-3.32 (m, 1H), 3.04-2.96 (m, 1H), $2.58($ br s, 1H), 2.54-2.47 (m, 1H), 2.46-2.39 (m, 1H), 2.16-2.03 (m, $2 \mathrm{H}), 1.81-1.72(\mathrm{~m}, 1 \mathrm{H}), 1.67-1.59(\mathrm{~m}, 1 \mathrm{H}), 1.56-1.08(\mathrm{~m}, 11 \mathrm{H}), 1.08-1.01(\mathrm{~m}, 12 \mathrm{H}), 1.00-0.96$ (m, 6H), 0.94 (d, $J=6.9 \mathrm{~Hz}, 3 \mathrm{H}), 0.92$ (d, $J=6.9 \mathrm{~Hz}, 3 \mathrm{H}), 0.91-0.87$ (m, 2H), 0.86 (s, 9H), 0.82 (s, 9H), $0.76(\mathrm{~d}, J=6.9 \mathrm{~Hz}, 3 \mathrm{H}), 0.74(\mathrm{~d}, J=6.9 \mathrm{~Hz}, 3 \mathrm{H}), 0.04$ (s, 3H), $0.03(\mathrm{~s}, 3 \mathrm{H}), 0.00(\mathrm{~s}, 3 \mathrm{H})$, -0.01 (s, 3H); MS (ESI) $m / z 1583.8[\mathrm{M}+\mathrm{Na}]^{+}$; HRMS (ESI) calcd for $\mathrm{C}_{83} \mathrm{H}_{121} \mathrm{O}_{7} \mathrm{~F}_{13} \mathrm{Si}_{3} \mathrm{Na}[\mathrm{M}+$ $\mathrm{Na}]^{+} 1583.8110$, found 1583.8163 .

20d $\left(\mathrm{C}_{8} \mathrm{~F}_{17}, \alpha\right.$-alcohol): ${ }^{1} \mathrm{H}$ NMR (500 MHz, $\left.\mathrm{CDCl}_{3}\right) \delta$ 7.46-7.42 (m, 5H), 7.30-7.19 (m, 12H), $6.84(\mathrm{~d}, J=8.7 \mathrm{~Hz}, 2 \mathrm{H}), 6.67(\mathrm{dt}, J=17.0,10.5 \mathrm{~Hz}, 1 \mathrm{H}), 6.03(\mathrm{t}, J=11.0 \mathrm{~Hz}, 1 \mathrm{H}), 5.82(\mathrm{dd}, J=$ 15.6, 7.3 Hz, 1H), 5.61-5.52 (m, 2H), 5.28-5.18 (m, 3H), $5.11(\mathrm{~d}, J=10.5 \mathrm{~Hz}, 1 \mathrm{H}), 4.57$ (d, $J=$ $10.5 \mathrm{~Hz}, 1 \mathrm{H}), 4.50(\mathrm{~d}, J=10.5 \mathrm{~Hz}, 1 \mathrm{H}), 4.43-4.37(\mathrm{~m}, 1 \mathrm{H}), 4.18-4.13(\mathrm{~m}, 1 \mathrm{H}), 3.78(\mathrm{~s}, 3 \mathrm{H})$, 3.59-3.50 (m, 4H), 3.38-3.35 (m, 1H), 3.04-2.96 (m, 1H), 2.66 (br s, 1H), 2.56-2.48 (m, 1H), 2.43-2.35 (m, 1H), 2.13-2.00 (m, 2H), 1.83-1.09 (m, 13H), 1.06-0.91 (m, 24H), 0.91-0.75 (m, 26H), 0.07-0.02 (m, 12H); MS (ESI) $\mathrm{m} / z$ 1684.3 [M + Na] $]^{+}$; HRMS (ESI) calcd for $\mathrm{C}_{85} \mathrm{H}_{121} \mathrm{O}_{7} \mathrm{~F}_{17} \mathrm{Si}{ }_{3} \mathrm{Na}[\mathrm{M}+\mathrm{Na}]^{+}$1683.8046, found 1683.8103 . 


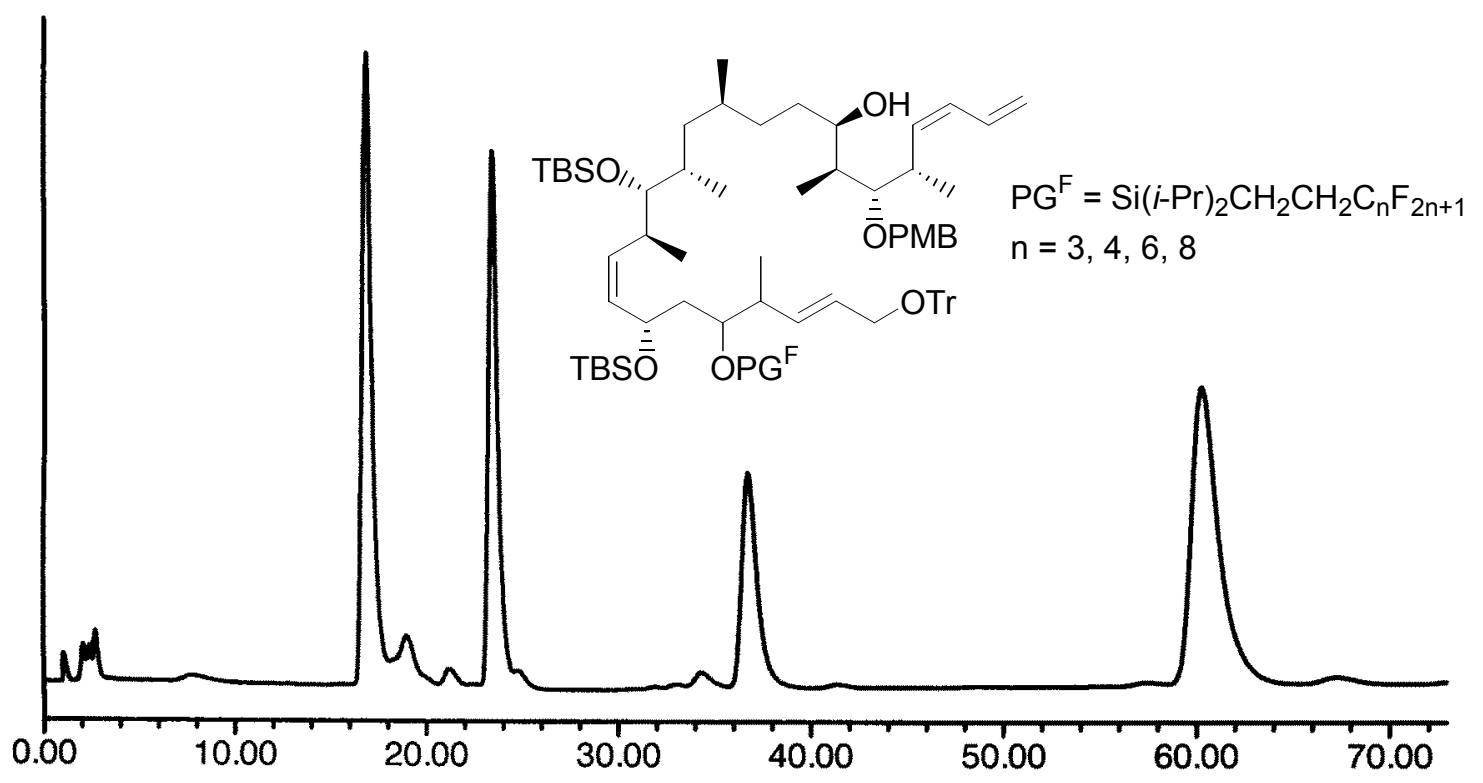

HPLC of $\alpha$-alcohols M-20a-d $\left(\mathrm{R}_{\mathrm{f}}=0.25, \mathrm{Et}_{2} \mathrm{O} /\right.$ hexanes 88:12): FluoroFlash PF-C8 (Fluorous Technologies, Inc.) $4.6 \times 150 \mathrm{~mm}, 100 \mathrm{~A}, 5 \mu \mathrm{m}$, UV detection at $230 \mathrm{~nm}$, gradient elution from 90:10 acetonitrile/ $\mathrm{H}_{2} \mathrm{O}$ to $100 \%$ acetonitrile in $20 \mathrm{~min}$ and isocratic acetonitrile for another 60 min. 20a $\left(\mathrm{C}_{3} \mathrm{~F}_{7}\right): 16.8 \mathrm{~min}, 20 \mathbf{b}\left(\mathrm{C}_{4} \mathrm{~F}_{9}\right): 23.4 \mathrm{~min}, \mathbf{2 0 c}\left(\mathrm{C}_{6} \mathrm{~F}_{13}\right): 36.7 \mathrm{~min}, \mathbf{2 0 d}\left(\mathrm{C}_{8} \mathrm{~F}_{17}\right): 60.3 \mathrm{~min}$. $\mathbf{2 0 a} / \mathbf{2 0 b} / \mathbf{2 0 c} / \mathbf{2 0 d}=2.0: 1.6: 1.0: 2.4$.

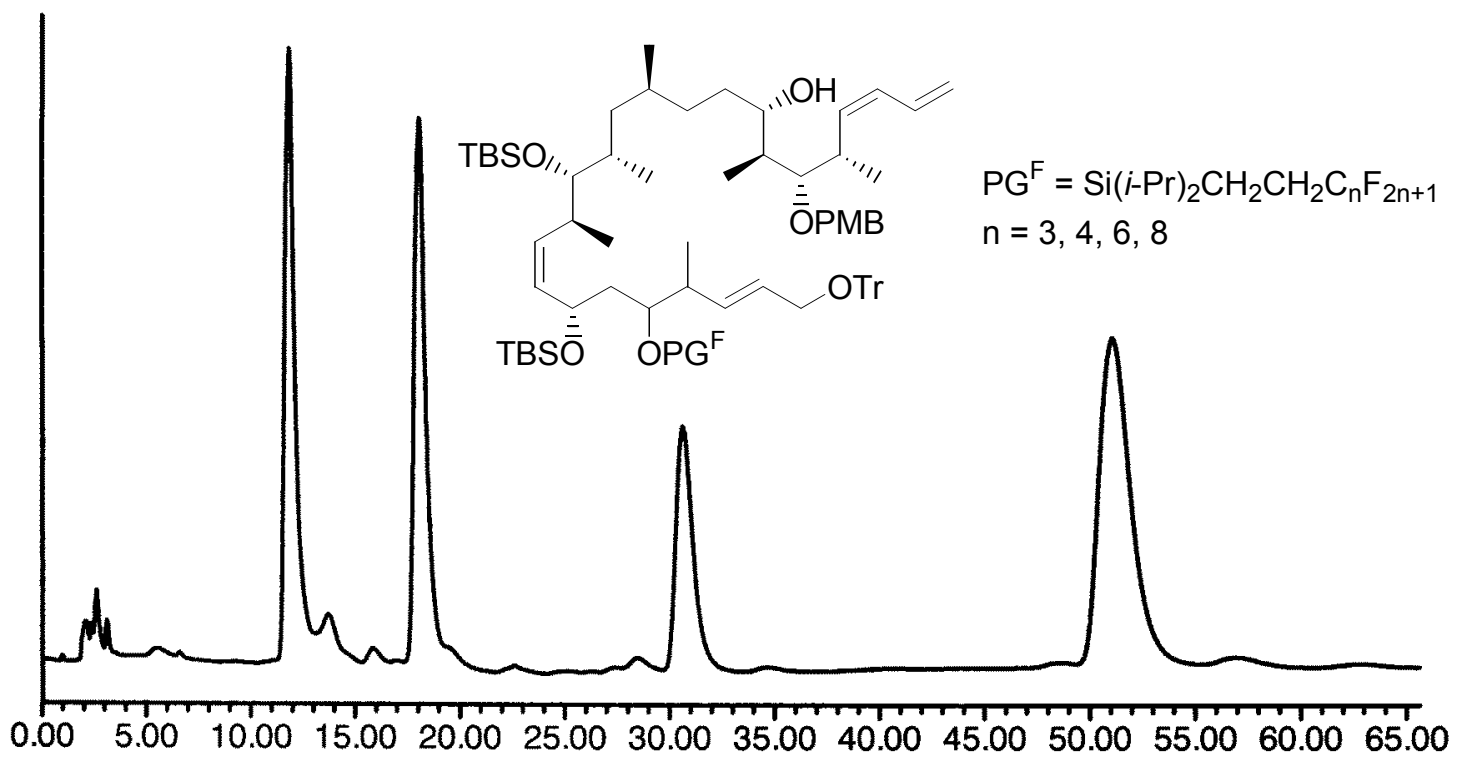

HPLC of $\beta$-alcohols M-20 $\left(\mathrm{R}_{\mathrm{f}}=0.28, \mathrm{Et}_{2} \mathrm{O} /\right.$ hexanes 88:12): FluoroFlash PF-C8 (Fluorous Technologies, Inc.) 4.6 x $150 \mathrm{~mm}, 100 \mathrm{~A}, 5 \mu \mathrm{m}$, UV detection at $220 \mathrm{~nm}$, gradient elution from 90:10 acetonitrile/ $\mathrm{H}_{2} \mathrm{O}$ to $100 \%$ acetonitrile in $20 \mathrm{~min}$ and isocratic acetonitrile for another 45 
min. 20a $\left(\mathrm{C}_{3} \mathrm{~F}_{7}\right)$ : $11.8 \mathrm{~min}, 20 \mathbf{b}\left(\mathrm{C}_{4} \mathrm{~F}_{9}\right): 18.1 \mathrm{~min}, \mathbf{2 0 c}\left(\mathrm{C}_{6} \mathrm{~F}_{13}\right): 30.7 \mathrm{~min}, \mathbf{2 0 d}\left(\mathrm{C}_{8} \mathrm{~F}_{17}\right): 51.1 \mathrm{~min}$. $\mathbf{2 0 a} / \mathbf{2 0 b} / \mathbf{2 0 c} / \mathbf{2 0 d}=1.6: 1.5: 1.0: 2.4$.

Four-component mixture of $(5 R, 8 S, 10 S, 11 R, 12 S, 13 Z, 15 S)-11,15$-Bis(tert-butyldimethylsilanyloxy)-22-perfluoroalkyl-19,19-diisopropyl-5-[(1R,2S,3S,4Z)-2-(4-methoxybenzyl-oxy)1,3-dimethylhepta-4,6-dienyl]-2,2,3,3,8,10,12-heptamethyl-17-[(2E)-1-methyl-3-trityloxypro p-2-enyl]-4,18-dioxa-3,19-disiladocos-13-ene:

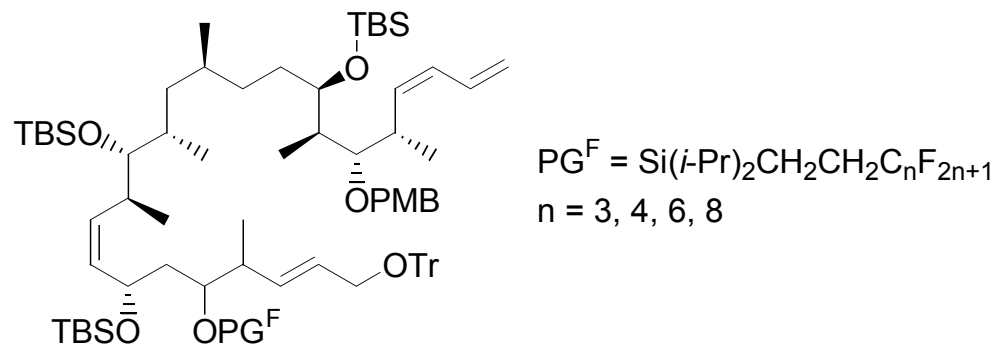

TBSOTf (432 mg, $1.63 \mathrm{mmol}$ ) was added to a solution of M-20a-d (833 mg, $545 \mu \mathrm{mol})$ and triethylamine $(460 \mu \mathrm{l}, 3.30 \mathrm{mmol})$ in $\mathrm{CH}_{2} \mathrm{Cl}_{2}(30 \mathrm{~mL})$ at $0{ }^{\circ} \mathrm{C}$. The reaction mixture was stirred for $1 \mathrm{~h}$ at $0{ }^{\circ} \mathrm{C}$ and then quenched with a saturated aqueous $\mathrm{NaHCO}_{3}$ solution and extracted with $\mathrm{CH}_{2} \mathrm{Cl}_{2}$. The combined organic extracts were washed with brine, dried over $\mathrm{MgSO}_{4}$ and concentrated under reduced pressure. The residue was purified by flash chromatography (AcOEt/hexanes 5:95) to give the silyl ether (895 mg, quant.).

Four-component mixture of $(2 E, 7 S, 8 Z, 10 S, 11 R, 12 S, 14 S, 17 R, 18 R, 19 S, 20 S, 21 Z)$ 7,11,17-tris(tert-butyldimethylsilyloxy)-5-diisopropylperfluoroalkylethylsilyloxy-19-(4-met hoxybenzyloxy)-4,10,12,14,18,20-hexamethyltetracosa-2,8,21,23-tetraen-1-ol: 


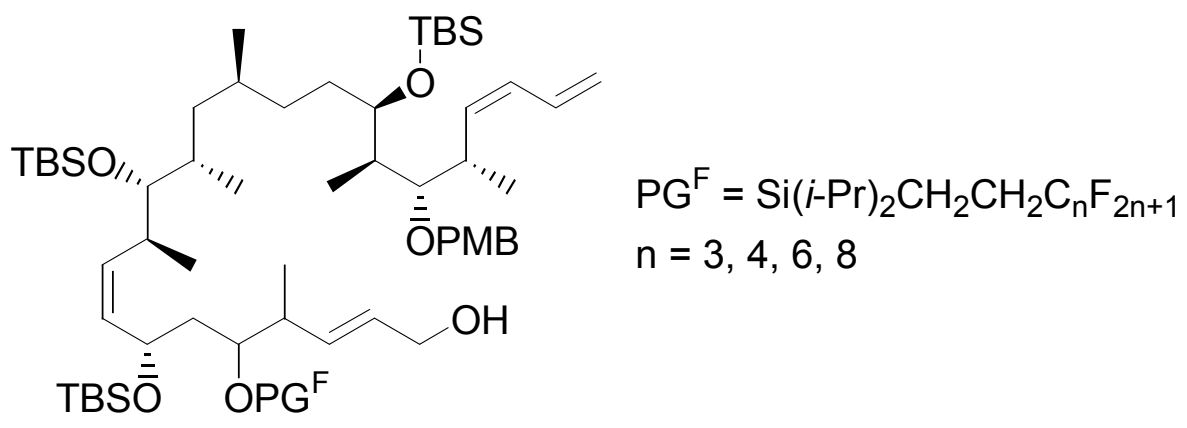

A solution of $\mathrm{ZnBr}_{2}(606 \mathrm{mg}, 2.69 \mathrm{mmol})$ in a mixture of $\mathrm{CH}_{2} \mathrm{Cl}_{2}$ and $\mathrm{MeOH}\left(\mathrm{CH}_{2} \mathrm{Cl}_{2} / \mathrm{MeOH}\right.$ $6: 1,6 \mathrm{~mL})$ was added to a solution of the above silyl ether $(885 \mathrm{mg}, 0.538 \mathrm{mmol})$ in a mixture of $\mathrm{CH}_{2} \mathrm{Cl}_{2}$ and $\mathrm{MeOH}\left(\mathrm{CH}_{2} \mathrm{Cl}_{2} / \mathrm{MeOH} 6: 1,30 \mathrm{~mL}\right)$ at $0{ }^{\circ} \mathrm{C}$ over $30 \mathrm{~min}$. After stirring for $1.5 \mathrm{~h}$ at $0{ }^{\circ} \mathrm{C}$, the reaction mixture was warmed to room temperature and stirring continued for $2.5 \mathrm{~h}$. More $\mathrm{ZnBr}_{2}$ (606 mg, $\left.2.69 \mathrm{mmol}\right)$ was added and stirring continued for $17.5 \mathrm{~h}$. Then, after a third addition of $\mathrm{ZnBr}_{2}$ (364 mg, $1.62 \mathrm{mmol}$ ) and stirring for $7.5 \mathrm{~h}$, the reaction mixture was quenched with a saturated aqueous $\mathrm{NaHCO}_{3}$ solution and extracted with $\mathrm{CH}_{2} \mathrm{Cl}_{2}$. The combined organic extracts were washed with brine, dried over $\mathrm{MgSO}_{4}$ and concentrated under reduced pressure. The residue was purified by flash chromatography (AcOEt/hexanes 5:95 to 10:90) to give the alcohols (698 mg, 93\%).

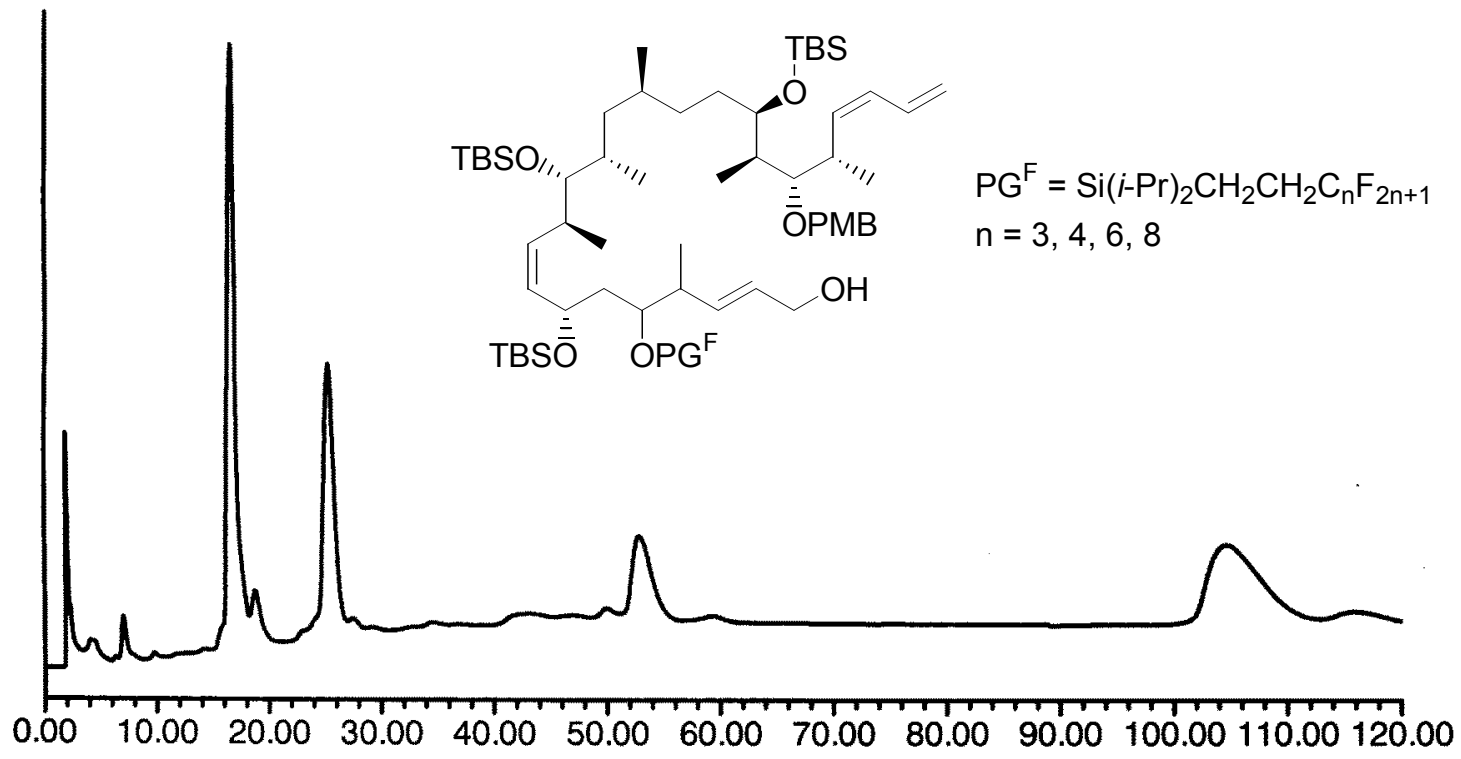


HPLC: FluoroFlash PF-C8 (Fluorous Technologies, Inc.) 4.6 x 150 mm, 100 A, 5 um, UV detection at $220 \mathrm{~nm}$, gradient elution from 100\% acetonitrile to 95:5 acetonitrile/THF in $40 \mathrm{~min}$ and isocratic 95:5 acetonitrile/THF for another $80 \mathrm{~min}$. a $\left(\mathrm{C}_{3} \mathrm{~F}_{7}\right): 16.5 \mathrm{~min}, \mathbf{b}\left(\mathrm{C}_{4} \mathrm{~F}_{9}\right): 25.2 \mathrm{~min}, \mathbf{c}$ $\left(\mathrm{C}_{6} \mathrm{~F}_{13}\right): 52.8 \mathrm{~min}, \mathbf{d}\left(\mathrm{C}_{8} \mathrm{~F}_{17}\right): 104.6 \mathrm{~min} . \mathbf{a} / \mathbf{b} / \mathbf{c} / \mathbf{d}=3.1: 1.8: 1.0: 2.1$.

Four-component mixture of methyl $(2 Z, 4 E, 9 S, 10 Z, 12 S, 13 R, 14 S, 16 S, 19 R, 20 R, 21 S, 22 S$,

23Z)-9,13,19-tris(tert-butyl-dimethylsilyloxy)-7-diisopropylperfluoroalkylethylsilyloxy-21-(4

-methoxybenzyloxy)-6,12,14,16,20,22-hexamethylhexacosa-2,4,10,23,25-pentaenoate

M-21a-d:

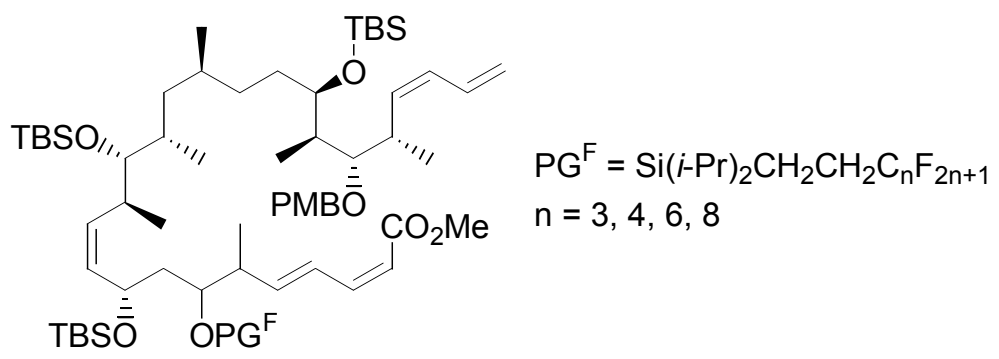

Dess-Martin periodinane $(219 \mathrm{mg}, 516 \mu \mathrm{mol})$ was added to a solution of the above alcohol (482 $\mathrm{mg}, 344 \mu \mathrm{mol})$ in $\mathrm{CH}_{2} \mathrm{Cl}_{2}(16 \mathrm{~mL})$ at $0{ }^{\circ} \mathrm{C}$. After stirring for $1 \mathrm{~h}$ at room temperature, the reaction mixture was quenched with saturated aqueous $\mathrm{NaHCO}_{3}$ and $1 \mathrm{M}$ aqueous $\mathrm{Na}_{2} \mathrm{~S}_{2} \mathrm{O}_{3}$, and extracted with ether. The combined organic extracts were washed with brine, dried over $\mathrm{MgSO}_{4}$ and concentrated under reduced pressure. The residue was purified by flash chromatography (short package of silica gel, AcOEt/hexanes 10:90) to give a mixture of the corresponding aldehydes, which was used for the next reaction without further purification. Potassium bis(trimethylsilyl)amide $(1.03 \mathrm{~mL}, 515 \mu \mathrm{mol}, 0.5 \mathrm{M}$ solution in toluene) was added dropwise to a solution of bis(2,2,2-trifluoroethyl)(methoxycarbonylmethyl) phosphonate ${ }^{16}$ (166 mg, 522 $\mu \mathrm{mol})$ and 18-crown-6 (455 mg, $1.72 \mathrm{mmol})$ in THF $(7.5 \mathrm{~mL})$ at $-78{ }^{\circ} \mathrm{C}$. After stirring for $0.5 \mathrm{~h}$ at $-78{ }^{\circ} \mathrm{C}$, a solution of the mixture aldehydes in THF $(2.5 \mathrm{~mL})$ was added and the reaction

${ }^{16}$ Still, W. C.; Gennari, C. Tetrahedron Lett. 1983, 24, 4405-4408. 
mixture was stirred for $5 \mathrm{~h}$ at $-78^{\circ} \mathrm{C}$. Then, the reaction mixture was gradually warmed to room temperature and stirring continued for $13 \mathrm{~h}$. The reaction mixture was quenched with a saturated aqueous $\mathrm{NH}_{4} \mathrm{Cl}$ solution and extracted with ether. The combined organic extracts were washed with brine, dried over $\mathrm{MgSO}_{4}$ and concentrated under reduced pressure. The residue was purified by flash chromatography (AcOEt/hexanes 2:98) to give M-21a-d (393 mg, 80\% over 2 steps). A sample was demixed by semipreparative HPLC (gradient elution from 100\% acetonitrile to acetonitrile/THF $95: 5$ in $40 \mathrm{~min}$ to acetonitrile/THF $90: 10$ in $5 \mathrm{~min}$ and isocratic acetonitrile/THF 90:10 for additional $120 \mathrm{~min})$ to give $\mathbf{2 1 a}\left(\mathrm{C}_{3} \mathrm{~F}_{7}\right), \mathbf{2 1} \mathbf{b}\left(\mathrm{C}_{4} \mathrm{~F}_{9}\right), \mathbf{2 1} \mathbf{c}\left(\mathrm{C}_{6} \mathrm{~F}_{13}\right)$, and 21d $\left(\mathrm{C}_{8} \mathrm{~F}_{17}\right)$.

21a $\left(\mathrm{C}_{3} \mathrm{~F}_{7}\right):{ }^{1} \mathrm{H}$ NMR $\left(300 \mathrm{MHz}, \mathrm{CDCl}_{3}\right) \delta 7.38(\mathrm{dd}, J=15.3,11.2 \mathrm{~Hz}, 1 \mathrm{H}), 7.31-7.21(\mathrm{~m}, 2 \mathrm{H})$, $6.86(\mathrm{~d}, J=8.7 \mathrm{~Hz}, 2 \mathrm{H}), 6.65-6.47(\mathrm{~m}, 1 \mathrm{H}), 6.53(\mathrm{t}, J=11.4 \mathrm{~Hz}, 1 \mathrm{H}), 6.03-5.90(\mathrm{~m}, 2 \mathrm{H}), 5.60(\mathrm{~d}$, $J=11.4 \mathrm{~Hz}, 1 \mathrm{H}), 5.57(\mathrm{t}, J=10.8 \mathrm{~Hz}, 1 \mathrm{H}), 5.39(\mathrm{t}, J=10.2 \mathrm{~Hz}, 1 \mathrm{H}), 5.28-5.04(\mathrm{~m}, 3 \mathrm{H})$, 4.63-4.45 (m, 3H), $4.06(\mathrm{~m}, 1 \mathrm{H}), 3.80(\mathrm{~s}, 3 \mathrm{H}), 3.72(\mathrm{~s}, 3 \mathrm{H}), 3.60(\mathrm{~m}, 1 \mathrm{H}), 3.39-3.25(\mathrm{~m}, 2 \mathrm{H})$, $2.98(\mathrm{~m}, 1 \mathrm{H}), 2.55(\mathrm{~m}, 2 \mathrm{H}), 2.10(\mathrm{~m}, 2 \mathrm{H}), 1.70-0.70(\mathrm{~m}, 72 \mathrm{H}), 0.12-0.03(\mathrm{~m}, 18 \mathrm{H}) ;{ }^{19} \mathrm{~F}$ NMR $\left(282 \mathrm{MHz}, \mathrm{CDCl}_{3}\right) \delta-79.4(3 \mathrm{~F}),-116.2(2 \mathrm{~F}),-126.3(2 \mathrm{~F}) ; \mathrm{MS}(\mathrm{ESI}) \mathrm{m} / z 1359.7[\mathrm{M}+\mathrm{Na}]^{+}$.

21b $\left(\mathrm{C}_{4} \mathrm{~F}_{9}\right):{ }^{1} \mathrm{H}$ NMR (300 MHz, $\left.\mathrm{CDCl}_{3}\right) \delta 7.43(\mathrm{dd}, J=15.5,11.3 \mathrm{~Hz}, 1 \mathrm{H}), 7.35-7.23(\mathrm{~m}, 2 \mathrm{H})$, $6.86(\mathrm{~d}, J=8.7 \mathrm{~Hz}, 2 \mathrm{H}), 6.64-6.48(\mathrm{~m}, 1 \mathrm{H}), 6.52(\mathrm{t}, J=11.3 \mathrm{~Hz}, 1 \mathrm{H}), 6.25-6.14(\mathrm{~m}, 1 \mathrm{H}), 5.98(\mathrm{t}$, $J=11.0 \mathrm{~Hz}, 1 \mathrm{H}), 5.56(\mathrm{~d}, J=11.3 \mathrm{~Hz}, 1 \mathrm{H}), 5.62-5.52(\mathrm{~m}, 1 \mathrm{H}), 5.30(\mathrm{t}, J=10.3 \mathrm{~Hz}, 1 \mathrm{H})$, 5.23-5.05 (m, 3H), $4.51(\mathrm{~m}, 2 \mathrm{H}), 4.40(\mathrm{~m}, 1 \mathrm{H}), 4.13-4.03(\mathrm{~m}, 1 \mathrm{H}), 3.80(\mathrm{~s}, 3 \mathrm{H}), 3.71(\mathrm{~s}, 3 \mathrm{H})$, $3.59(\mathrm{~m}, 1 \mathrm{H}), 3.31(\mathrm{~m}, 1 \mathrm{H}), 3.22(\mathrm{~m}, 1 \mathrm{H}), 2.97(\mathrm{~m}, 1 \mathrm{H}), 2.60(\mathrm{~m}, 1 \mathrm{H}), 2.39-2.25(\mathrm{~m}, 1 \mathrm{H}), 2.12$ (m, 2H), 1.75-0.80 (m, 66H), $0.76(\mathrm{~d}, J=6.3 \mathrm{~Hz}, 3 \mathrm{H}), 0.68(\mathrm{~d}, J=6.8 \mathrm{~Hz}, 3 \mathrm{H}), 0.07(\mathrm{~s}, 3 \mathrm{H})$, $0.06(\mathrm{~s}, 6 \mathrm{H}), 0.03(\mathrm{~s}, 3 \mathrm{H}),-0.01(\mathrm{~s}, 6 \mathrm{H}) ;{ }^{19} \mathrm{~F}$ NMR $\left(282 \mathrm{MHz}, \mathrm{CDCl}_{3}\right) \quad-79.8(3 \mathrm{~F}),-115.5(2 \mathrm{~F})$, $-123.0(2 \mathrm{~F}),-124.9(2 \mathrm{~F})$.

21c $\left(\mathrm{C}_{6} \mathrm{~F}_{13}\right):{ }^{1} \mathrm{H}$ NMR $\left(300 \mathrm{MHz}, \mathrm{CDCl}_{3}\right) \delta 7.38(\mathrm{dd}, J=15.4,11.0 \mathrm{~Hz}, 1 \mathrm{H}), 7.30-7.23(\mathrm{~m}, 2 \mathrm{H})$, $6.86(\mathrm{~d}, J=8.7 \mathrm{~Hz}, 2 \mathrm{H}), 6.64-6.45(\mathrm{~m}, 1 \mathrm{H}), 6.50(\mathrm{t}, J=11.4 \mathrm{~Hz}, 1 \mathrm{H}), 6.21-6.11(\mathrm{~m}, 1 \mathrm{H}), 5.99(\mathrm{t}$, $J=11.0 \mathrm{~Hz}, 1 \mathrm{H}), 5.60(\mathrm{t}, J=9.9 \mathrm{~Hz}, 1 \mathrm{H}), 5.56(\mathrm{~d}, J=11.2 \mathrm{~Hz}, 1 \mathrm{H}), 5.39-5.04(\mathrm{~m}, 4 \mathrm{H})$, 4.61-4.45 (m, 3H), 4.10-4.01 (m, 1H), $3.80(\mathrm{~s}, 3 \mathrm{H}), 3.71(\mathrm{~s}, 3 \mathrm{H}), 3.60(\mathrm{~m}, 1 \mathrm{H}), 3.34-3.28(\mathrm{~m}, 2 \mathrm{H})$, 
$2.97(\mathrm{~m}, 1 \mathrm{H}), 2.64-2.43(\mathrm{~m}, 2 \mathrm{H}), 2.20-1.98(\mathrm{~m}, 2 \mathrm{H}), 1.78-0.73(\mathrm{~m}, 72 \mathrm{H}), 0.07-0.00(\mathrm{~s}, 18 \mathrm{H}) ;{ }^{19} \mathrm{~F}$ NMR (282 MHz, $\left.\mathrm{CDCl}_{3}\right) \delta-79.6(3 \mathrm{~F}),-115.3(2 \mathrm{~F}),-120.7(2 \mathrm{~F}),-121.7(2 \mathrm{~F}),-122.0(2 \mathrm{~F})$, $-124.9(2 \mathrm{~F})$.

21d $\left(\mathrm{C}_{8} \mathrm{~F}_{17}\right):{ }^{1} \mathrm{H}$ NMR $\left(300 \mathrm{MHz}, \mathrm{CDCl}_{3}\right) \delta 7.39(\mathrm{dd}, J=15.4,11.2 \mathrm{~Hz}, 1 \mathrm{H}), 7.33-7.23(\mathrm{~m}, 2 \mathrm{H})$, $6.86(\mathrm{~d}, J=8.7 \mathrm{~Hz}, 2 \mathrm{H}), 6.65-6.48(\mathrm{~m}, 1 \mathrm{H}), 6.52(\mathrm{t}, J=11.4 \mathrm{~Hz}, 1 \mathrm{H}), 6.15-6.07(\mathrm{~m}, 1 \mathrm{H}), 5.99(\mathrm{t}$, $J=11.0 \mathrm{~Hz}, 1 \mathrm{H}), 5.59(\mathrm{~d}, J=11.2 \mathrm{~Hz}, 1 \mathrm{H}), 5.57(\mathrm{t}, J=9.9 \mathrm{~Hz}, 1 \mathrm{H}), 5.31-5.15(\mathrm{~m}, 3 \mathrm{H}), 5.10(\mathrm{~m}$, 1H), 4.58-4.45 (m, 2H), 4.39 (m, 1H), 4.22-4.11 (m, 1H), $3.80(\mathrm{~s}, 3 \mathrm{H}), 3.71(\mathrm{~s}, 3 \mathrm{H}), 3.60(\mathrm{~m}, 1 \mathrm{H})$, 3.38-3.26 (m, 2H), $2.98(\mathrm{~m}, 1 \mathrm{H}), 2.52(\mathrm{~m}, 2 \mathrm{H}), 2.07(\mathrm{~m}, 2 \mathrm{H}), 1.78-0.75(\mathrm{~m}, 72 \mathrm{H}), 0.12-0.03(\mathrm{~s}$, $18 \mathrm{H}) ;{ }^{19} \mathrm{~F}$ NMR $\left(282 \mathrm{MHz}, \mathrm{CDCl}_{3}\right) \delta-79.5(3 \mathrm{~F}),-115.2(2 \mathrm{~F}),-120.7(6 \mathrm{~F}),-121.5(2 \mathrm{~F}),-121.8$ (2F), -124.9 (2F); MS (ESI) $m / z 1609.8[\mathrm{M}+\mathrm{Na}]^{+}$.

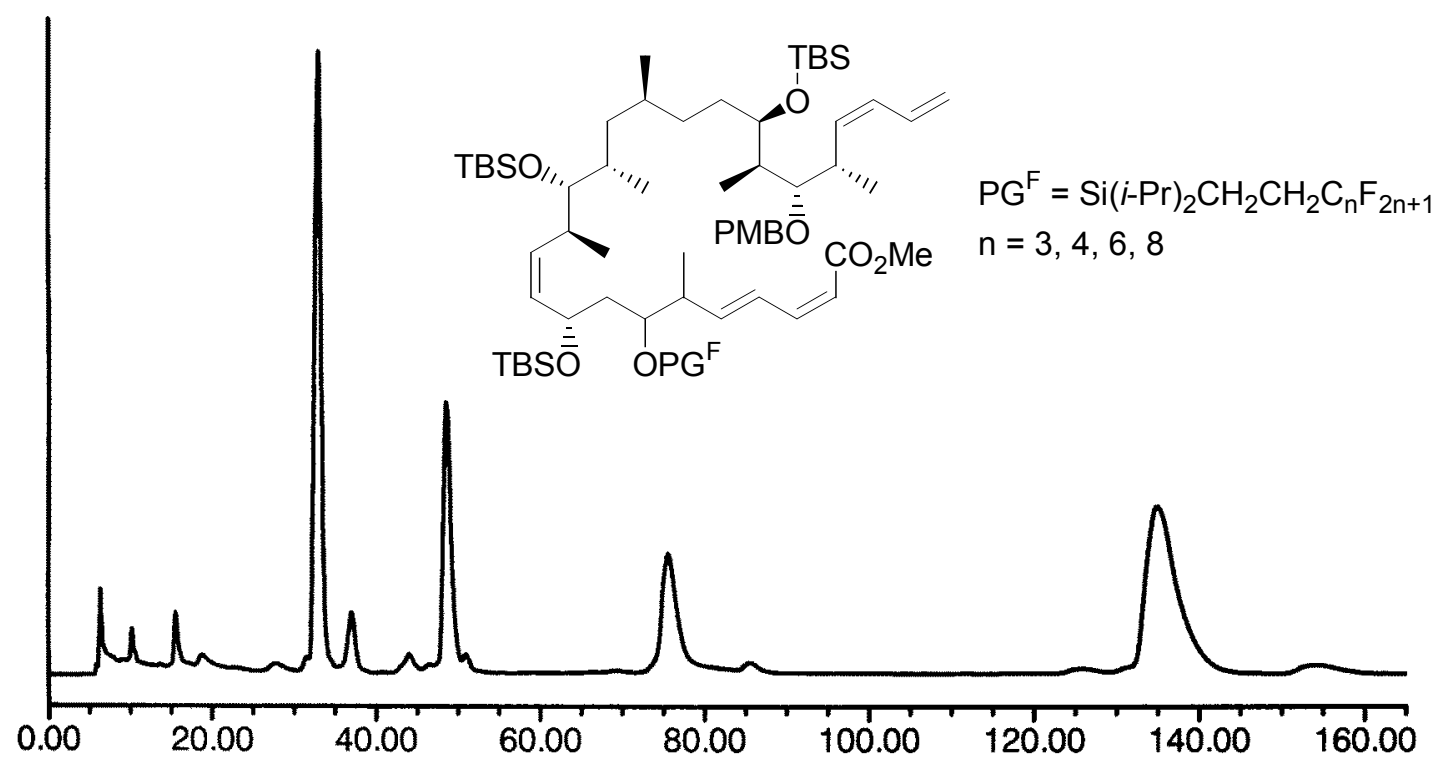

HPLC: FluoroFlash PF-C8 (Fluorous Technologies, Inc.) $20 \times 250 \mathrm{~mm}, 100 \mathrm{~A}, 5 \mu \mathrm{m}, \mathrm{UV}$ detection at $220 \mathrm{~nm}$, gradient elution from 100\% acetonitrile to $95: 5$ acetonitrile/THF in $40 \mathrm{~min}$ to $90: 10$ acetonitrile/THF in additional $5 \mathrm{~min}$ and isocratic 90:10 acetonitrile/THF for another 120 min. 21a $\left(\mathrm{C}_{3} \mathrm{~F}_{7}\right): 33.0 \mathrm{~min}, \mathbf{2 1 b}\left(\mathrm{C}_{4} \mathrm{~F}_{9}\right): 48.7 \mathrm{~min}, \mathbf{2 1 c}\left(\mathrm{C}_{6} \mathrm{~F}_{13}\right): 75.6 \mathrm{~min}, \mathbf{2 1 d}\left(\mathrm{C}_{8} \mathrm{~F}_{17}\right): 135.0$ $\min . \mathbf{2 1} \mathbf{a} / \mathbf{2 1} \mathbf{b} / \mathbf{1 2 1} \mathbf{c} / \mathbf{2 1 d}=2.3: 1.2: 1.0: 2.6$. 
Four-component mixture of methyl $(2 Z, 4 E, 9 S, 10 Z, 12 S, 13 R, 14 S, 16 S, 19 R, 20 R, 21 S, 22 S$, 23Z)-9,13,19-tris(tert-butyl-dimethylsilyloxy)-7-diisopropylperfluoroalkylethylsilyloxy-21-h ydroxy-6,12,14,16,20,22-hexamethylhexacosa-2,4,10,23,25-pentaenoate:

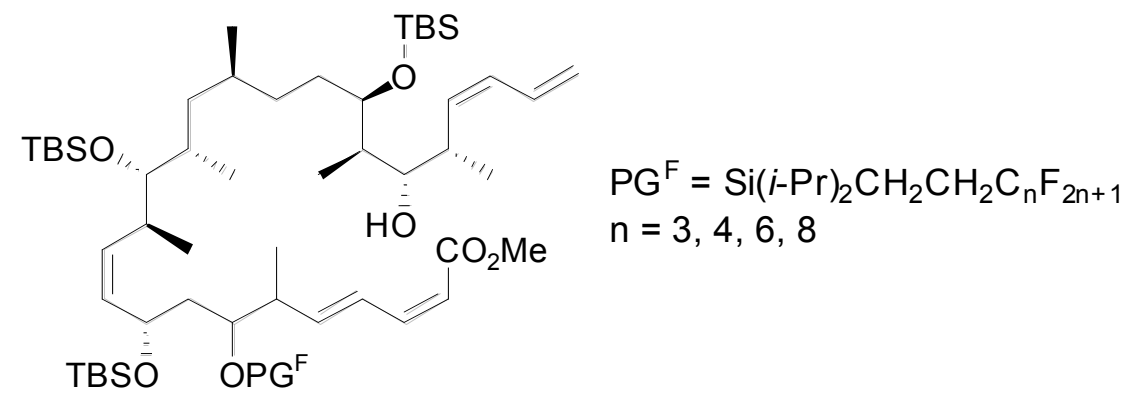

The ester M-21a-d (393 mg, $0.27 \mathrm{mmol})$ was added to $\mathrm{CH}_{2} \mathrm{Cl}_{2}(14 \mathrm{~mL})$ and $\mathrm{H}_{2} \mathrm{O}(0.7 \mathrm{~mL})$ and DDQ (68 mg, $0.30 \mathrm{mmol}$ ) was added at r.t. After $1 \mathrm{~h}$ of stirring at r.t, the reaction mixture was quenched by adding sat'd $\mathrm{NaHCO}_{3}(10 \mathrm{~mL})$. The organic phase was washed by sat'd $\mathrm{NaHCO}_{3}$ solution $(3 \times 10 \mathrm{~mL})$ and brine, dried over $\mathrm{MgSO}_{4}$ and concentrated. Purification by flash column chromatography (EtOAc/hexane 1:9) furnished the alcohol (329 mg, $91 \%$ ) as a colorless oil.

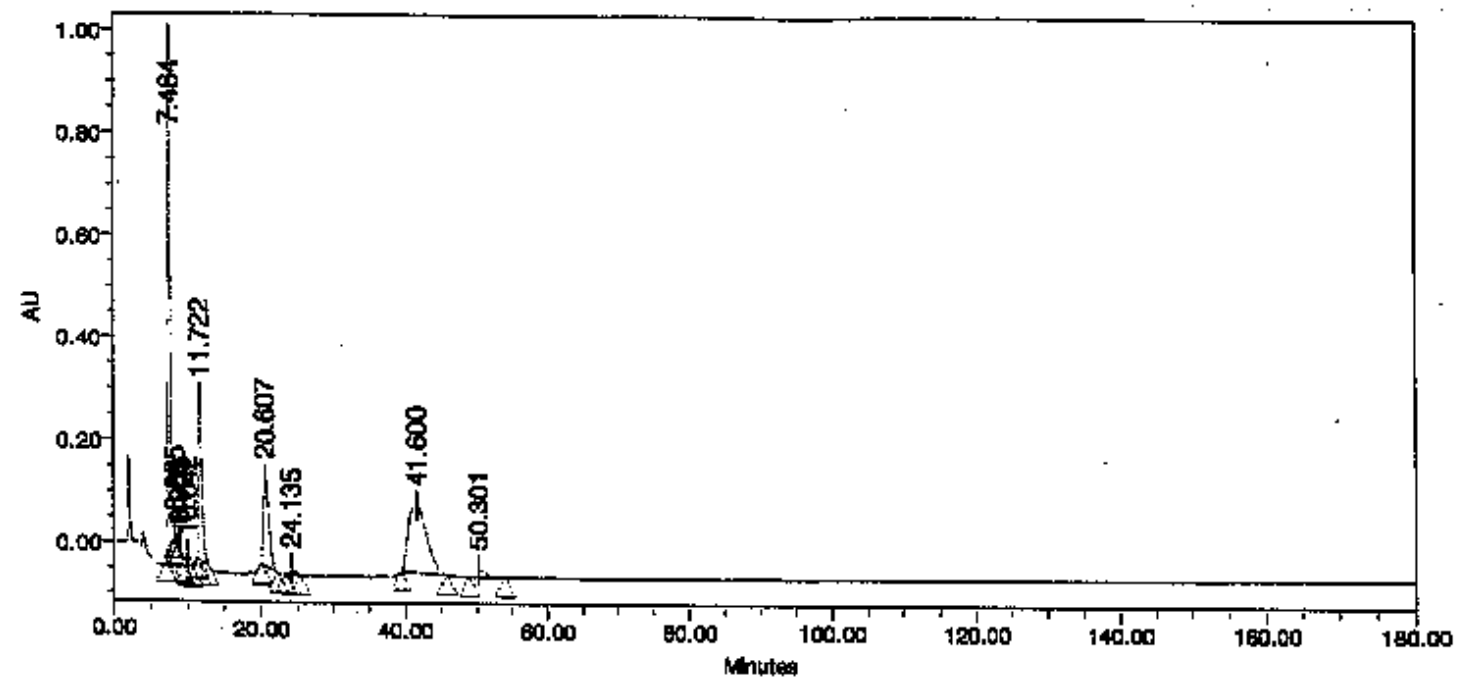

HPLC: FluoroFlash PF-C8 (Fluorous Technologies, Inc.) 4.6 × $150 \mathrm{~mm}, 100 \mathrm{~A}, 5 \mu \mathrm{m}, \mathrm{UV}$ detection at $220 \mathrm{~nm}$, isocratic elution 80:20 acetonitrile/THF for $180 \mathrm{~min} . \mathbf{a}\left(\mathrm{C}_{3} \mathrm{~F}_{7}\right)$ : $7.5 \mathrm{~min}, \mathbf{b}$ $\left(\mathrm{C}_{4} \mathrm{~F}_{9}\right): 11.7 \mathrm{~min}, \mathbf{c}\left(\mathrm{C}_{6} \mathrm{~F}_{13}\right): 20.6 \mathrm{~min}, \mathbf{d}\left(\mathrm{C}_{8} \mathrm{~F}_{17}\right): 41.6 \mathrm{~min} . \mathbf{a} / \mathbf{b} / \mathbf{c} / \mathbf{d}=2.6: 1.1: 1.0: 2.6$. 
Four-component mixture of $(2 Z, 4 E, 9 S, 10 Z, 12 S, 13 R, 14 S, 16 S, 19 R, 20 R, 21 S, 22 S, 23 Z)$ 9,13,19-tris(tert-butyldimethyl-silyloxy)-7-diisopropylperfluoroalkylethylsilyloxy-21hydroxy-6,12,14,16,20,22-hexamethylhexacosa-2,4,10,23,25-pentaenoic acid:

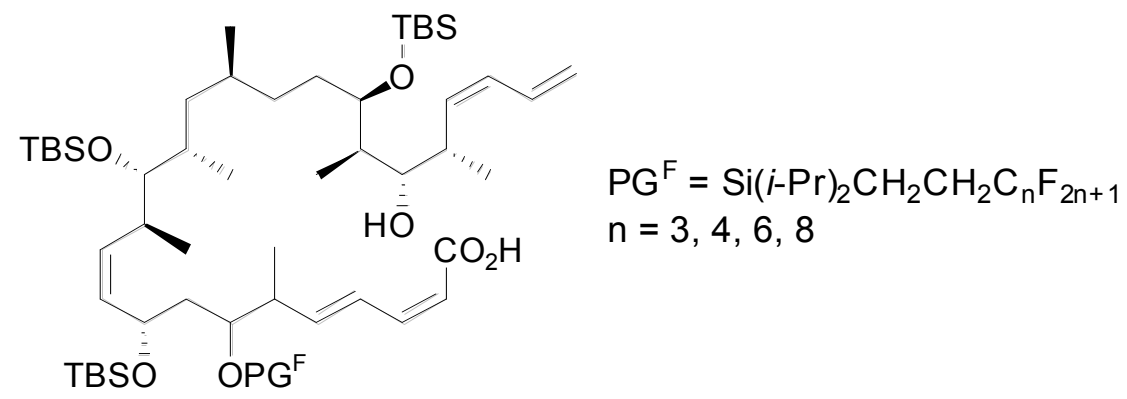

To the stirred solution of the above alcohol $(329 \mathrm{mg}, 0.25 \mathrm{mmol})$ in EtOH $(24 \mathrm{~mL})$, THF (2.5 $\mathrm{mL}$ ) was added $1 \mathrm{~N}$ aqueous $\mathrm{KOH}$ solution $(2.5 \mathrm{~mL})$ and the mixture was refluxed gently until the ester disappeared (about $13 \mathrm{~h}$ ) as determined by TLC analysis. The ethanolic solution was concentrated and then diluted with ether $(10 \mathrm{~mL})$. After the solution was acidified to $\mathrm{pH} 3$ with $1 \mathrm{~N} \mathrm{HCl}$ solution, organic phase was separated and aqueous phase was extracted with $\mathrm{Et}_{2} \mathrm{O}(2 \times 5$ $\mathrm{mL}$ ). The combined organic phase were dried with $\mathrm{MgSO}_{4}$, concentrated and used without further purification.

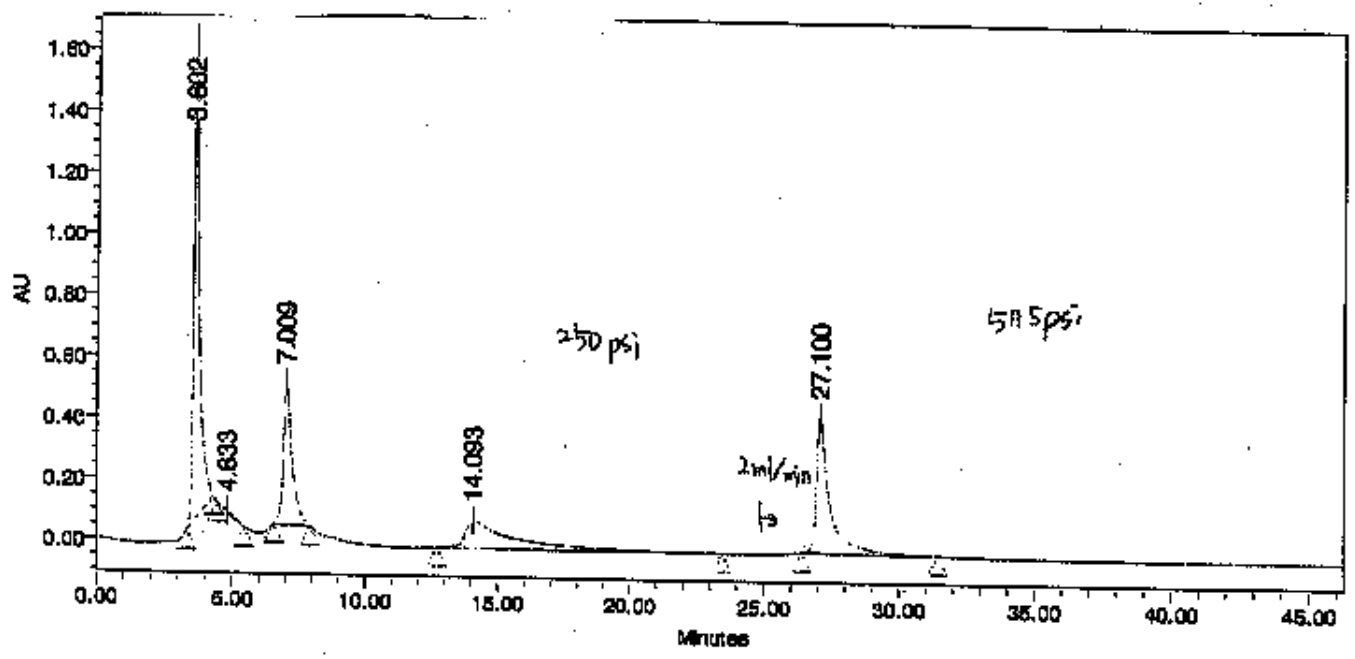


HPLC: FluoroFlash PF-C8 (Fluorous Technologies, Inc.) 4.6 x 150 mm, 100 A, $5 \mu \mathrm{m}$, UV detection at $220 \mathrm{~nm}$, isocratic elution 80:20 acetonitrile/THF for $46 \mathrm{~min}$. a $\left(\mathrm{C}_{3} \mathrm{~F}_{7}\right): 3.6 \mathrm{~min}$, b $\left(\mathrm{C}_{4} \mathrm{~F}_{9}\right): 7.0 \mathrm{~min}, \mathbf{c}\left(\mathrm{C}_{6} \mathrm{~F}_{13}\right): 14.1 \mathrm{~min}, \mathbf{d}\left(\mathrm{C}_{8} \mathrm{~F}_{17}\right): 27.1 \mathrm{~min} . \mathbf{a} / \mathbf{b} / \mathbf{c} / \mathbf{d}=2.2: 1.0: 1.1: 1.5$.

Four-component mixture of $(10 S, 13 S, 14 R, 15 S, 17 S, 20 R, 21 R, 22 S)-10,14,20$-tris(tert-butyldimethylsilyloxy)-8-diisopro-pylperfluoroalkylethylsilyloxy-7,13,15,17,21-penta-methyl-22-[ (1S,2Z)-1-methylpenta-2,4-dienyl]oxacyclodocosa-3,5,11-trien-2-one:

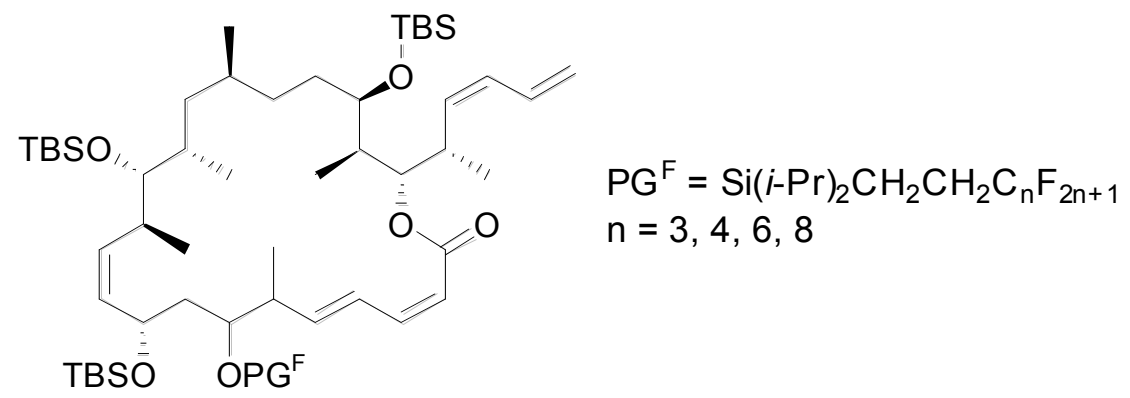

A solution of the above acid in THF $(5 \mathrm{~mL})$ was treated at $0{ }^{\circ} \mathrm{C}$ with $\mathrm{Et}_{3} \mathrm{~N}(0.21 \mathrm{~mL}, 1.50 \mathrm{mmol})$ and 2,4,6-trichlorobenzoyl chloride $(0.19 \mathrm{~mL}, 1.22 \mathrm{mmol})$. The reaction mixture was stirred at 0 ${ }^{\circ} \mathrm{C}$ for $30 \mathrm{~min}$ and then added to 4-DMAP (123 mL, $0.02 \mathrm{M}$ solution in toluene) at $25{ }^{\circ} \mathrm{C}$. After stirring $12 \mathrm{~h}$, the reaction mixture was concentrated, $\mathrm{Et}_{2} \mathrm{O}(10 \mathrm{~mL})$ was added and the crude was washed with $1 \mathrm{~N} \mathrm{HCl}(2 \times 5 \mathrm{~mL})$ and dried over $\mathrm{MgSO}_{4}$. Purification by flash column chromatography (EtOAc/hexane 2:98) furnished macrolactone as a colorless oil. The mixture was demixed by semipreparative HPLC (FluoroFlash PF-C8 (Fluorous Technologies, Inc.) $20 \mathrm{x}$ $250 \mathrm{~mm}, 100 \mathrm{~A}, 5 \mu \mathrm{m}$, isocratic elution of acetonitrile/THF 80:20 for $140 \mathrm{~min}$ ) to give a (73 $\mathrm{mg}$, 25\%, HRMS (ESI) calcd for $\mathrm{C}_{61} \mathrm{H}_{111} \mathrm{O}_{6} \mathrm{Na}_{1} \mathrm{Si}_{4} \mathrm{~F}_{7}[\mathrm{M}+\mathrm{Na}]^{+}$1207.7244, found 1207.7223), b (31 mg, 10\%, HRMS (ESI) calcd for $\mathrm{C}_{62} \mathrm{H}_{112} \mathrm{O}_{6} \mathrm{Si}_{4} \mathrm{~F}_{9}[\mathrm{M}]^{+}$1235.7392, found 1235.7432), c (26mg, 8\%, HRMS (ESI) calcd for $\mathrm{C}_{64} \mathrm{H}_{111} \mathrm{O}_{6} \mathrm{Na}_{1} \mathrm{Si}_{4} \mathrm{~F}_{13}[\mathrm{M}+\mathrm{Na}]^{+}$1357.7148, found 1357.7094), and $\mathbf{d}$ (56 mg, 16\%, HRMS (ESI) calcd for $\mathrm{C}_{66} \mathrm{H}_{111} \mathrm{O}_{6} \mathrm{Na}_{1} \mathrm{Si}_{4} \mathrm{~F}_{17}[\mathrm{M}+\mathrm{Na}]^{+}$1457.7084, found 1457.7017), which were mixtures of $(E, Z)$ and isomerized $(E, E)$. 


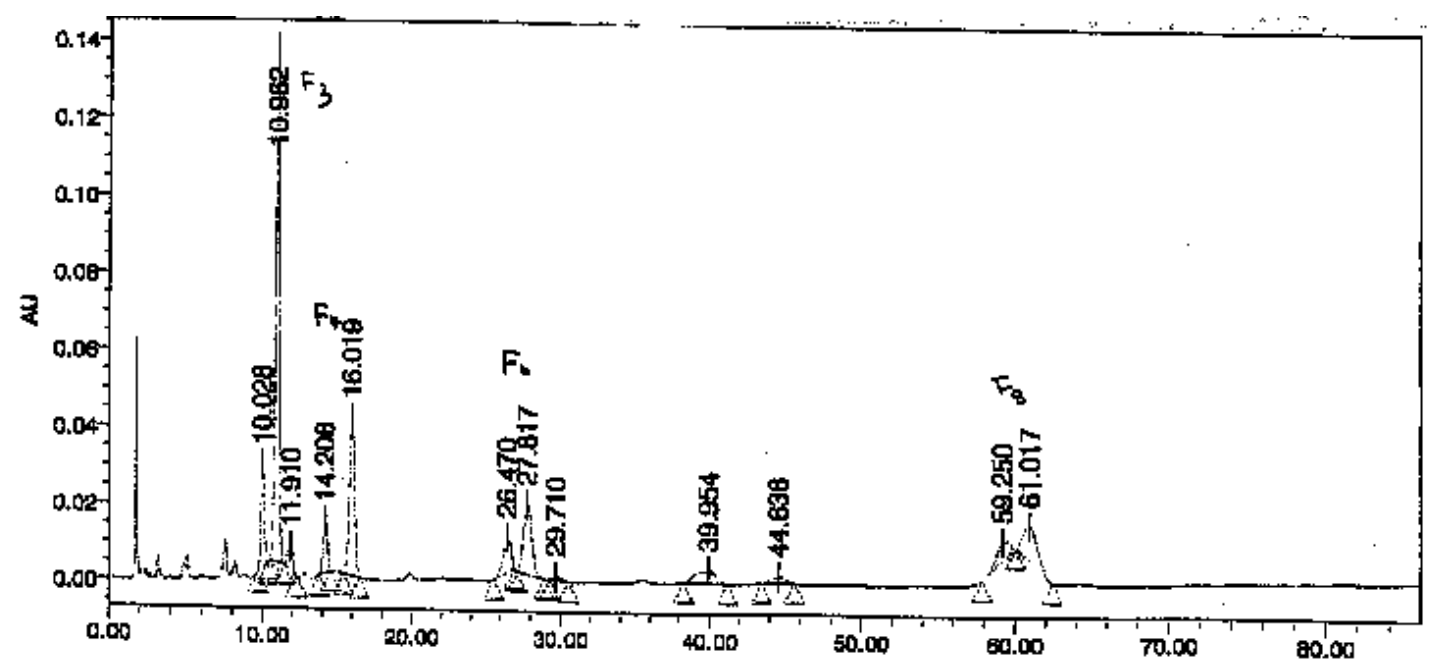

HPLC: FluoroFlash PF-C8 (Fluorous Technologies, Inc.) 4.6 x $150 \mathrm{~mm}, 100 \mathrm{~A}, 5 \mu \mathrm{m}, \mathrm{UV}$ detection at $220 \mathrm{~nm}$, isocratic elution 80:20 acetonitrile/THF for $180 \mathrm{~min} . \mathbf{a}\left(\mathrm{C}_{3} \mathrm{~F}_{7}\right): 10.9 \mathrm{~min}, \mathbf{b}$ $\left(\mathrm{C}_{4} \mathrm{~F}_{9}\right)$ : $16.0 \mathrm{~min}, \mathbf{c}\left(\mathrm{C}_{6} \mathrm{~F}_{13}\right): 27.8 \mathrm{~min}, \mathbf{d}\left(\mathrm{C}_{8} \mathrm{~F}_{17}\right): 61.0 \mathrm{~min} . \mathbf{a} / \mathbf{b} / \mathbf{c} / \mathbf{d}=3.9: 1.5: 1.4: 1.0$.

\section{Dictyostatin $(6 R, 7 S)-1$ :}

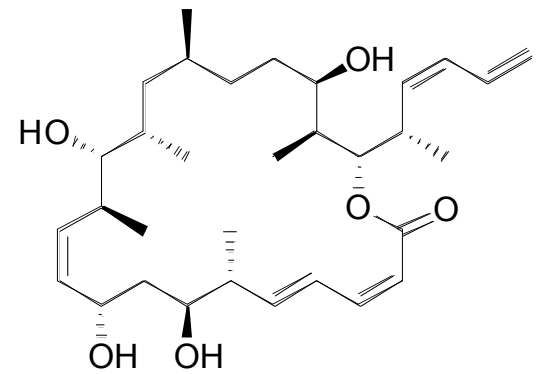

To a stirred solution of the above macrolactone $21 \mathrm{a}(73 \mathrm{mg}, 62 \mu \mathrm{mol})$ in THF $(3 \mathrm{~mL})$ at $0{ }^{\circ} \mathrm{C}$ was

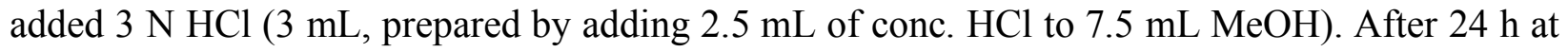
room temperature, the reaction mixture was diluted with EtOAc $(4 \mathrm{~mL})$ and $\mathrm{H}_{2} \mathrm{O}(4 \mathrm{~mL})$ and the organic phase was separated and aqueous phase was extracted with EtOAc $(2 \times 4 \mathrm{~mL})$. The combined organic phase was washed with sat'd $\mathrm{NaHCO}_{3}(10 \mathrm{~mL})$, dried with $\mathrm{MgSO}_{4}$, concentrated and the residue was purified by flash chromatography (EtOAc/hexane 3:2) to yield the dictyostatin as a white solid (13.1 mg, $40 \%)$. The structure was confirmed by TLC (60\% 
ethyl acetate- $40 \%$ hexane) and by ${ }^{1} \mathrm{H}$ NMR spectrum comparison with the synthetic dictyostatin sample previously reported.

\section{6,7-bis-epi-Dictyostatin (6S,7R)-22:}

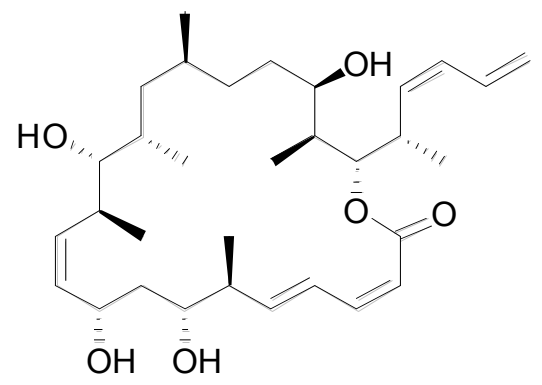

The procedure for dictyostatin was used with $21 \mathrm{~b}(31 \mathrm{mg}, 25 \mu \mathrm{mol}), 3 \mathrm{~N} \mathrm{HCl}$ in $\mathrm{MeOH}(2 \mathrm{~mL})$ and THF ( $2 \mathrm{~mL})$ to yield 6,7-bis-epi-dictyostatin $(1.1 \mathrm{mg}, 8 \%$ ) by flash column chromatography (EtOAc/hexane 4:6) as a colorless oil (YF-50): ${ }^{1} \mathrm{H}$ NMR (500 MHz, $\left.\mathrm{CD}_{3} \mathrm{OD}\right) \delta 7.34$ (dd, $J=$ 15.1, 11.3 Hz, 1H), 6.64 (ddd, $J=16.6,10.9,10.7 \mathrm{~Hz}, 1 \mathrm{H}), 6.57$ (t, $J=11.4 \mathrm{~Hz}, 1 \mathrm{H}), 5.96(\mathrm{t}, J=$ $11.1 \mathrm{~Hz}, 1 \mathrm{H}), 5.95(\mathrm{dd}, J=15.0,8.8 \mathrm{~Hz}, 1 \mathrm{H}), 5.49$ (t, $J=8.0,1 \mathrm{H}), 5.48(\mathrm{~d}, J=11.1 \mathrm{~Hz}, 1 \mathrm{H})$, $5.38(\mathrm{dd}, J=11.1,8.9 \mathrm{~Hz}, 1 \mathrm{H}), 5.27(\mathrm{t}, J=10.3 \mathrm{~Hz}, 1 \mathrm{H}), 5.16(\mathrm{~d}, J=16.9 \mathrm{~Hz}, 1 \mathrm{H}), 5.08$ (d, $J=$ $10.2 \mathrm{~Hz}, 1 \mathrm{H}), 5.02(\mathrm{dd}, J=8.0,3.4 \mathrm{~Hz}, 1 \mathrm{H}), 4.65(\mathrm{~m}, 1 \mathrm{H}), 3.72(\mathrm{~m}, 1 \mathrm{H}), 3.16(\mathrm{~m}, 1 \mathrm{H}), 3.07(\mathrm{~m}$, 1H), $2.72(\mathrm{~m}, 1 \mathrm{H}), 2.36(\mathrm{~m}, 1 \mathrm{H}), 1.82(\mathrm{~m}, 1 \mathrm{H}), 1.70(\mathrm{~m}, 1 \mathrm{H}), 1.64-1.54(\mathrm{~m}, 3 \mathrm{H}), 1.46$ (ddd, $J=$ 13.6, 10.1, 3.2 Hz, 1H), 1.37-1.20 (m, 3H), 1.15 (m, 2H), 1.09 (d, $J=6.8 \mathrm{~Hz}, 3 \mathrm{H}), 1.03$ (d, $J=$ $6.7 \mathrm{~Hz}, 3 \mathrm{H}), 0.98(\mathrm{~d}, J=6.7 \mathrm{~Hz}, 3 \mathrm{H}), 0.89(\mathrm{~m}, 1 \mathrm{H}), 0.86(\mathrm{~d}, J=6.6 \mathrm{~Hz}, 3 \mathrm{H}), 0.76(\mathrm{~d}, J=6.4 \mathrm{~Hz}$, $3 \mathrm{H}) ; \mathrm{IR}\left(\mathrm{CHCl}_{3}\right) 3397,2922,2851,1701,1460,1181 ;[\alpha]_{\mathrm{D}}^{25}=+38.0(c 0.05, \mathrm{MeOH}) ; \mathrm{MS}(\mathrm{ESI})$ $m / z 555.3[\mathrm{M}+\mathrm{Na}]^{+}$; HRMS (ESI) calcd for $\mathrm{C}_{32} \mathrm{H}_{52} \mathrm{O}_{6} \mathrm{Na}[\mathrm{M}+\mathrm{Na}]^{+}$555.3662, found 555.3647. 


\section{6-epi-Dictyostatin $(6 S, 7 S)-23$ :}

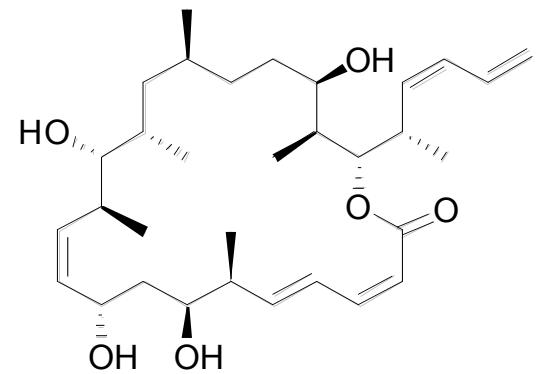

The procedure for dictyostatin was used with $21 \mathrm{c}(26 \mathrm{mg}, 19 \mu \mathrm{mol}), 3 \mathrm{~N} \mathrm{HCl}$ in $\mathrm{MeOH}(2 \mathrm{~mL})$ and THF (2 mL) to yield 6-epi-dictyostatin $(2.3 \mathrm{mg}, 22 \%)$ by flash column chromatography (EtOAc/hexane 4:6) as a colorless oil (YF-51): ${ }^{1} \mathrm{H}$ NMR $\left(500 \mathrm{MHz}, \mathrm{CD}_{3} \mathrm{OD}\right) \delta 7.21(\mathrm{dd}, J=$ $15.1,11.3 \mathrm{~Hz}, 1 \mathrm{H}), 6.65(\mathrm{ddd}, J=16.7,10.9,10.6 \mathrm{~Hz}, 1 \mathrm{H}), 6.54(\mathrm{t}, J=11.3 \mathrm{~Hz}, 1 \mathrm{H}), 5.98(\mathrm{t}, J=$ $11.0 \mathrm{~Hz}, 1 \mathrm{H}), 5.76(\mathrm{dd}, J=15.1,10.1 \mathrm{~Hz}, 1 \mathrm{H}), 5.50(\mathrm{~d}, J=11.2 \mathrm{~Hz}, 1 \mathrm{H}), 5.46(\mathrm{t}, J=9.9 \mathrm{~Hz}, 1 \mathrm{H})$, $5.30(\mathrm{dd}, J=11.0,8.7 \mathrm{~Hz}, 1 \mathrm{H}), 5.21(\mathrm{t}, J=10.4 \mathrm{~Hz}, 1 \mathrm{H}), 5.18(\mathrm{~d}, J=17.3 \mathrm{~Hz}, 1 \mathrm{H}), 5.10(\mathrm{~d}, J=$ $10.3 \mathrm{~Hz}, 1 \mathrm{H}), 5.03(\mathrm{dd}, J=9.1,2.8 \mathrm{~Hz}, 1 \mathrm{H}), 4.65(\mathrm{~m}, 1 \mathrm{H}), 3.55(\mathrm{~m}, 1 \mathrm{H}), 3.07-3.00(\mathrm{~m}, 2 \mathrm{H}), 2.92$ (t, $J=8.9 \mathrm{~Hz}, 1 \mathrm{H}), 2.67(\mathrm{~m}, 1 \mathrm{H}), 2.20-2.09(\mathrm{~m}, 2 \mathrm{H}), 1.84(\mathrm{~m}, 1 \mathrm{H}), 1.71(\mathrm{~m}, 1 \mathrm{H}), 1.58(\mathrm{~m}, 1 \mathrm{H})$, $1.53(\mathrm{~m}, 1 \mathrm{H}), 1.46(\mathrm{~m}, 1 \mathrm{H}), 1.33(\mathrm{ddd}, J=13.9,11.1,2.6 \mathrm{~Hz}, 1 \mathrm{H}), 1.22(\mathrm{~m}, 1 \mathrm{H}), 1.15(\mathrm{~d}, J=6.5$ $\mathrm{Hz}, 3 \mathrm{H}), 1.07$ (d, $J=6.7 \mathrm{~Hz}, 3 \mathrm{H}), 1.06(\mathrm{~d}, J=6.9 \mathrm{~Hz}, 3 \mathrm{H}), 0.98(\mathrm{~d}, J=6.3 \mathrm{~Hz}, 3 \mathrm{H}), 0.97(\mathrm{~d}, J=$ $6.3 \mathrm{~Hz}, 3 \mathrm{H}), 0.93(\mathrm{~d}, J=6.4 \mathrm{~Hz}, 3 \mathrm{H}), 0.91-0.80(\mathrm{~m}, 2 \mathrm{H}), 0.37(\mathrm{~m}, 1 \mathrm{H}) ;{ }^{13} \mathrm{C} \mathrm{NMR}(125 \mathrm{MHz}$, $\left.\mathrm{CD}_{3} \mathrm{OD}\right) \delta 167.3,147.4,144.9,135.4,135.0,133.6,131.3,130.0,128.5,118.2,117.7,80.5,77.2$, $75.0,71.5,65.2,44.7,41.9,41.7,35.8,35.3,35.2,33.7,32.7,31.5,22.2,19.2,18.3,17.2,16.3$, 10.0; IR $\left(\mathrm{CHCl}_{3}\right) 3349,2962,2924,1710,1637,1459,1176,1117,965 ;[\alpha]_{\mathrm{D}}{ }^{25}=+11.4(c 0.11$, $\mathrm{MeOH}) ; \mathrm{MS}$ (ESI) $m / z 555.3[\mathrm{M}+\mathrm{Na}]^{+}$; HRMS (ESI) calcd for $\mathrm{C}_{32} \mathrm{H}_{52} \mathrm{O}_{6} \mathrm{Na}[\mathrm{M}+\mathrm{Na}]^{+}$ 555.3662, found 555.3652. 


\section{7-epi-Dictyostatin $(6 R, 7 R)-24:$}

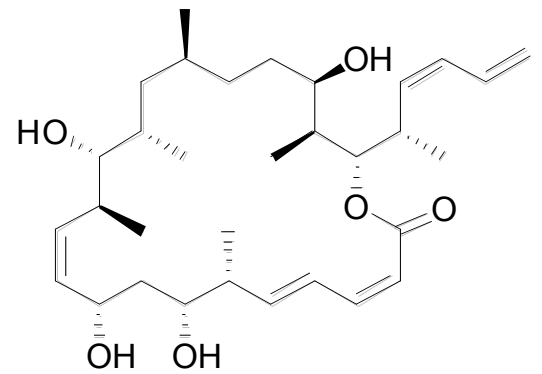

The procedure for dictyostatin was used with $\mathbf{2 1 d}(56 \mathrm{mg}, 39 \mu \mathrm{mol}), 3 \mathrm{~N} \mathrm{HCl}$ in $\mathrm{MeOH}(2 \mathrm{~mL})$ and THF $(2 \mathrm{~mL})$ to yield 7-epi-dictyostatin $(6.0 \mathrm{mg}, 29 \%)$ by flash column chromatography (EtOAc/hexane 4:6) as a colorless oil (YF-52): ${ }^{1} \mathrm{H}$ NMR $\left(500 \mathrm{MHz}, \mathrm{CD}_{3} \mathrm{OD}\right) \delta 7.36(\mathrm{dd}, J=$ 15.7, $11.3 \mathrm{~Hz}, 1 \mathrm{H}), 6.64(\mathrm{ddd}, J=16.5,10.5,10.3 \mathrm{~Hz}, 1 \mathrm{H}), 6.59$ (t, $J=11.3 \mathrm{~Hz}, 1 \mathrm{H}), 6.26(\mathrm{dd}, J$ $=15.8,5.4 \mathrm{~Hz}, 1 \mathrm{H}), 5.97(\mathrm{t}, J=10.9 \mathrm{~Hz}, 1 \mathrm{H}), 5.48(\mathrm{t}, J=10.6 \mathrm{~Hz}, 1 \mathrm{H}), 5.47(\mathrm{~d}, J=11.2 \mathrm{~Hz}$, 1H), $5.28(\mathrm{~d}, J=10.6 \mathrm{~Hz}, 1 \mathrm{H}), 5.18(\mathrm{t}, J=10.0 \mathrm{~Hz}, 1 \mathrm{H}), 5.17(\mathrm{~d}, J=16.7 \mathrm{~Hz}, 1 \mathrm{H}), 5.09(\mathrm{~d}, J=$ $10.2 \mathrm{~Hz}, 1 \mathrm{H}), 4.96(\mathrm{dd}, J=8.8,2.6 \mathrm{~Hz}, 1 \mathrm{H}), 4.59(\mathrm{dd}, J=16.2,7.2 \mathrm{~Hz}, 1 \mathrm{H}), 3.96(\mathrm{~m}, 1 \mathrm{H})$, 3.22-3.18 (m, 2H), $3.04(\mathrm{~m}, 1 \mathrm{H}), 2.71(\mathrm{~m}, 1 \mathrm{H}), 2.42(\mathrm{~m}, 1 \mathrm{H}), 1.89-1.79(\mathrm{~m}, 3 \mathrm{H}), 1.72-1.62(\mathrm{~m}$, $3 \mathrm{H}), 1.59-1.51(\mathrm{~m}, 2 \mathrm{H}), 1.45-1.39(\mathrm{~m}, 1 \mathrm{H}), 1.37-1.33(\mathrm{~m}, 1 \mathrm{H}), 1.07(\mathrm{~d}, J=6.9 \mathrm{~Hz}, 6 \mathrm{H}), 1.01(\mathrm{~d}$, $J=6.8 \mathrm{~Hz}, 3 \mathrm{H}), 0.98(\mathrm{~d}, J=6.7 \mathrm{~Hz}, 3 \mathrm{H}), 0.94(\mathrm{~d}, J=6.6 \mathrm{~Hz}, 3 \mathrm{H}), 0.92(\mathrm{~d}, J=6.8 \mathrm{~Hz}, 3 \mathrm{H})$, 0.88-0.82 (m, 1H); ${ }^{13} \mathrm{H}$ NMR (125 MHz, CD 3 OD) $\delta 167.7, ~ 148.6,147.2,135.1,133.5,132.9$, $131.4,126.9,118.4,116.7,111.0,78.4,77.4,74.1,73.3,68.2,42.4,41.8,40.2,36.2,36.0,34.1$, 33.2, 32.2, 31.3, 22.0, 18.7, 17.5, 15.2, 14.2, 10.4; IR $\left(\mathrm{CHCl}_{3}\right)$ 3399, 2963, 2925, 2872, 1694, 1633, 1459, 1377, 1184, 958; $[\alpha]_{\mathrm{D}}^{25}=+96.8\left(c\right.$ 0.22, MeOH); MS (ESI) $m / z 555.3[\mathrm{M}+\mathrm{Na}]^{+}$; HRMS (ESI) calcd for $\mathrm{C}_{32} \mathrm{H}_{52} \mathrm{O}_{6} \mathrm{Na}[\mathrm{M}+\mathrm{Na}]^{+}$555.3662, found 555.3646. 
${ }^{1} \mathrm{H}$ NMR Spectrum of Dictyostatin $\left(\mathrm{CDCl}_{3}\right)$
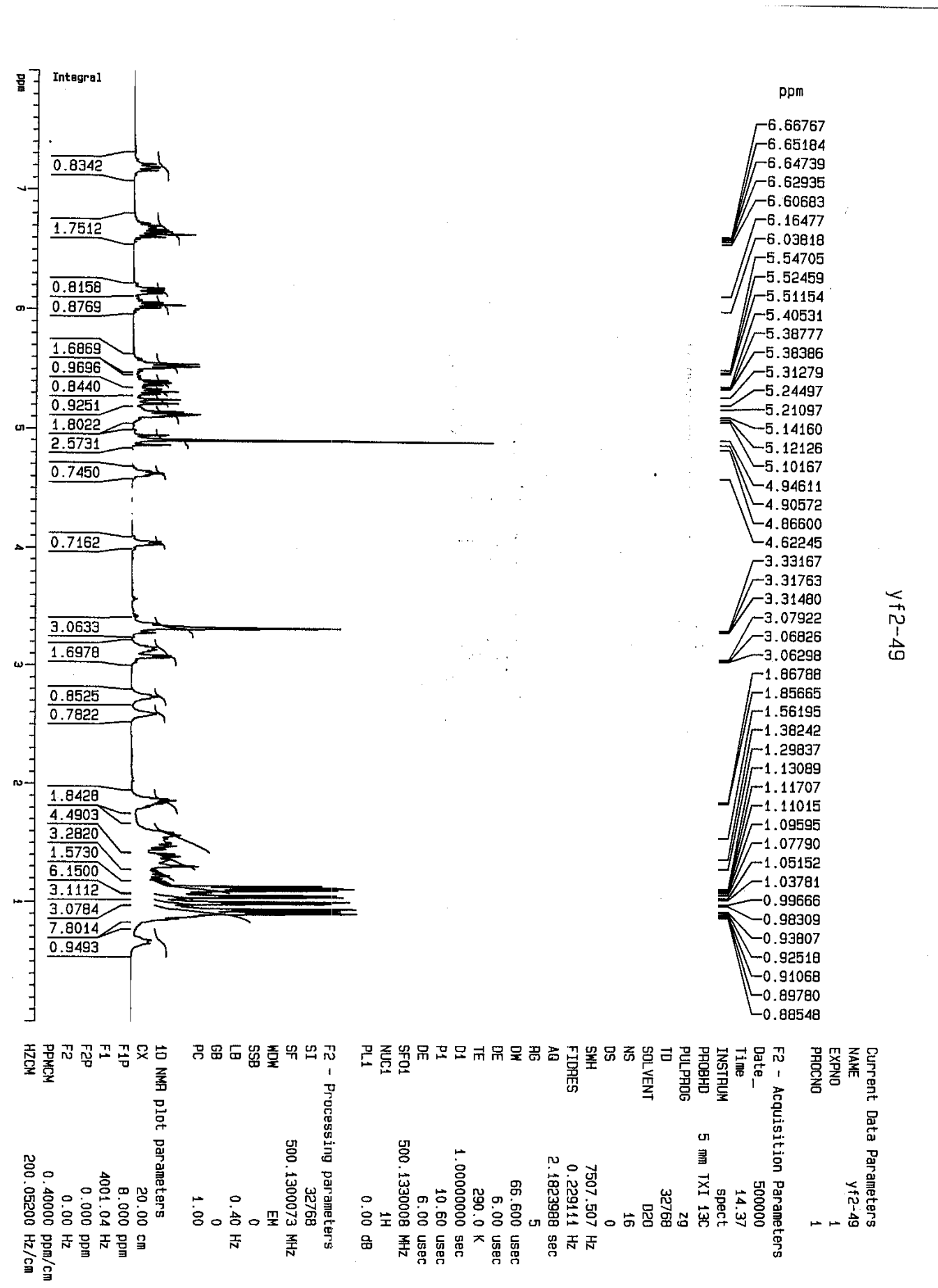
${ }^{1} \mathrm{H}$ NMR Spectrum of 6,7-bis-epi-Dictyostatin $\left(\mathrm{CDCl}_{3}\right)$
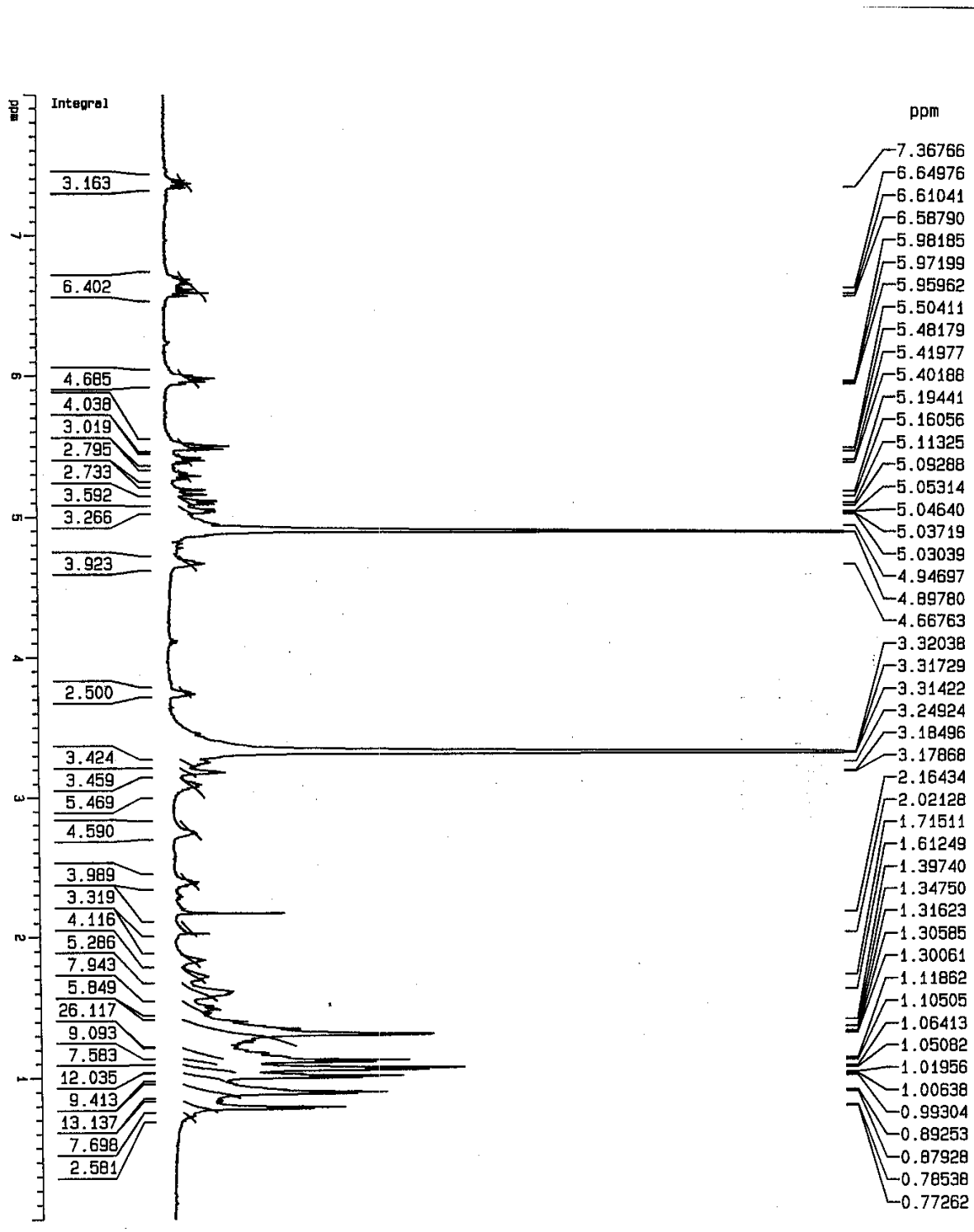

5.95962

$\sqrt{-5.50411}$

$r_{-5.41977}^{5.40189}$

$\Gamma^{5.19441}$

$-5.16056$

- $r^{5.11325}$

$-5.04340$

-04379
-5.03719

$\sqrt{-5.03099}-4.94697$

$-4.66763$

$\overbrace{}^{-3.35038}$

$r_{-3.31422}^{-3.31729}$

$-3.24924$

$-3.18496$

$-3.17868$

$-2.16434$

$-1.71511$

$-1.61249$

每 $\begin{array}{r}-1.39740 \\ -1.34750\end{array}$

]

] -1.30585

$\left[\begin{array}{r}1.30585 \\ -1.30061 \\ -1.11862\end{array}\right.$

-1) $r^{-1.11862}$

$-1.10505$

$-1.06413$

$-_{1.01956}^{1.05082}$

$-1.00630$

-0.99304

$-0.89253$

$-0.78538$

$L_{0.77262}$

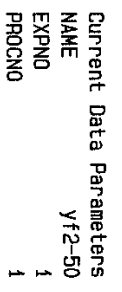


${ }^{1} \mathrm{H}$ NMR Spectrum of 6-epi-Dictyostatin $\left(\mathrm{CDCl}_{3}\right)$

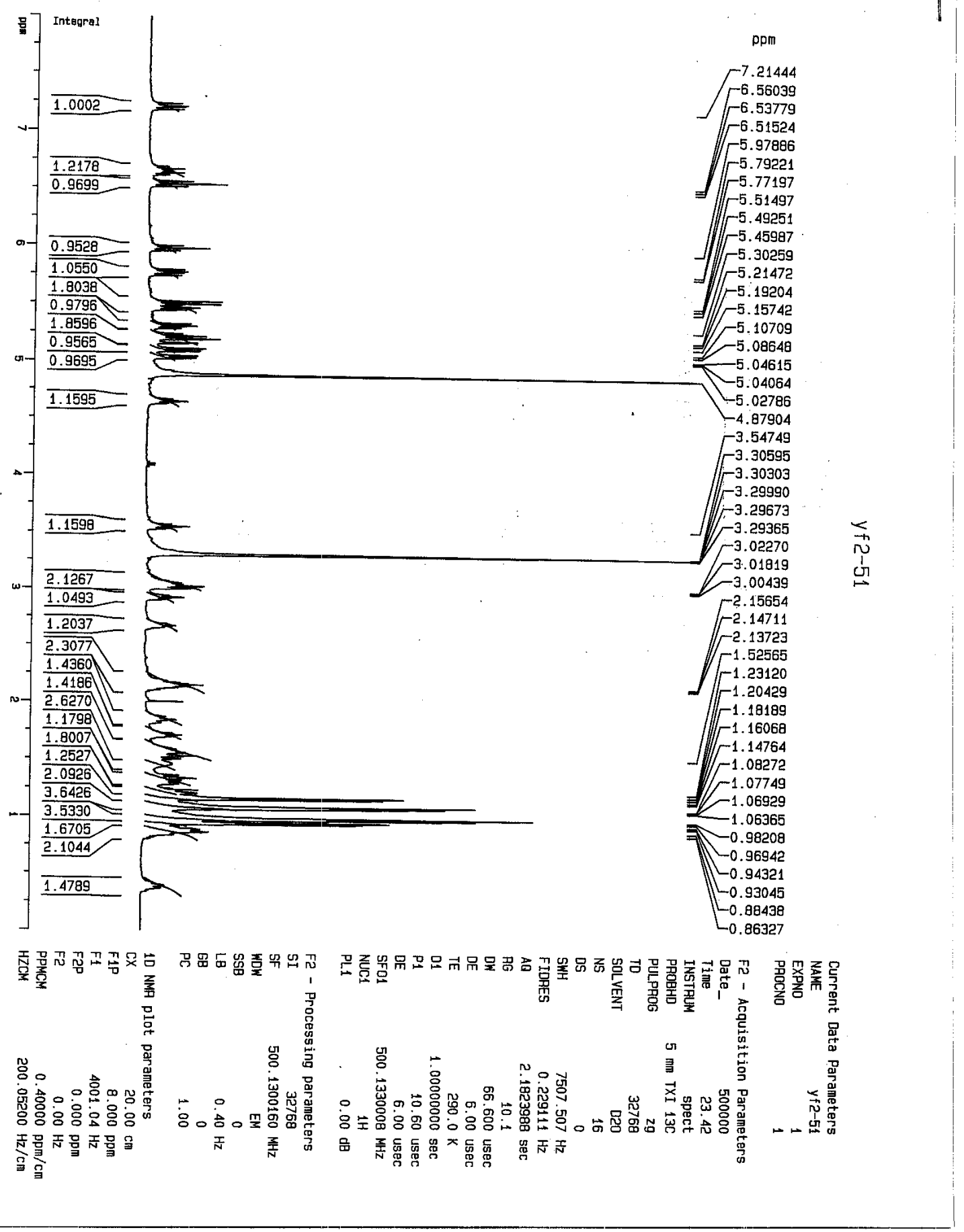


${ }^{13} \mathrm{C}$ NMR Spectrum of 6-epi-Dictyostatin $\left(\mathrm{CDCl}_{3}\right)$

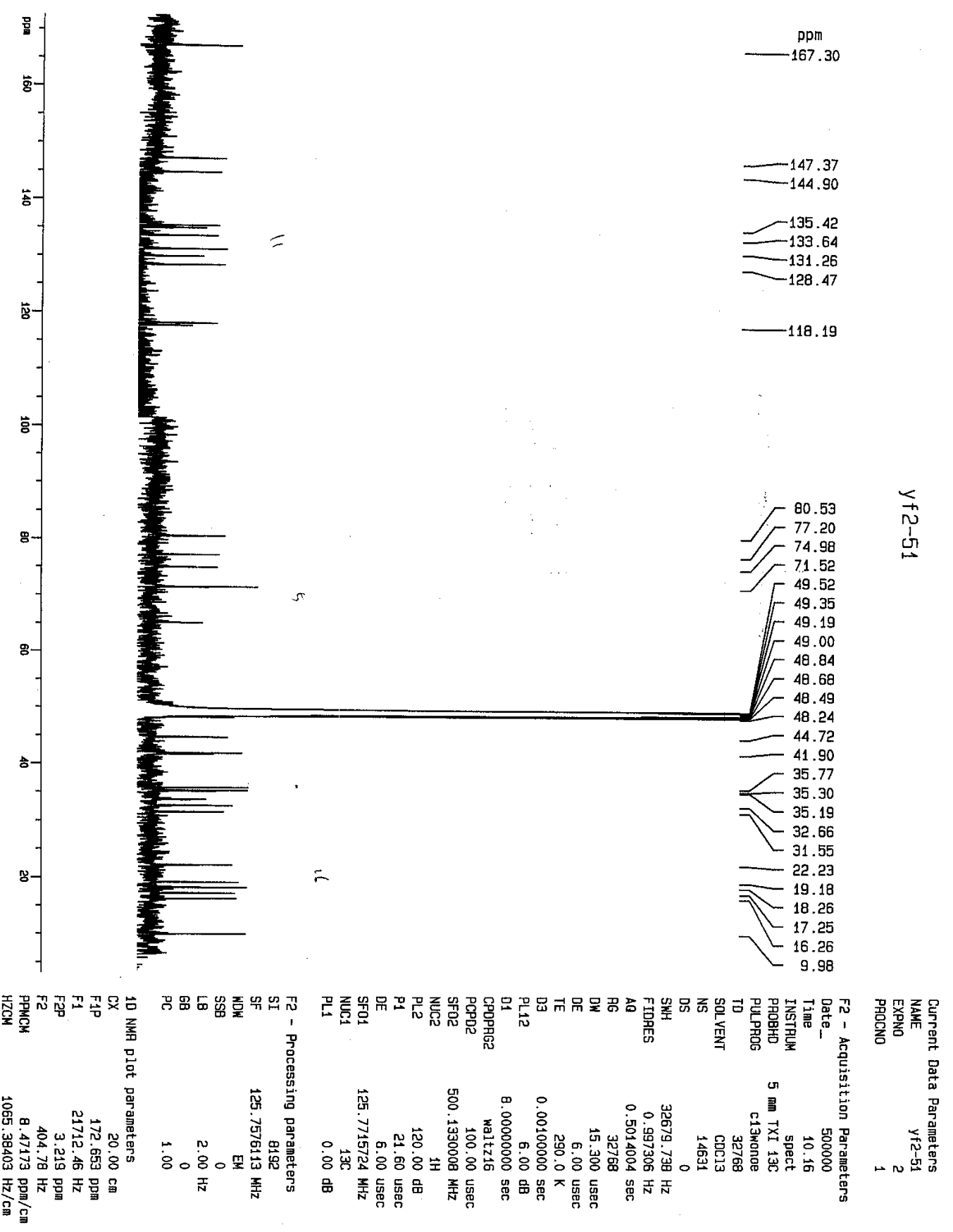


${ }^{1} \mathrm{H}$ NMR Spectrum of 7-epi-Dictyostatin $\left(\mathrm{CDCl}_{3}\right)$

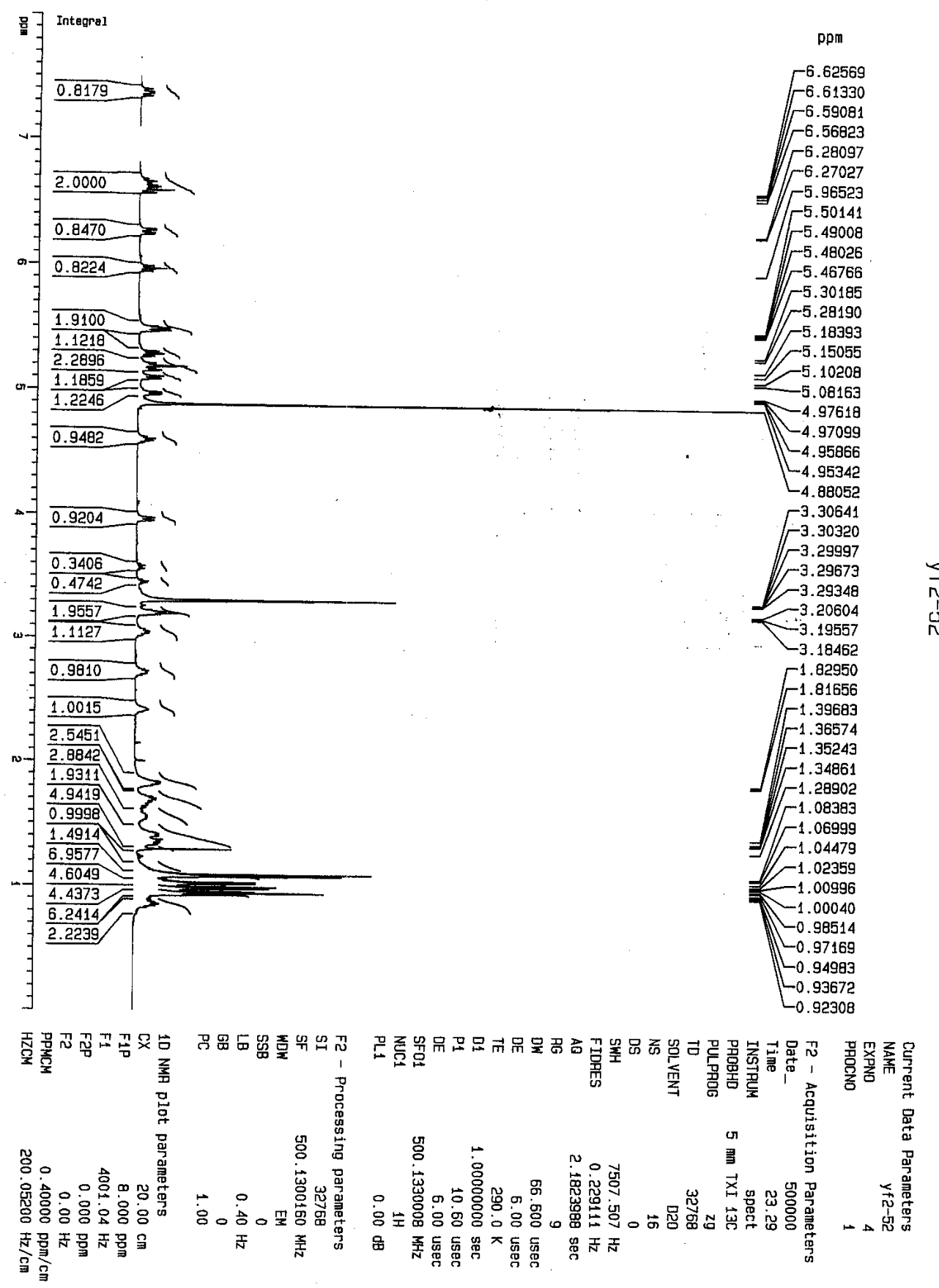




\section{${ }^{13} \mathrm{C}$ NMR Spectrum of 7-epi-Dictyostatin $\left(\mathrm{CDCl}_{3}\right)$}
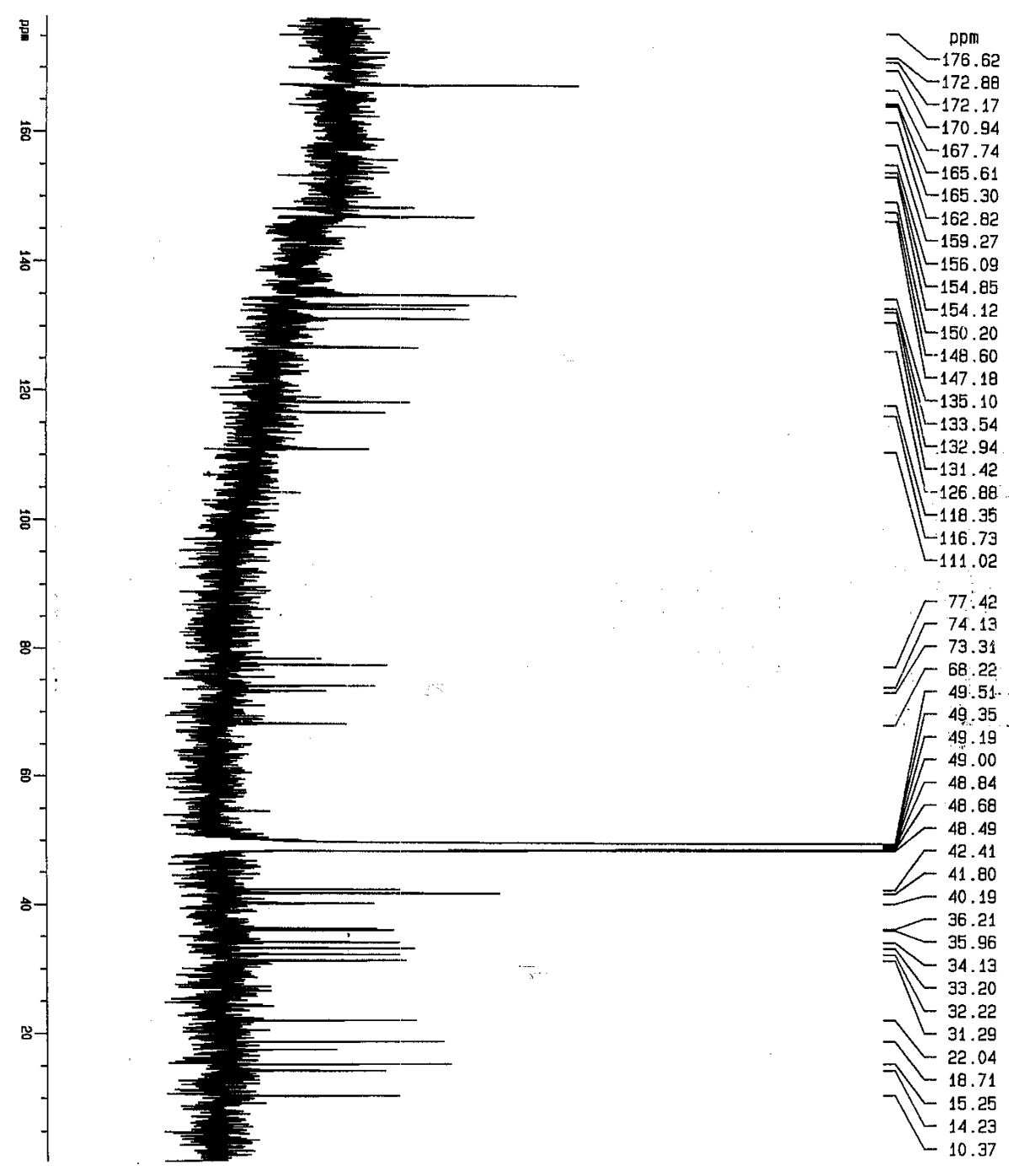

$77: 42$

74.13

$F^{73.31}$ 兒

$=\tau^{49.51 .}$

- 49.35

F 49.19

$F^{49.00}$

$\int \Gamma^{48.84} 48.60$

- 48.49

42.41

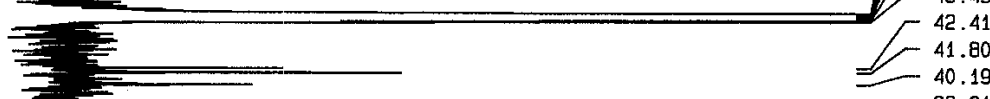

41.80
40.19

${ }^{36.2}$

$\widehat{ح-34.96}$

- 33.20

$-32.22$

$-31.29$

$-22.04$

$-18.71$

$-15.25$

14.23
10.37

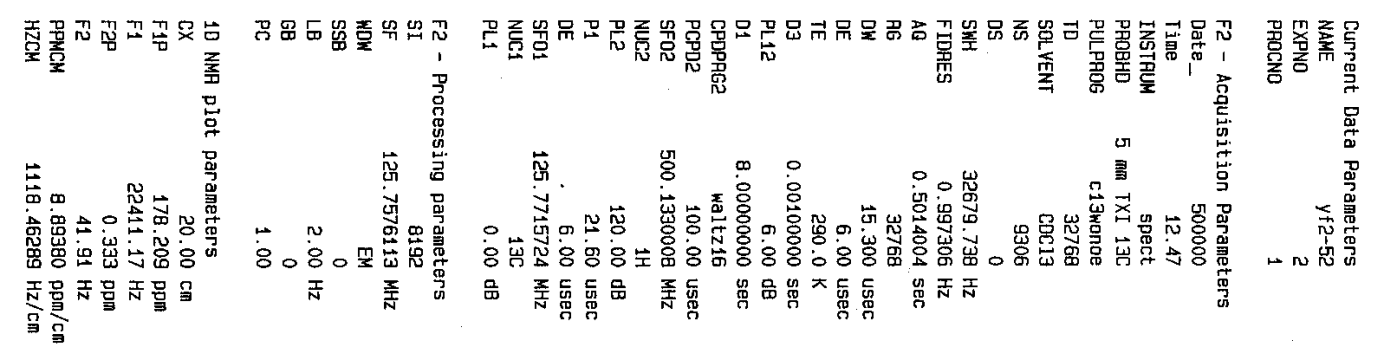

